\title{
The continent ileostomy
}

Citation for published version (APA):

Go, P. M. N. Y. H. (1986). The continent ileostomy. [Doctoral Thesis, Maastricht University]. Rijksuniversiteit Limburg. https://doi.org/10.26481/dis.19861031pg

Document status and date:

Published: 01/01/1986

DOI:

10.26481/dis.19861031pg

Document Version:

Publisher's PDF, also known as Version of record

\section{Please check the document version of this publication:}

- A submitted manuscript is the version of the article upon submission and before peer-review. There can be important differences between the submitted version and the official published version of record.

People interested in the research are advised to contact the author for the final version of the publication, or visit the DOI to the publisher's website.

- The final author version and the galley proof are versions of the publication after peer review.

- The final published version features the final layout of the paper including the volume, issue and page numbers.

Link to publication

\footnotetext{
General rights rights.

- You may freely distribute the URL identifying the publication in the public portal. please follow below link for the End User Agreement:

www.umlib.nl/taverne-license

Take down policy

If you believe that this document breaches copyright please contact us at:

repository@maastrichtuniversity.nl

providing details and we will investigate your claim.
}

Copyright and moral rights for the publications made accessible in the public portal are retained by the authors and/or other copyright owners and it is a condition of accessing publications that users recognise and abide by the legal requirements associated with these

- Users may download and print one copy of any publication from the public portal for the purpose of private study or research.

- You may not further distribute the material or use it for any profit-making activity or commercial gain

If the publication is distributed under the terms of Article $25 \mathrm{fa}$ of the Dutch Copyright Act, indicated by the "Taverne" license above, 


\section{The Continent Ileostomy}

\section{PROEFSCHRIFT}

ter verkrijging van de graad van doctor in de geneeskunde aan de Rijksuniversiteit Limburg te Maastricht, op gezag van de Rector Magnificus, Prof. Dr F.I.M. Bonke, volgens het besluit van het College van Dekanen, in het openbaar te verdedigen op 31 oktober 1986. des namiddags om eén uur dertig

door

Petrus Michaël Nicolaas Yung Han Go geboren te Groningen 
Promotor: Prof. Dr JM. Greep

Co-promotores: Prof. Dr N.G. Kock

DrJ. Lens

Referenten: Prof. Dr F.T. Bosman

Prof. Dr P.J. Brombacher

Prof. Dr G.N.J. Tytgat

\section{CIP-DATA KONINKLIJKE BIBLIOTHEEK, DEN HAAG}

Go, Petrus Michael Nicolaas Yung Han

The continent ileostomy / Petrus Michael Nicolaas Yung Han Go;

[ill. by the author]. - [S.I.: s.n.] (Aalsmeer: Mur-Kostverloren). - Ill. Thesis Maastricht.

- With ref.

ISBN $90-6827-015-X$ bound

SISO 605.8 UDC 617.5:611.34

Subject heading: ileostomy.

\section{ISBN $90-6827-015-X$}

copyright 1986

drukkerij/uitgeverij Mur-Kostverloren b.v.,

Aalsmeer, Nederland

Niets uit deze publikatie mag worden verveelvoudigd en/of openbaar gemaakt door middel van druk, fotocopie, microfilm of op welke andere wijze ook, zonder voorafgaande schriftelijke toestemming van de uitgever.

No part of this book may be reprocuced in any form by print, photoprint, microfilm or any other means without written permission from the publisher. 


\section{CONTENTS}

1 Preface

1.1. Introduction

1.2. Purpose and design of the study

1.3. Nomenclature

1.4. What does quality of life mean?

\section{PART I : SURVEY OF LITERATURE}

\section{Conventional illeostomy}

2.1. History

2.2. Indications

2.3. Technique of traditional operation

2.4. Complications

2.4.1. Metabolic complications

2.4.1.1. Minerals

2.4.1.2. Vitamins

2.4.1.3. Urinary stones

2.4.1.4. Gallstones

2.4.2. Mechanical complications

2.4.2.1. Obstruction

2.4.2.2. Recession

2.4.2.3. Prolapse

2.4.2.4. Fistula

2.4.3. Psychosocial complications

3 Alternatives to conventional ileostomy

3.1. Introduction 23

3.2. Alternative ileostomy valve constructions 23

3.3. Ileorectal anastomosis 26

3.4. Ileoanal anastomosis 27

4 Continent ileostomy

4.1. Theoretic consideration 31

4.2. Development of technique $\quad 31$

4.2.1. The reservoir 31

4.2.2. The outlet 32

4.2.2.1. Antiperistaltic outlet 33

4.2.2.2. Isoperistallic outlet 34

4.2.2.3. Outlet with a "nipple" 34 
4.3. Biological consequences 40

4.3.1. Bacteriology $\quad 40$

4.3.2. Morphology $\quad 40$

4.3.3. Absorption 40

4.4. Indications and contra-indications 41

4.5. Technique of operation 43

4.6. Results 43

4.7. Complications 44

4.8. Quality of life 46

\section{PART II : OWN INVESTIGATIONS}

$5 \quad$ Epidemiological survey

5.1. Introduction 49

5.2. Descriptive epidemiological survey of ileostomy patients 49 in the Netherlands

5.3. Number of patients eligible for a continent ileostomy 53

6 Experiences with the continent ileostomy

6.1. Introduction 55

6.2. Indications 56

6.3. Technique of operation 56

6.4. Postoperative management 62

6.5. Results 64

6.6. Complications 65

6.7. Costs analysis $\quad 68$

7 Clinical investigations of the continent ileostomy

$\begin{array}{ll}7.1 . & \text { Introduction }\end{array}$

$\begin{array}{ll}\text { 7.2. } & \text { Bacteriological investigation } \\ 7.2 . & 73\end{array}$

$\begin{array}{ll}7.2 .1 . & \text { Introduction } \\ 7.2 . & 73\end{array}$

$\begin{array}{ll}\text { 7.2.2. Methods } & 73\end{array}$

$\begin{array}{ll}\text { 7.2.3. Results } & 74 \\ 7.2 .4 . & \text { Discussion }\end{array}$

7.2.4. Discussion 76

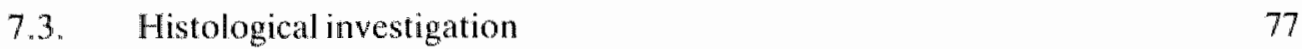

$\begin{array}{ll}\text { 7.3.1. Introduction } & 77\end{array}$

7.3.2. Methods 77

$\begin{array}{ll}\text { 7.3.3. Results } & 78\end{array}$

7.3.4. Discussion $\quad 81$

7.4. Bile acid investigation $\quad 82$

7.4.1. Introduction $\quad 82$

7.4.2. Methods $\quad 83$

7.4.3. Results

7.4.4. Discussion $\quad 89$ 
7.5. Nipple pressure measurements

7.5.1. Introduction

7.5.2. Methods

7.5.3. Results

7.5.4. Discussion

7.6. Psychosocial aspects

7.6.1. Introduction

7.6.2. Report of interviews

7.6.3. Discussion

Summary and conclusions

Samenvatting en conclusies

References

Curriculum vitae 


\section{CHAPTER 1}

\section{PREFACE}

\subsection{Introduction}

This study deals with a special type of ileostomy: the continent ileostomy. In 1969 this operation was introduced by Nils Kock, from Götenborg, Sweden ${ }^{* 3}$. He reported the first five patients who obtained an ileostomy which would make wearing external stoma appliances superfluous. Although the procedure was subject to several changes this continent ileostomy has found worldwide acceptance.

The continent ileostomy consists of an intra-abdominal reservoir and an outlet constructed from the distal part of the ileum. In approximately $95 \%$ of the cases control of small bowel effluent and gas is achieved without devices and external bags. A new dimension to such patients' lives is created and having a continent ileostomy improves the quality of their lives.

In 1982 this operation was introduced by Nils Kock in the "De Wever" Hospital in Heerlen. He visited this hospital twice to teach the construction of continent ileostomy. One of the consultant surgeons (J.L.) propagated the continent ileostomy in the Netherlands. The number of continent ileostomy operations is steadily increasing especially because of the verbal publicity by people with such a continent ileostomy. Until now 30 consecutive patients have been operated on and were extensively studied.

\subsection{Purpose and design of the study}

The purpose of this study is to prove that the continent ileostomy is a better alternative than a conventional ileostomy, as it improves the quality of life without causing major side effects.

By describing the procedure and reporting the results, this new technique might become popular among general practitioners, internists, gastroenterologists and surgeons, so that more patients may benefit from this operation.

The studly consists of two parts.

The first part is a literature survey. The conventional ileostomy and a number of methods to regain or to achieve continence after proctocolectomy will be discussed, with emphasis on the continent ileostomy. The latter procedure will be described in detail and results and complications of this procedure will be reviewed.

The second part consists of own investigations. This part begins with an epidemiological survey concerning ileostomy patients in the Netherlands. The number of patients who are considered eligible for the continent ileostomy will be assessed.

Subsequently, the results of the continent ileostomy operation at the "De Wever" Hospital will be presented. Studies of the biological consequences of this operation will be described. These include the microbial flora in the reservoir, the mucosal histology of the reservoir and the metabolism of bile acids in the reservoir. Nipple valve pressures were recorded. Psychosocial aspects of a continent ileostomy will be highlighted in a number of patients and compared with a conventional ileostomy. 


\subsection{Nomenclature}

In this monograph many medical terms will be used. These terms generally represent combinations of descriptive terms derived from Greek and Latin that are combined to form a kind of verbal shorthand. Some terms and definitions will be explained in order to avoid any misunderstanding.

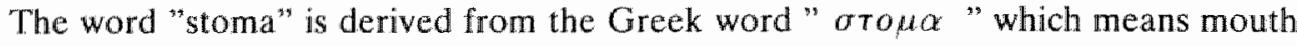
or opening.

A permanent opening, or one that remains open after surgery, is referred to as an ostomy. Ostomies usually provide long term drainage of a hollow organ. A stoma derived from the ileum is called an ileostomy.

An ileostomy can be temporary, that is for several weeks or months, or permanent, to last a patient"s lifetime.

The permanent ileostomy used following removal of the colon and rectum represents the most distal portion of the small intestines and serves as an abdominal anus.

An ileostomy applied by simply bringing out the distal part of the ileum mostly according to the technique advocated by Brooke ${ }^{17}$ will be called a conventional ileostomy. This term is used in contrast with a continent ileostomy. The continent ileostomy consists of two parts : a reservoir or a pouch in which the ileum effluent is collected and an outlet. The adjective "continent" refers to a valvular mechanism of the outlet which controls the outflow of ileum effluent and intestinal gas. The intussuscepted small bowel of the valve projecting into the reservoir is called the nipple ${ }^{84}$.

In this monograph the term continent ileostomy refers to the procedure advocated by Kock ${ }^{86}$ also called Kock's ileostomy or Kock's continent ileostomy.

\subsection{What does quality of life mean?}

This philosophical question will be answered in almost as many different ways as the numbers of persons asked. Some general concepts can be outlined, for example a status of wealth, a prominent position, intellectual abilities, physical or spiritual capacities.

When someone experiences a severe illness, is handicapped or disabled all the above factors will be inferior to a good health. Persons with an ileostomy have a disability. During childhood, learning bowel and bladder control was paid great attention to. When failure of control occurred, one was ashamed and sometimes even punished. Suddenly, in one operation, such mastery is taken away from a person. He must now cope with an uncontrollable anus on his abdomen. Besides the fear of the operation and the bowel disease new difficulties come up. "Shall I smell?", "Will others think I am dirty?", "Shall I be repulsive to my partner, family and friends?".

The initial experience is comparable to the painful process of bereavement. A person will have to go through a period of mourning with the following stages : denial, anger or depression, despair and finally acceptance, if this ever does occur. By providing emotional support to the patient and teaching him and his partner, if any, the mechanisms of stoma care, the process of accepting the illeostomy will be stimulated. 
In order to control the discharge of the small bowel effluent, gas or liquid, Nils Kock worked out the idea of constructing a continent ileostomy so that external appliances would be redundant.

If the operation is successful the disability of an anus on the abdomen remains, but the ability to control it without the stigma of externally visible appliances improves the quality of life for a person with an ileostomy. 
PART I

SURVEY OF LITERATURE 


\section{CHAPTER 2}

\section{CONVENTIONAL ILEOSTOMY}

\subsection{History}

In 1878 Baum, a German surgeon from Danzig, performed an ileostomy operation, which is considered to be the first ileostomy operation. He performed this on a 34 years old railway employee with an obstructing cancer of the ascending colon ${ }^{6}$.

In 1913 Brown $^{20}$ advocated the use of an end ileostomy to put the colon at complete physiological rest in the treatment of ulcerative colitis. The first ileostomies were performed by drawing the cut end of the terminal ileum out through the laparotomy incision. Many complications of the laparotomy wound and of the ileostomy itself arose. A separate "stab-wound" exit for the ileostomy gave clear advantages"

The technique of constructing an ileostomy and its aftercare underwent significant changes during the last decades. Originally the method employed was to leave the terminal $3-5 \mathrm{~cm}$ of ileum projecting beyond the abdominal wall with a glass tube or a rubber catheter tied in to it. The stoma was encircled with dry gauze, to which it became rapidly adherent and which prevented the stoma from prolapsing to the exterior (figure 2.1.). After 5 days the tube or catheter was removed and an ileostomy bag was applied. After 2 weeks the exposed ileal surface was gradually covered with granulation tissue. Ultimately this tissue was converted into fibrous tissue. By this process of "maturation" the ileal mucosa was subsequently everted and drawn down to the skin.

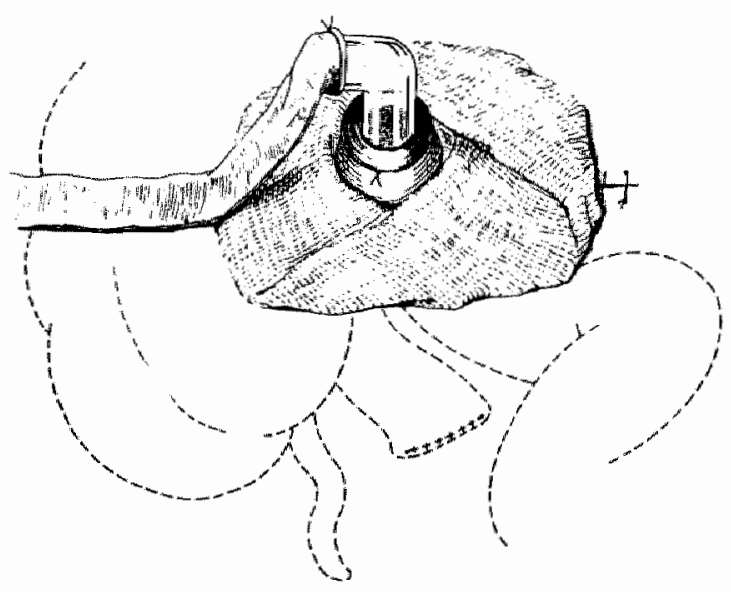

Figure 2.1.

The glass tube terminates in that portion of ileum which is external to the abdominal wall (From Warren ${ }^{155}$ ). 
Unfortunately, this fibrous ring was very liable to undergo narrowing, and in this way producing a troublesome stenosis at skin level. Although complete obstruction rarely occurred Warren and McKittrick ${ }^{155}$ saw partial obstruction in $62 \%$ of their patients. In an attempt to shorten the healing time of the lleostomy and to minimize the skin problems, Dragstedt ${ }^{37}$ wrapped a split-thickness skin graft around the exteriorized ileum and sutured it to the skin around the stoma (figure 2.2.). This method was abandoned because subdermal fibrosis and contraction with partial obstruction was seen in half of the patients ${ }^{31}$.
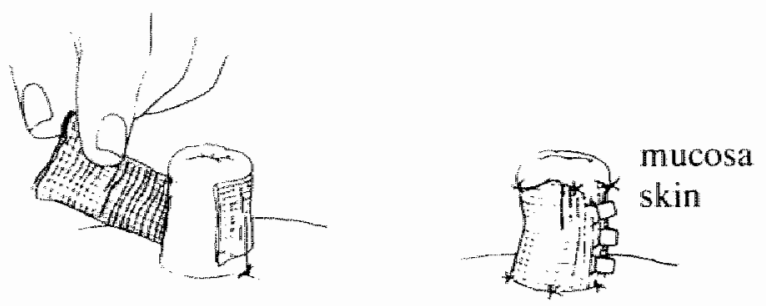

Figure 2.2.

Ileostomy with split-thickness skin graft wrapped around the exteriorized ileum (From Turnbull $\left.{ }^{167}\right)$.

In an effort to shorten the "maturation" time and to prevent ileostomy dysfunction Turnbull ${ }^{1{ }^{47}}$ suggested to trim the stoma on the seventh postoperative day in such a way as to leave the mucosa long enough to evert part of the way down the edges of the ileostomy (figure 2.3.).
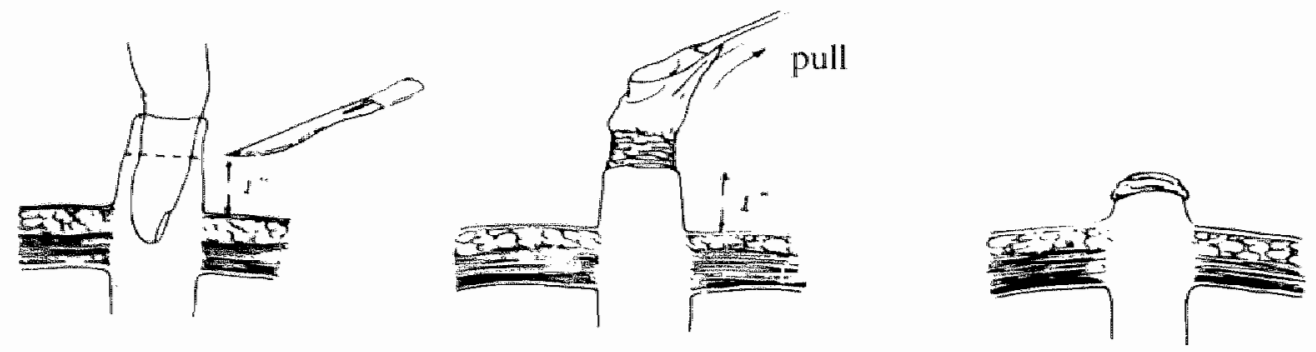

Figure 2.3.

lleostomy trimmed in such a way to leave the mucosa long enough to evert part of the way down the edges of the ileostomy (From Turnbull ${ }^{147}$ ). 
It was Brooke ${ }^{17}$, who introduced and advocated the principle of immediate muco-cutaneous suture in constructing ileostomies. This procedure included everting the terminal ileum on itself after pulling it through a separate stab wound in the abdominal wall (figure 2.4.). The surfaces were brought in apposition and the mucosa was exteriorized. The cut end of the bowel mucosa was then "immediately sutured to the skin.
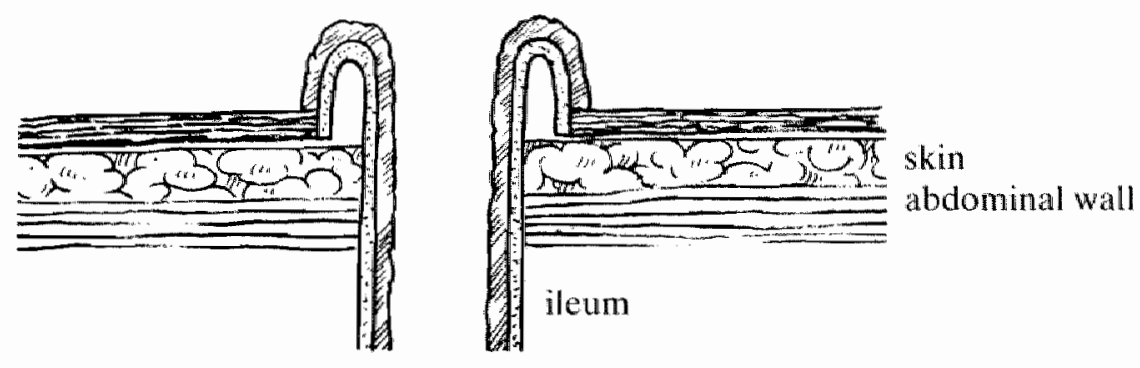

Figure 2.4

Ileostomy with everted end : the Brooke ileostomy.

The development of ileostomy appliances contributed to the success of the stoma care. In the early days simple bags and boxes were used. Dermatitis and leakage were common, making life with an ileostomy hardly bearable.

In 1936 Koenig and Rutzen created an appliance cemented to the skin. Protection from the corrosive action of small intestine content was achieved. This watertight and leakproof arrangement for collecting ileostomy effluent increases the range of the patients activities and enjoyment of life. By introducing new adhesive appliances which give better protection of leakage and less skin irritation, ileostomy patients nowadays can live an almost normal life for the outside world.

\subsection{Indications}

The major indication for terminal or "end" ileostomy is inflammatory bowel disease, usually idiopathic ulcerative colitis or Crohn's disease involving the large intestine. Occasionally it may be advisable in patients with polyposis coli or in those with multiple malignant or premalignant tumors in the large intestine. Megacolon, mostly caused by $M$. Hirschprung affecting the whole large bowel can be an indication for proctocolectomy, which results in an "end" ileostomy.

\subsection{Technique of traditional operation}

The procedure of choice for constructing a terminal ileostomy is the Brooke ileostomy. The exact site for the ileostomy will be chosen preoperatively, so that there is an area of flat smooth skin all around it, to which the jleostomy bag may be securely stuck (figure 2.5.A). A "button" of skin and subcutaneous tissue, 2.5 to $3 \mathrm{~cm}$ in diameter is 
removed. The anterior rectus sheath is divided with a cruciate incision and the muscle is separated bluntly. The posterior sheath and peritoneum are incised vertically. When the incision is complete, two fingers should pass snugly through the opening. It is important that, during tract construction, all the layers of the abdominal wall are aligned as they will be when the abdomen is closed.

The ileum is passed through the abdominal wall and gently positioned, making sure that an adequate length is delivered. A length of $6-8 \mathrm{~cm}$ ileum should be projected beyond the abdominal skin in order to produce a final protrusion of 3 to $4 \mathrm{~cm}$ everted illeostomy bud. To avoid internal hernia and volvulus of the small intestine the tube of bowel and its related mesentery is fixed to the abdominal wall (figure 2.5.B).

Most surgeons prefer to suture the anterior rectus sheath to the seromuscular bowel wall from the outside. It should be emphasized that the bites of the ileal wall should be superficial and may not penetrate deeper than the muscle coat, for otherwise fistulas may occur. The bowel end will be everted by suturing the end of the ileum to the skin (figure 2.5.C).

A preselected stoma appliance is applied. The appliance should be large enough to allow some edema of the stoma. At the same time it should provide maximum skin protection.
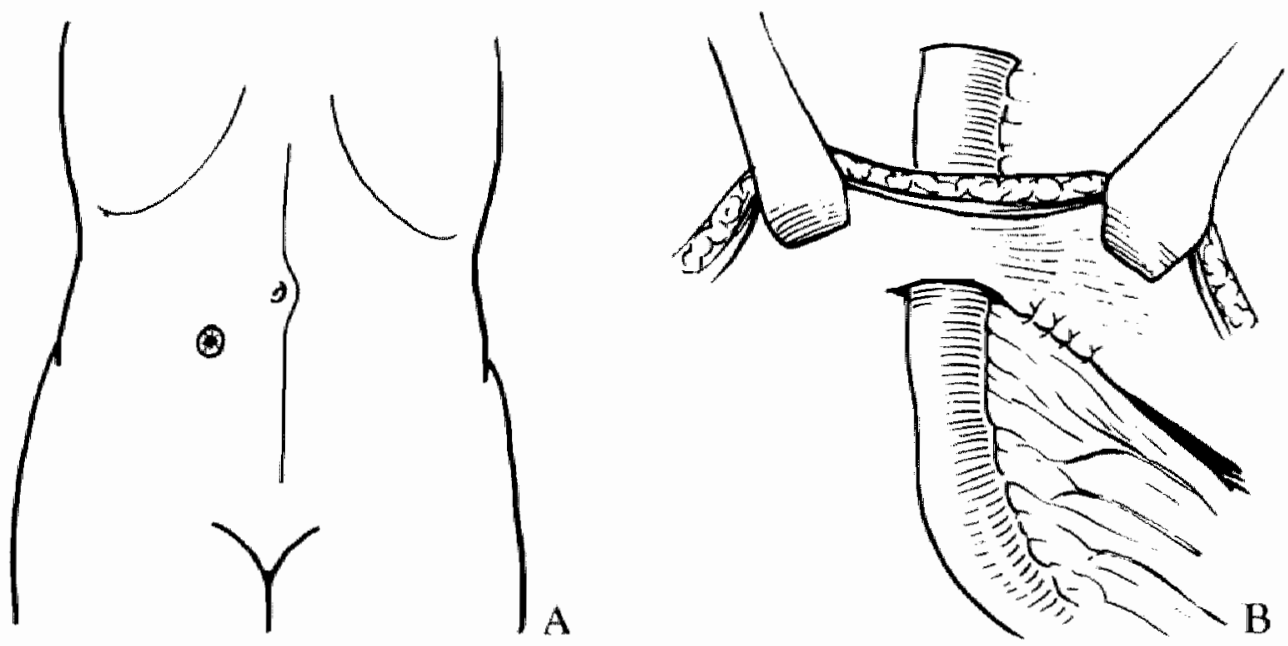

Figure 2.5.

Technique of the traditional operation.

A : Ileostomy site.

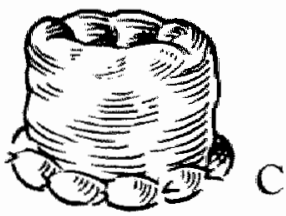

B : Fixation of the mesentery to the abdominal wall.

C : Eversion of stoma (completed). 


\subsection{Complications}

Most emphasis is put on somatic complications as they are easily recognizable and likely to be solved by medical treatment.

Difficult to recognize and hard to treat are social and psychological problems, here referred to as "psychosocial" complications, related to the stoma. The importance of these problems is too often underestimated or even ignored by the patients themselves. The most common complications will be discussed below:

2.4.1. Metabolic complications

2.4.2. Mechanical complications

2.4.3. Psychosocial complications

\subsubsection{Metabolic complications}

To obtain a proper understanding of the metabolic complications that may occur in ileostomy patients it will be necessary to understand some aspects of adaptation that take place after the construction of an ileostomy. In the postoperative period the ileostomy efflux will be one or two liters per day. When the ileostomy is established the daily output will be approximately $500-600 \mathrm{ml}$ per day ${ }^{18}$. The normal excretion of urine in the ileostomy patient is about $800 \mathrm{ml}$ per day, whereas it is $1,500 \mathrm{ml}$ per day in a healthy person. With normal nutrition there will be no apparent clinical deficiencies. However, if the volume of ileal excretion increases for some reason, sodium, water and magnesium depletion may occur. In clinical practice the increased output is generally related to partial intestinal obstruction, recurrence of Crohn's disease, intraabdominal sepsis or resection of the terminal ileum.

\subsubsection{Minerals}

A well functioning ileostomy excretes about $60 \mathrm{mmol}$ of sodium and $500 \mathrm{ml}$ of water each day. These values are 2 to 3 times those found in faeces of normal persons. This might be compensated by increased dietary intake and decreased renal output. Aldosterone might play a role in this latter mechanism ${ }^{4 x_{*} 78}$. It seems that patients with an lleostomy regain a new equilibrium in sodium and water balance 25,48 . No water depletion or reduction of body cell mass was found ${ }^{116}$.

Primary potassium depletion is uncommon in the ileostomy patient. When it occurs it is usually secondary to sodium depletion, which results in increased renal losses of potassium.

Magnesium depletion is rare but should always be remembered if high output is present.

Calcium deficiency is not common, as losses from an ileostomy are very low, even lower than in normal faeces ${ }^{79}$.

Kennedy et al. " found a mild degree of iron deficiency which was correctable by oral supplements. 


\subsubsection{Vitamins}

Vitamin supplements are not normally required in the established stoma patient, if less than $15 \mathrm{~cm}$ of illeum is resected. Surprisingly, Kennedy ${ }^{77}$ found that the absorption of vitamin $B_{12}$ is enhanced in ileostomy patients who had had ulcerative colitis. On the other hand $\mathrm{Hult}_{\text {ten }}{ }^{67}$ reported a borderline value for vitamin $\mathrm{B}_{12}$ after colectomy and ileostomy. This was due to reduced vitamin $B_{12}$ absorption, probably caused by an imbalance of the micro flora in the small bowel. If a considerable length of distal ileum is removed, as in Crohn's disease, vitamin $B_{12}$ and folic acid ought to be supplied.

\subsubsection{Urinary stones}

The prevalence of urinary stones in ileostomy patients is about $8 \%{ }^{109,132}$ compared with a maximum of $3.8 \%$ in the general population. Uric acid stones usually comprise less than $10 \%$ of all stones, but make up $60 \%$ of stones found in patients with an ileostomy. Compared with normal control subjects ileostomy patients have significantly lower urinary $\mathrm{pH}$ and volume, higher concentrations of calcium, oxalate. In practical terms, a patient with a well-functioning ileostomy has an increased risk of forming uric acid and calcium stones ${ }^{155}$.

\subsubsection{Gallstones}

In a large scale cholecystographic study of a group of ileostomy patients, the incidence of patients with gallstones, usually asymptomatic, was three times the incidence that might have been expected in a population of the same age and sex. Ileum resection of more than $10 \mathrm{~cm}$ increases the frequency of cholelithiasis significantly ${ }^{65}$.

Loss of the terminal ileum due to disease or surgical resection is now known to have an adverse effect on the enterohepatic circulation of bile acids, with a consequence of predisposition to the development of gallstones ${ }^{18}$.

With sonographic examinations Kurchin et al. ${ }^{95}$ found cholelithiasis in $23 \%$ of patients with an ileostomy, who were operated on for inflammatory bowel disease. Among women over 50 years old $64 \%$ had gallstones. He therefore recommended gallbladder imaging as part of the preoperative examination and postoperative follow-up of ileostomy patients. Moreover, prophylactic cholecystectomy might be carefully considered in the elderly female patient with inflammatory bowel disease at the time of proctocolectomy.

\subsubsection{Mechanical complications}

Mechanical complications and complications related to unsatisfactory siting of an ileostomy are the main reasons for reoperations. The reoperation rate for ileostomy related complications varies from $11 \%{ }^{129}$ to $41 \%{ }^{19}$. Most large series report a reoperation rate of $25 \% \%_{12,10 \%, 132}$.

The most common mechanical complications are obstruction, recession, prolapse and fistula. Less frequent are stomal or peristomal ulceration, granuloma formation and 
herniation. Table 2.1. gives an illustration of the reason for reoperations in some studies.

Table 2.1 .

Number of reoperations for several reasons after obtaining a conventional ileostomy.

\begin{tabular}{lcccc}
\hline & Goligher & Failles $^{52}$ & Roy $^{13}$ & Goldblatt \\
\hline Obstruction & not given & 6 & 14 & 12 \\
Recession & 12 & 15 & 7 & 10 \\
Prolapse & 3 & 4 & 7 & 10 \\
Fistula & 3 & 6 & 12 & 12 \\
Herniation & not given & 1 & 3 & 1 \\
Unsatisfactory siting & 10 & 3 & not given & 7 \\
* obstruction due to intestinal adhesions not included & & \\
\hline
\end{tabular}

\subsubsection{Obstruction}

Some signs of obstructive symptoms in the immediately postoperative period are common. Later on, obstruction may be due to a true stenosis or to a food bolus. The true stenosis can be located at skin level, at the level of the abdominal fascia or in the abdomen due to bands of adhesions. Seven to nine per cent of the illeostomy patients who suffer from the latter problem need adhesiolysis by laparotomy at a certain period in their lives 132,129 .

Skin level stenosis at the muco-cutaneous junction can be related to local sepsis or ischemia or recurrent Crohn's disease. If surgery is indicated a small amount of skin should be excised and immediate resuture of mucosa to skin should be carried out.

The most common cause of obstruction at the level of the abdominal fascia is a collection of food debris. Insufficiently chewed oranges, grapefruits, thubarb, pineapples or currants are often to blame. These swell in the intestine and obstruct the bowel just proximal to the stoma. A little saline washout introduced by a small soft catheter can usually re-establish the stoma function.

\subsubsection{Recession}

Recession is usually due to the gap through the abdominal wall being too big. Failure of adhesion between the two layers of the intussuscepted stoma is secondary to this, as peristalsis enables the layers to move on one other without pressure on the stoma base where it passes through the abdominal wall. Recession initially occurs at night only when the patient is supine, and is likely to cause leakage in bed, which is a great distress to the patient. It can also occur during pregnancy but usually reverts to normal after dellivery.

If stoma therapy is unsuccessful, an operation should not be delayed. 


\subsubsection{Prollapse}

Prolapse of the ileostomy is not very common and is probably due to inadequate fixation of the mesentery within the abdomen. Often it can be easily corrected simply by detaching the ileum at the muco-cutaneous junction, unravelling it, drawing the mesentery up taut, amputating at the appropriate length and re-establishing the stoma. If the mesentery has been completely detached and an excessive length of ileum can be withdrawn through the stoma site, then the abdomen must be reopened, the mesentery reattached and the stoma reconstructed.

Sometimes the orifice of the abdominal wall is too large. This usually occurs when the intestine is edematous at the time of constructing the stoma and has shrunk since. Prolapse may alternate with periods of recession at night. In this case it is unadvisable to try to narrow the hole through the abdominal wall. It is better to resite the ileostomy elsewhere.

\subsubsection{Fistula}

Fistula, stoma ulceration and granuloma around the base of the stoma may imply recurrent disease, such as Crohn's disease.

Fistula can be at muco-cutaneous level or below skin level. Apart from recurrent disease, an ill-fitting or misapplied appliance that exerts pressure upon the stoma can lead to ulceration and fistulation. A fistula below skin level can be due to inaccurate stitching of the serosal surface of the ileum to the fascia, where a too generous bite has picked up mucosa. In such a case stoma reconstruction with laparotomy is very often required.

Granulomas may suggest a fistula, probably because of persistent irritation. Stitches retained too long will cause granulomas. These granulomas usually respond to cauterization with silver nitrate or diathermy. Of course, local infection sometimes caused by fungi must be excluded.

A rare case of soreness at the base of the stoma is caused by an excessive angulation of the stoma downward. A "wet" area is present at the muco-cutaneous junction. This is treated by excision and resuturing the area.

\subsubsection{Herniation}

Herniation is a complication occurring at later stage. If the abdominal pressure raises, peristoma bulging occurs. This may lead to leakage and skin problems, for herniation interferes with the firm retention of the ileostomy appliance.

Herniation is usually seen when the stoma is brought out through laparotomy incision or when the stoma site is excessively large. When the stoma is correctly sited through the rectus abdominis muscle, herniation seldom occurs. The only satisfactory treatment for this condition is to re-site the ileostomy. 


\subsubsection{Psychosocial complications}

This group of complications seldom needs surgical intervention. Therefore, by most physicians these are greatly underestimated. These problems, however, affect the quality of life of the ileostomy patients and have often great influence on their personat and social activities. If an inquiry is set up 70-90\% will answer that they are in good general health. But if in the same inquiry people are interviewed about problems in respect of skin irritation, stoma appliances or odour, a relatively high percentage of problems will be found. Table 2.2. shows this by representing three large studies.

Table 2.2.

Percentage of other ileostomy related problems.

number of patients

\begin{tabular}{ccc} 
Roy $^{132}$ & Morowitz $^{\text {tw9 }}$ & McLeod $^{103}$ \\
\hline 497 & 1803 & 322 \\
$35 \%$ & $56 \%$ & $49 \%$ \\
$16 \%$ & $29 \%$ & $29 \%$ \\
not given & $23 \%$ & $42 \%$ \\
\hline
\end{tabular}

Return to work following an ileostomy does not seem to be a major problem. In a large study the experiences of 1033 persons in Great Britain and Ireland were analysed ${ }^{157}$. In 5 per cent problems regarding finding a job or resumption of employment are reported. Two studies mentioned previously ${ }^{1 / 3,109}$ affirm this.

Approximately $95 \%$ of the persons with an ileostomy indicated that they were employed or in active duty.

Scarce information is avalable about the intimate feelings of ileostomy patients such as altered body image, feelings of shame, depressive moods and social isolation. Relatively much attention is focused on the aspects of sexual functioning of leostomy patients $19.27 .52,77.131$. The presence of an ileostomy will be experienced mostly during the intimate contact of sexual activity both for the ileostomy patient as well as for hisher partner. Brouillette ${ }^{19}$ found that $50 \%$ of the women in his survey had had sexual problems since their operation (rectal excision). Rolstad ${ }^{31}$ found that for $46 \%$ of the ileostomy patients sexual intercourse was psychological more burdensome. Appropriate sexual information and guidance preoperatively and a good aftercare postoperatively will certainly reduce these problems ${ }^{52}$. Besides psychological reasons also physical reasons can be mentioned for sexual dysfunction.

As regards women the main cause is discomfort during intercourse or dyspareunia. This might be due to perineal scar or the tethering of the vaginal wall posteriorly after removal of the rectum. Burnham et al.$^{23}$ found some dyspareunia in one-third of women in his survey.

With regard to men physically sexual dysfunction is related to partial or complete erectile impotence. This occurs merely after removal of the rectum predominantly in men over the age of 45 . Burnham et al. ${ }^{23}$ found in 88 men up to the age of 45 one man who developed complete erectile impotence, and 17 men with partial dysfunction. Over this age 5 out of 30 men developed complete, while 11 men developed partial erectille impotence. 


\section{ALTERNATIVES TO CONVENTIONAL ILEOSTOMY}

\subsection{Introduction}

Until recently the vast majority of patients with ulcerative colitis or polyposis coli requiring proctocolectomy were provided with a conventional Brooke ileostomy, Advances in the technical construction of ileostomies and in the development of enterostomal devices have resulted in wider acceptance of permanent ileostomy. Nevertheless, considerable resistance still exists to create a permanent ileostomy especially in the young age group. In the past two decades, several alternatives to this conventional approach have been assiduously perfected and, in some surgical centres, have been offered to carefully selected patients.

The currently available alternative operations after abdominal colectomy include continent illeostomy and anal sphincter saving operations like ileorectal anastomosis and ileoanal anastomosis with mucosal proctectomy. Until now Kock's continent ileostomy is the most successful procedure to control the ileum effluent from an ileostomy. A close look will be taken at this in chapter 4 .

Other procedures were attempted to obtain continence from an ileostony, although with less success. Since the ileorectal and the ileoanal anastomosis preserve the normal physiology of defecation, much attention has been given to it.

\subsection{Alternative ileostomy valve constructions}

Since Kock's concept of constructing a continent ileostomy, many attempts have been made to find a procedure to control the effluent of an ileostomy. Most of these constructions are still in animal experiments, only few were applied on humans.

A sphincteroplasty using autologous smooth muscle has been worked out by Schmidt and his staff ${ }^{3}$. Intestinal smooth muscle can be autotransplanted without losing functional and histological integrity. A seromuscular sleeve is wrapped around the distal ileum and put in place as sphincteroplasty above a reservoir.

Orangio et al. $1 \%$ created a valve along the antimesenteric border of the effluent limb of the reservoir. The seromuscular layer is stripped from the mucosal layer for $50 \%$ of the bowel circumference and then excised (B in figure 3.1.A). The remaining seromuscular borders are then sutured to the apex of the pouch and along the antimesenteric border of the afferent limb ( $C$ in figure 3.1.A). In this way a valve is created. Upon distension of the afferent limb and apex of the pouch, the valve closes (figure 3.1.B). Besides constructing an ileostomy valve mechanism from the gut itself, the use of artificial devices to achieve intestinal continence was tested in animal studies. A totally implanted, intermittently inflatable rubber cuff, reservoir and control mechanism were evaluated by Chandler et al. ${ }^{24}$. Fendel et al. ${ }^{45}$ used a porcine aorta valve in the efferent loop of a reservoir to obtain continence (figure 3.2.). A prosthetic valve constructed fine Silastic tubing on the efferent limb of a reservoir was lested by 
Mihranian et al. ting balloon catheter was evaluated by Sanada et al. ${ }^{133}$.
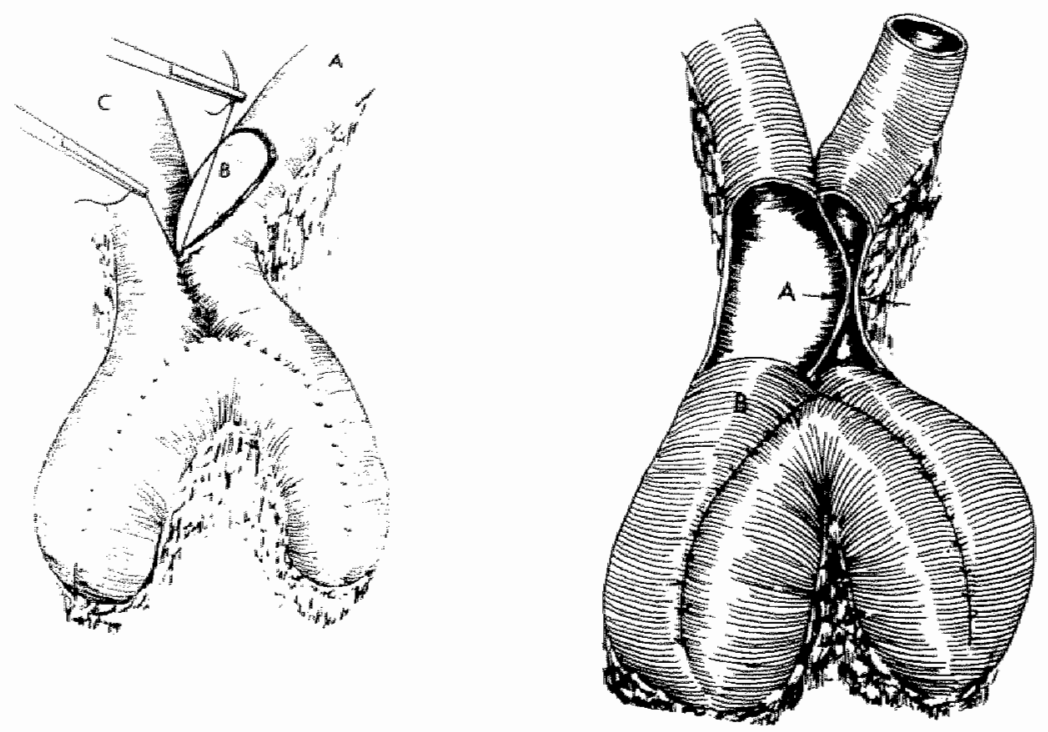

Figure 3.1.

A new type of mucosal valve reconstruction (from Orangio ${ }^{118}$ ). See text for explanation

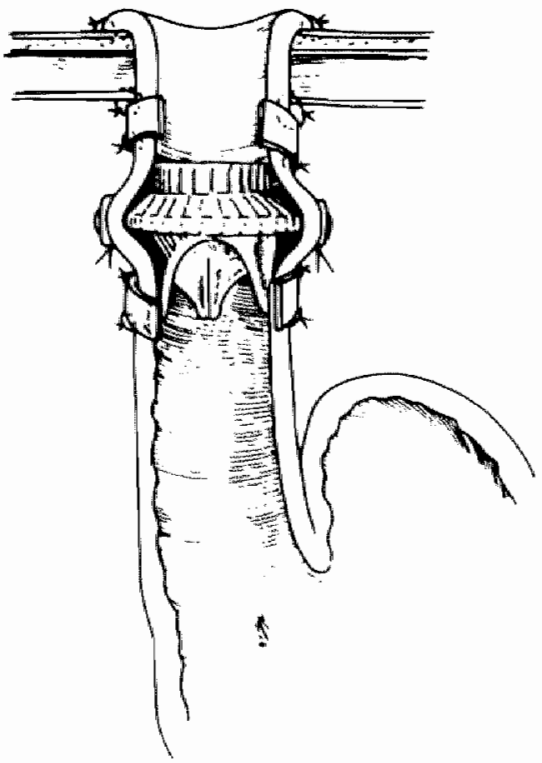

Figure 3.2.

A porcine aortic valve utilized for maintenance of continence (from Fendel ${ }^{45}$ ). 


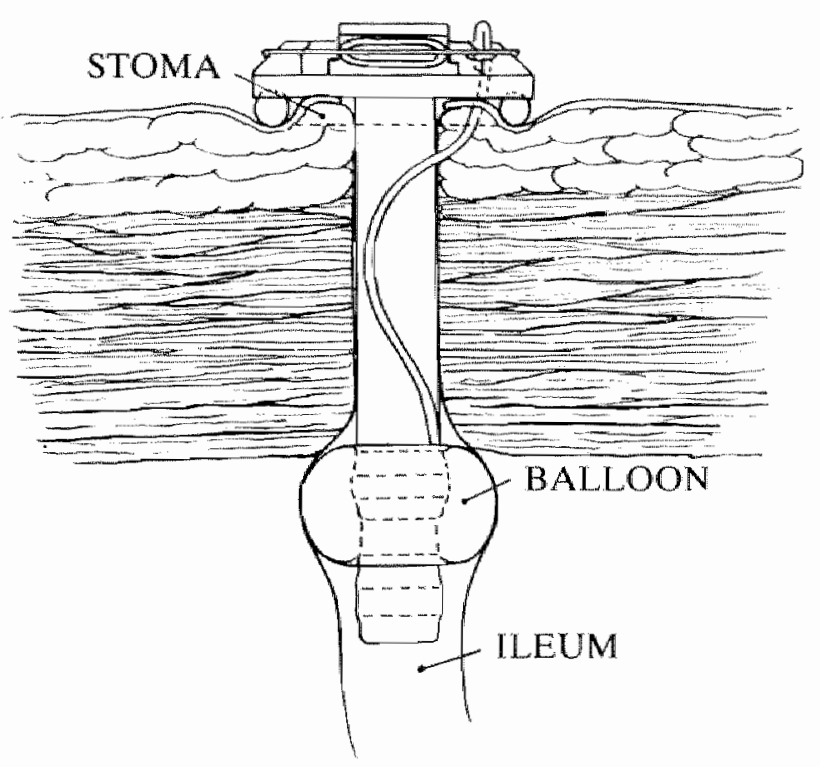

Figure 3.3.

Ileostomy occluding device with inflatable balloon and clasp to occlude outflow, positioned in ileal stoma in abdominal wall (from Pemberton ${ }^{124}$ ).

In 1981 Pemberton et al. ${ }^{124}$ reported the use of an indwelling stomal device to achieve ileostomy continence in dogs. A sillastic tube with a balloon on its end is inserted through an ileostomy, in such away that the balloon rests deeply against the anterior abdominal fascia. The balloon is then inflated and pulled back against the inner aspect of the abdominal wall, and held in place by a retaining disk slipped over the external end of the tube (figure 3.3.). The external portion of the tube is doubly folded and clasped to the top of the disk, thus completely occluding ileal outflow.

After the initial success in dogs the occlusive stomal device was used on humans at the Mayo-clinicl25. An important application is the use of this device in patients who have a failed Kock's ileostomy. The reservoir can still be used, but the slipped or bad functioning valve will be replaced by the occlusive indwelling device. In 50 patients with a failed Kock's continent ileostomy success was achieved in $84 \%$ using the device $^{76}$.

Less success is obtained in patients with a conventional ileostomy, who wish to be continent being poor candidates for a Kock's ileostomy. The device was used in 4 patients with a Brooke ileostomy ${ }^{76}$. Cramps and peristomal soreness occurs because of obstruction of the outlet. A prestomal pouch provides an immediate and readily distensible reservoir, which reduces the discomfort of the obstruction. With prestomal ileal pouch 3 out of 7 patients used the device regularly $y^{76}$. 
The concept of removing the diseased colon and anastomosing the terminal ileum to the upper part of the rectum has been an attractive surgical option. At the same time a segment of diseased rectum remains, which would seem to be tantamount to an invitation to further trouble.

The main proponent of the ileorectal anastomosis over the years has been Aylett, who reported 300 cases of diffuse ulcerative colitis treated by colectomy and ileorectal anastomosis in $1966^{3}$. He reported an overall mortality rate of $5.7 \%$. In $5 \%$ of the patients conversion to conventional ileostomy was necessary because of the development of carcinoma of the rectum, stricture and incontinence. Jagelman et al ${ }^{70}$ questioned 200 patients of the Aylett's group about the results of their operations. About $90 \%$ thought that the surgical treatment was an enormous success.

These results encouraged many surgeons to perform this procedure. Overall results from the literature are listed by Parc et al. ${ }^{121}$. Good results were obtained in $57.6 \%$ of the patients, i.e. having one to four stools a day, need to get up at night only occasionally, and having a normal or nearly normal rectal mucosa. Of the 1,206 patients $14.8 \%$ needed a secondary proctectomy and can, therefore, be classified as failure.

Anastomosis dehiscence after ileorectal anastomosis occurred in $5 \%{ }^{152}$ to $10 \%{ }^{65 t}$ of the cases. If no loop ileostomy was used anastomosis dehiscence appeared to be the major cause of postoperative mortality ${ }^{117}$.

Although the inflammatory disease usually settled down, Parc et al. ${ }^{121}$ found that in $25 \%$ of their patients the process remained active. In approximately $10 \%$ ulcerations remained. A micro-rectum, which caused an increased stool frequency, developed in the remaining $5.5 \%$ of their patients.

Recently Oakley et al. ${ }^{117}$ evaluated functional results of the ileorectal anastomosis. They found that approximately $60 \%$ of their patients had more than 3 bowel movements per day and $10 \%$ even more than six. More than one-third of them required antidiarrhoeal medications, sulfasalazine and even steroids.

In ulcerative colitis it seems, therefore, reasonable to restrict the use of ileorectal anastomosis to patients with relatively mild changes in the rectum without ulcerations, strictures or any significant fibrosis in the rectal wall, which would impair its ellasticity and ability to distend postoperatively to form an effective fecal reservoir.

Colectomy and ileorectal anastomosis is preferably avoided in patients with systemic complications (arthritis, iritis and skin manifestations) which may not resolve completely if any part of the diseased large bowel remains ${ }^{5 R}$.

The cancer risk in patients with ulcerative colitis in the remaining rectum is the major objection to the ileorectal anastomosis. This was the subject of an extensive study by Kewenter ${ }^{* *}$, Baker ${ }^{4}$ and Grundfest ${ }^{\text {th }}$. As shown in figure 3.4. the cumulative risk of developing cancer of the rectum increases as time goes by. These findings suggest that follow up is absolutely necessary in these patients with regular endoscopic examinations to proceed with multiple biopsies.

Colectomy with ileorectal anastomosis can be used in patients with Crohn's disease of the large bowel, which has not affected the rectum. It must be kept in mind that half of these patients will need reoperation for recurrence of Crohn's disease ${ }^{21.152}$. 


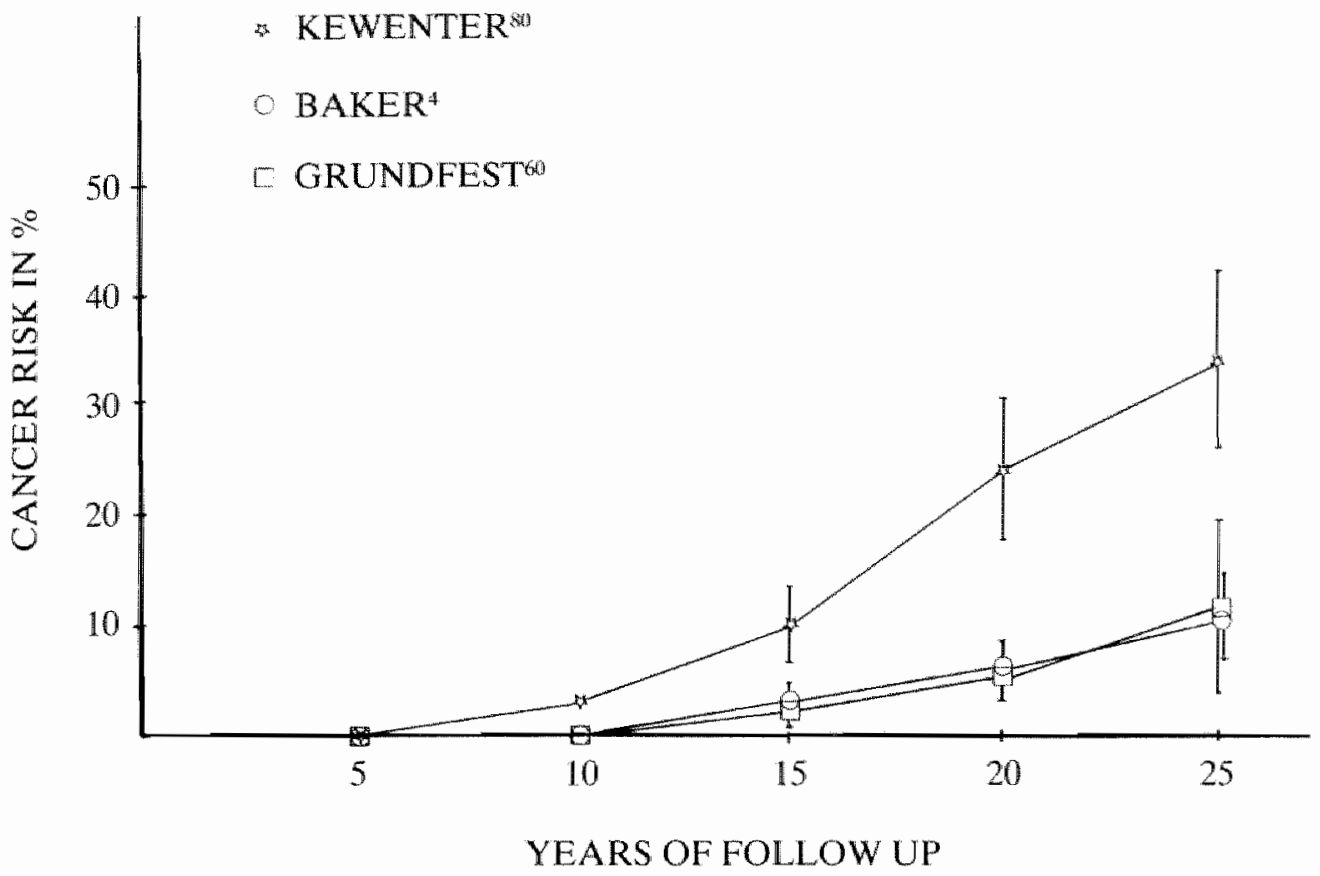

Figure 3.4.

Cumulative risk of developing cancer in ulcerative colitis patients after ileorectal anastomosis after onset of symptoms.

Discussing the exact role of colectomy with ileorectal anastomosis some considerations must be taken into account. As an advantage one can avoid perineal wounds and sexual dysfunction, the physiologic evacuation of the rectum is maintained, while not having a stoma. On the other hand complications may result from a difficult anastomosis to a diseased rectum and it should be discussed which functional results can be achieved and what the ultimate fate of the rectum will be with regard to the persistence or recurrence of inflammatory disease and the development of cancer.

\subsection{Ileoanal anastomosis}

A proctocolectomy that would preserve the function of the anal sphincter is an attractive surgical alternative. Ravitch contributed much to the development of the ileoanal anastomosis procedure. In 1948 he ${ }^{128}$ reported the first two patients who were successfully operated. The rectal mucosa was stripped of from below leaving a rectal muscular cuff above the dentate line. He believed that the nerve endings responsible for rectal sensation rested in the rectal muscular coat, so that even after the excision of the mucosal lining of the lower rectum, the normal sensory mechanism subserving anal continence should be retained. Although Ravitch reported satisfactory functional results, other surgeons found that mostly the adult patients had significant problems with stool frequency and urgency especially during the night. This was so uncomfor- 


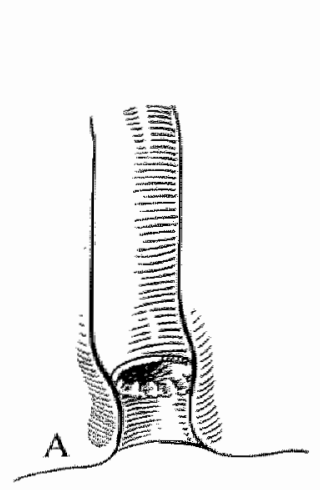

ILEOANAL
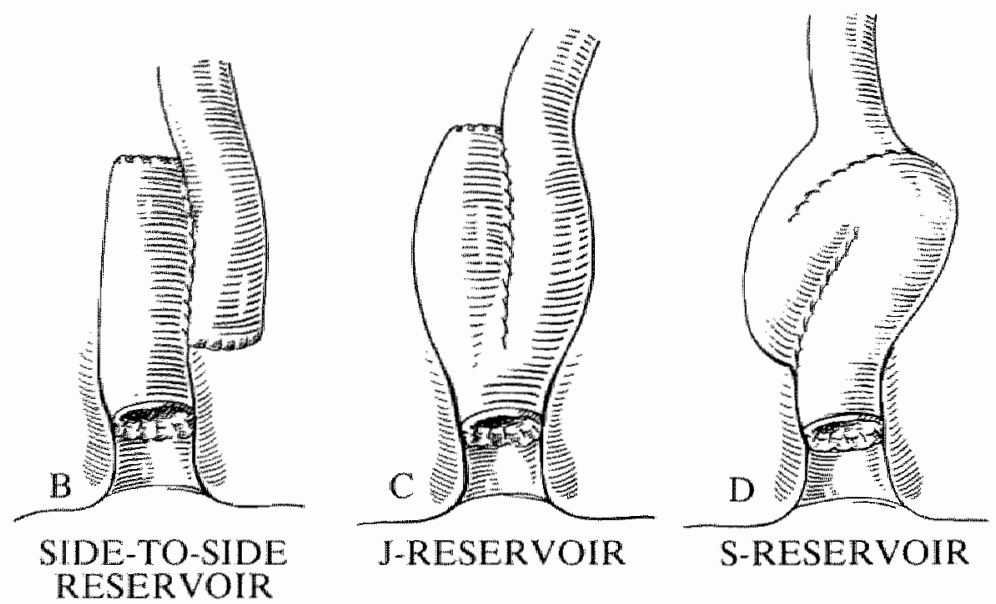

Figure 3.5 .

Four ileoanal anastomosis procedures.
A. Ileoand anastomosis without a reservoir
B. Ileoanal anastomosis with a side-to-side reservoir
C. Ileoanal anastomosis with a $\mathrm{J}$-reservoir.
D. Ileoanal anastomosis with an S-reservoir

table that most of them eventually had an ileostomy performed. Recently, only Telander et al. ${ }^{45}$ have reported their results of the straight ileoanal procedure (see figure $3.5 . \mathrm{A}$ ) in young patients. In $75 \%$ the results were considered good, in spite of the fact that 3 months after closure of the ileostomy the average stool frequency was as high as 10.5 per 24 hours. Stool frequency could be reduced to 6.4 per 24 hours by balloon dilations of the neorectum.

It was in the late nineteen-seventies that the important role of the rectum in maintaining continence was elucidated. As this function was replaced by the distal ileum, a reservoir had to be made from distal ileum. From manometric measurements Heppell et al. fit found that the larger the capacity of the neorectum, the fewer the number of bowel movements per day. Several types of reservoirs were described (see figure 3.5.B,C,D).

The ileoanal anastomosis is indicated in young patients with ulcerative colitis or polyposis coli. These patients should have an intact anal sphincter mechanism. The procedure should be discouraged in patients strongly suspected of having Crohn's disease. Older patients, with poor anal sphincter tone are no suitable candidates. Because of its complex nature and because it is time-consuming, mucosal proctectomy and ileoanal anastomosis should not be performed in critically-ill patients or patients undergoing emergency operations. 
Table 3.1 .

Results and complications of ileoanal anastomosis with the S-reserwoir and the J-reservoir.

\begin{tabular}{|c|c|c|c|c|c|}
\hline Author & Parks ${ }^{123}$ & Wong ${ }^{159}$ & Nicholls & Utsunomiyalso & Dozois ${ }^{35}$ \\
\hline Pouch shape & $\mathrm{S}$ & $\mathrm{S}$ & $\mathrm{S}$ & J & $\mathrm{J}$ \\
\hline Number of patients & 21 & 70 & 68 & 34 & 369 \\
\hline Mean age & 31 & 31 & 33 & 25 & 32 \\
\hline $\begin{array}{r}\text { Continence: day } \\
\text { night }\end{array}$ & $\begin{array}{l}90 \% \\
75 \%\end{array}$ & $\begin{array}{l}94 \% \\
79 \%\end{array}$ & $\begin{array}{l}95 \% \\
71 \%\end{array}$ & $\begin{array}{l}74 \% \\
\text { not given }\end{array}$ & $\begin{array}{l}98 \% \\
95 \%\end{array}$ \\
\hline $\begin{array}{l}\text { Mean stool frequency } \\
\text { per } 24 \text { hours }\end{array}$ & 3,8 & 6 & 3,7 & 4,5 & 7,2 \\
\hline Pelvic sepsis & $14 \%$ & $11 \%$ & $25 \%$ & $31 \%$ & $11 \%$ \\
\hline Anastomotic stricture & not given & $13 \%$ & $10 \%$ & not given & $12 \%$ \\
\hline Pouchitis & $5 \%$ & $27 \%$ & $11 \%$ & $12 \%$ & $7 \%$ \\
\hline Intestinal obstruction & $14 \%$ & $13 \%$ & $15 \%$ & $6 \%$ & $8.5 \%$ \\
\hline
\end{tabular}

Results and complications of ileoanal anastomosis with the S-reservoir of Parks ${ }^{122}$ and with the J-pouch first proposed by Utsunomiya ${ }^{149}$ are shown in table 3.1 .

Continence defined as not wearing a pad, was obtained in the majority of the patients. Although continent, half of the patients with a S-pouch had to empty their reservoirs with a catheter ${ }^{111,23}$. By shortening the muscular cuff of the rectum when pertorming the ileoanal anastomosis catheter emptying can be reduced ${ }^{15 \%}$. Patients with a J-pouch evacuated their reservoirs spontaneously.

Stool frequency varied from 4-7 stools per 24 hours.

A significant incidence of various postoperative complications has been reported in recent literature $(40 \%-72 \%)^{150}$ "The major problem is pelvic inflammation. Other complications due to the illeoanal anastomosis are separation of the anastomosis, probably due to tension, bleeding, fistula and delayed healing with strictures. Non-specific reservoir ileitis or pouchitis and postoperative small intestinal occlusion occurred in approximately the same percentage as in the continent ileostomy patients.

A less known complication is the regeneration of the rectal mucosa after stripping the rectal mucosa and illeoanal anastomosis. 


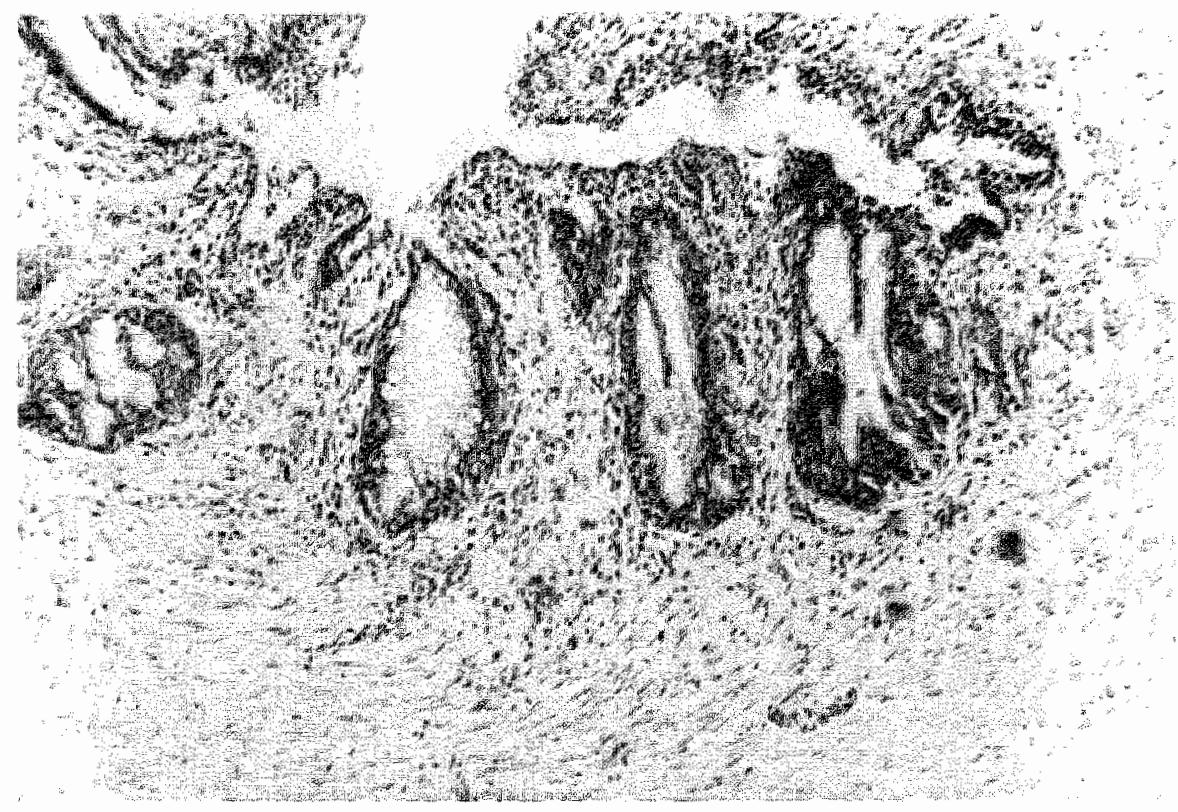

Figure 3.6 .

Rectal mucosa regeneration after mucosal proctectomy.

Regenerative hyperplasia: pseudostratification of the glandular crypt epithelium, which shows hyperchromatic enlarged nuclei surrounded by basophylic cytoplasm (high power).

Wolfstein et al. ${ }^{158}$ found it in 2 patients who previously had polyposis coli. Fasth et al. ${ }^{\text {th }}$ found in approximately half of their patients remnants or rests of rectal mucosa after mucosal proctectomy. In this study rectal mucosa was also found in 2 patients after mucosal proctectomy for polyposis coli. (see figure 3.6.). This mucosal remnant may be due to inadequate excision or due to re-epithelialisation by upward growth from the anal verge. Although no carcinoma has yet been demonstrated in ileoanal anastomosis patients, regeneration of the rectal mucosa carries the same potential risk of cancer as the original disease.

Although continence is achieved in the majority of patients, the quality of continence is yet debatable. Still a variety of complications has to be taken into account. Cancer risk in regenerated rectal mucosa can not yet be estimated.

Mucosal proctectomy and ileoanal anastomosis with a reservoir is a promising procedure in experienced hands, but awaits further evaluation. 


\section{CHAPTER 4}

\section{CONTINENT ILEOSTOMY}

\subsection{Theoretic consideration}

A coordinate muscle contraction called "peristalsis" causes the bowel content to move forward. The usual stimulus for peristalsis is distension ${ }^{61}$. If a quantity of food is collected at some point in the gut, distension stimulates the gut wall. Above a certain point, a contractile ring appears that initiates peristaltic movement. Intraluminal pressure increases and consequently, transport of the bowel contents is established. If transport is prevented the contractions of the intestinal smooth muscle will increase. Intraluminal pressure raises in order to overcome resistance. If this is not achieved, all features of mechanical ileus will develop.

The aim of a continent ileostomy is to prevent expulsion of the bowel contents. A reservoir must be formed that should not show intraluminal pressure waves on filling. A closing mechanism must be provided to prevent leakage through the outlet of the reservoir caused by raise of intra-abdominal pressure in relation to abdominal straining, coughing, laughing, etc.

\subsection{Development of technique}

\subsubsection{The reservoir}

The reservoir should fulfil two main functions. Firstly, at rest and on filling to a certain extent no pressure waves should develop. This reduces pressure on the obstructive outlet and aims to prevent reflux of the reservoir contents into the proximal small bowel. Actually some reflux occurs in all these patients ${ }^{(1)}$. Secondly, the capacity of the reservoir should be $400-500 \mathrm{ml}$ in order to limit the frequency of emptying the reservoir to approximately 3 times a day. The amount of discharge expelled from an ileostomy is approximately $500 \mathrm{ml}(250-770 \mathrm{ml})$ per dayli plus a varying amount of gas.

Intestinal pouches have been used to collect urine in patients after total or subtotal cystectomy. Most patients with such bladder substitutes become incontinent at night, because pressure waves develop, when the reservoir is filled with urine. At a certain level of pressure, leakage occurs, when the resistance of the urethral sphincter is exceeded. Analysing the pressure recordings of the intestinal bladders, Kock constructed a new type of bladder, which was used as reservoir in a few patients with an ileostomy in $1967^{\$ 2}$.

It was based on the principle that the direction of the peristaltic movement in the intestine is fixed. Even if a segment of the intestine is reversed, the direction of the peristaltic contraction waves in this segment is not changed. 

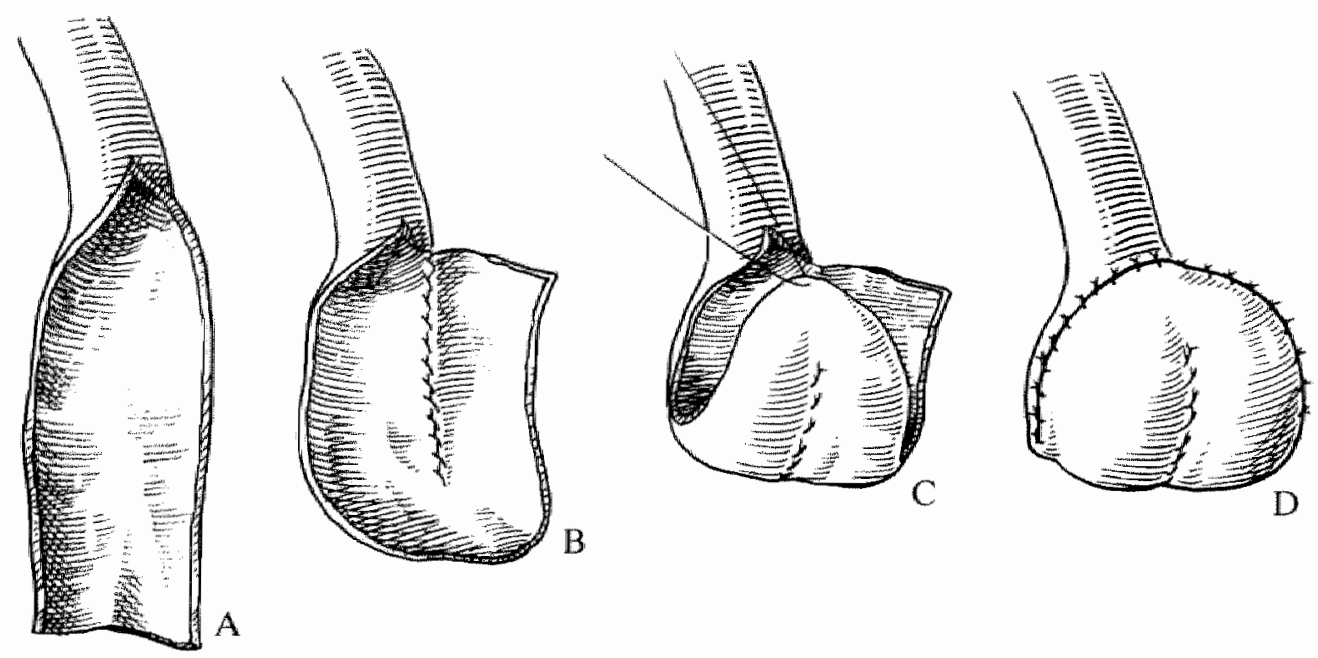

Figure 4.1.

The original procedure for construction of an ileostomy reservoir.

By splitting the intestine at its antimesenteric border (figure 4.1.A) and folding the split intestine twice, the mottor activity in the different parts of ileal segment counteracts itself (figure 4.1.B and C). Minimal rise in intraluminal pressure occurs at filling, despite vigorous motor activity ${ }^{39}$. Postoperatively the reserwoir capacity is $50-100 \mathrm{ml}$ and will increase during the first 6 months to approximately $700 \mathrm{ml}$ at a maximum, whereafter it remains stable, 84 .

Though reduced in comparison with a normal terminal ileum, Cranley and McKelvey ${ }^{30}$ found in dog experiments that the Kock reservoir possesses significant motor activities under basal conditions and on filling. These findings were confirmed by patients studied by Kock"s group ${ }^{\text {ty }}$. At the first stage after operation some motor activity was recorded during infusion of saline. These pressure waves started to appear when the reservoir had been distended to approximately $40 \%$ of the maximum volume capacity and increased in frequency, duration and amplitude with increasing filling of the reservoir. During the first year the total motor activity decreased indicating an adaptation of the intestinal smooth muscle to distension.

The ileal pouch is a low pressure reservoir.

\subsubsection{The outlet}

Kock created no special outlet in the original procedure ${ }^{\text {k2 }}$. After proctocolectomy the reservoir was constructed. The opening at the corner of the reservoir was pulled through the abdominal wall. After eversion the intestinal wall was sutured to the edges of the opening in the skin. Although five patients who were provided with this type of ileostomy could manage for long times without carrying external appliances, they occasionally experienced leakage of gas and ileum effuence. To prevent leakage the outlet had to be improved. Three types of outlets have been tried out ${ }^{83,84,86}$. 


\section{Figure 4.2.}
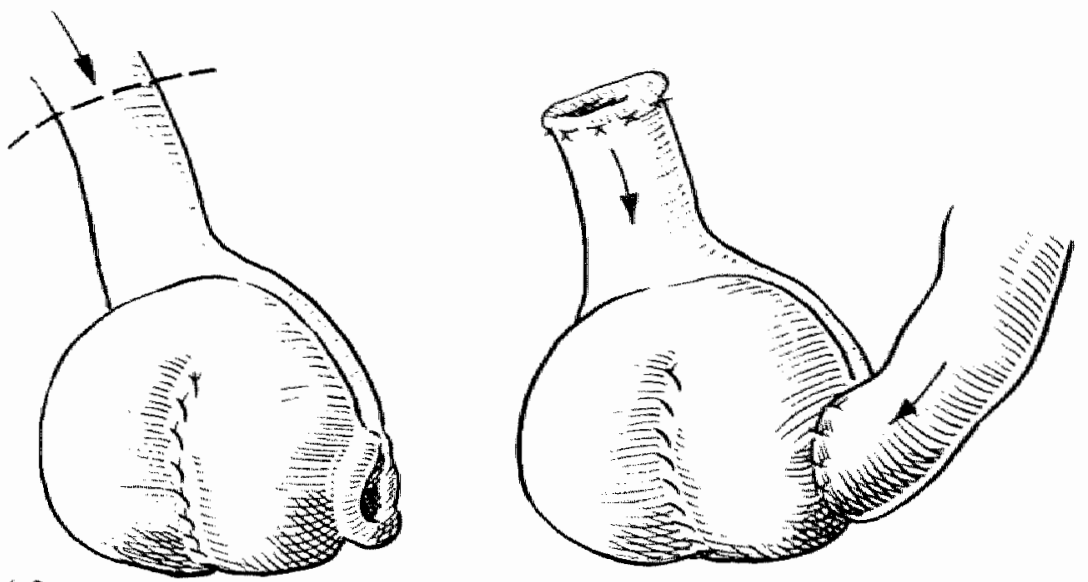

Construction of anti-peristaltic outlet.

\subsubsection{Antiperistaltic outlet}

After the reservoir was constructed, a small opening was left in one corner. The afferent ileum was then divided $8-10 \mathrm{~cm}$ proximal to the reservoir and the proximal end of the divided intestine was anastomosed to the open corner. The distal part of the divided ileum formed the antiperistaltic outlet of the reservoir and was used as ileostomy (figure 4.2.).
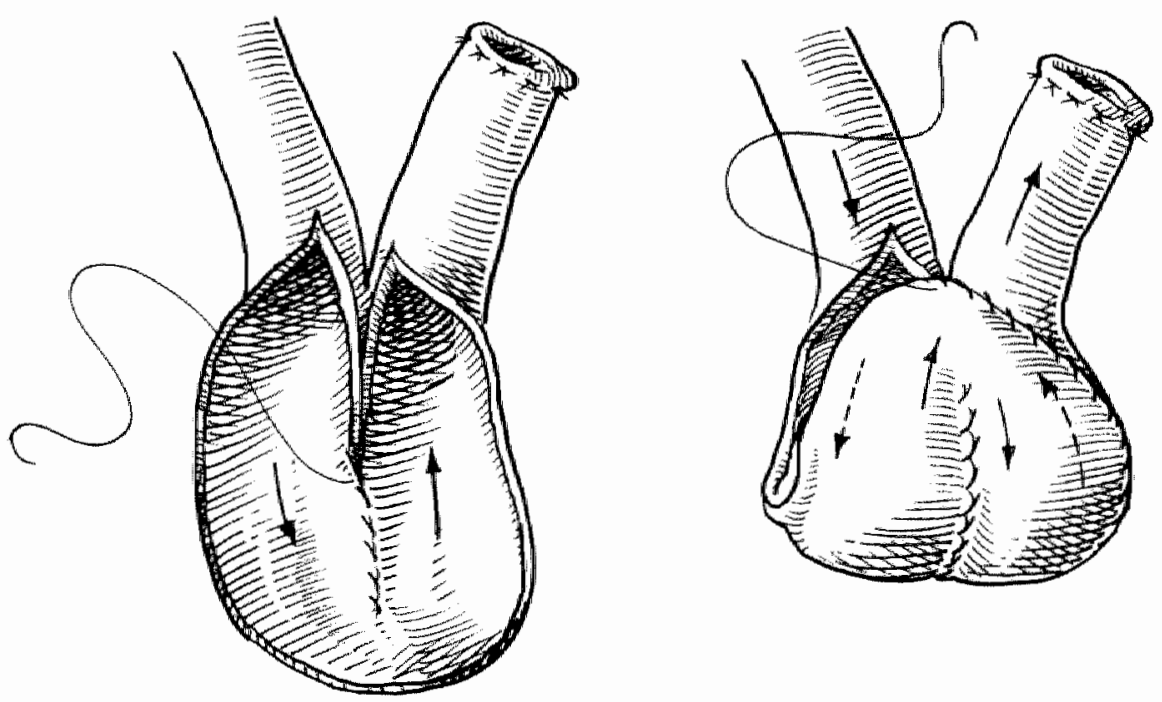

Figure 4.3.

Construction of ileostomy reservoir and iso-peristaltic outlet. 


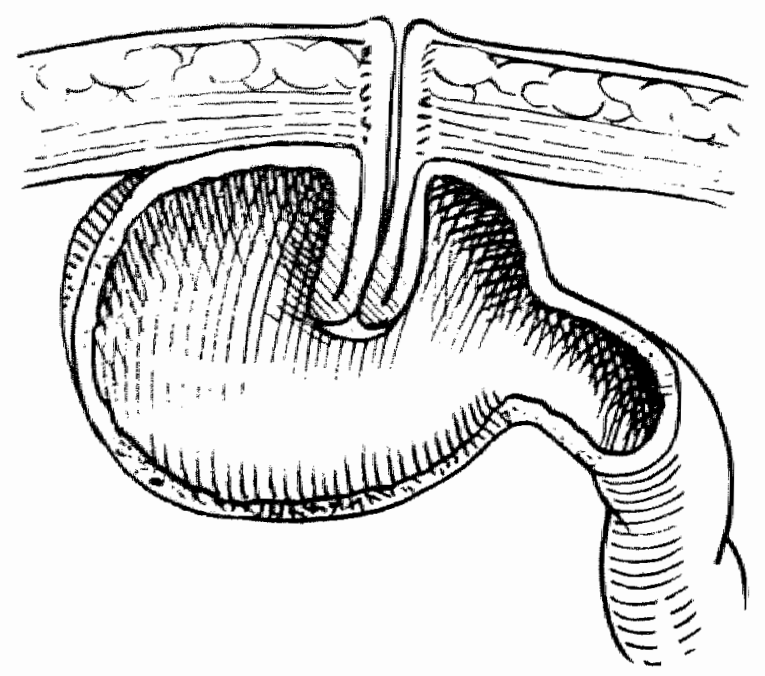

Figure 4.4.

The nipple valve is constructed by intussuscepting a part of the outlet into the reservoir. The stoma is made flush with the skin and the distance from stoma to pouch is minimal-short.

\subsubsection{Isoperistaltic outlet}

A length of distal ileum needed for passage through the abdominal wall was left. Then a reservoir was made and the distal ileum was connected to the skin, while it emerged between two crossed bundles of rectus muscle, working like a valve (figure 4.3.).

\subsubsection{Outlet with a "nipple"}

Approximately $15 \mathrm{~cm}$ of the distal ileum was left untouched. A reservoir was created from an ileal segment of $30 \mathrm{~cm}$ proximal to this segment. Before folding the small bowel a second time to accomplish the reservoir, the terminal unsplit ileal segment was partly intussuscepted into the lumen of the reservoir (figure 4.4.). The intussuscepted "nipple" projecting into the reservoir measured $4-5 \mathrm{~cm}$. Then the reservoir was closed. The nipple valve proved to be the best method. In $1973 \mathrm{Kock}^{\mathrm{si}}$ reported that only 3 out of 37 patients with the nipple valve had occasional leakage of gas. All 21 patients with an isoperistaltic outlet suffered to some extent from gas leakage. Only in 7 out of 26 patients with the antiperistaltic outlet gas leakage never occurred.

Initially some difficulties in inserting the tube through the nipple valve were reported. 

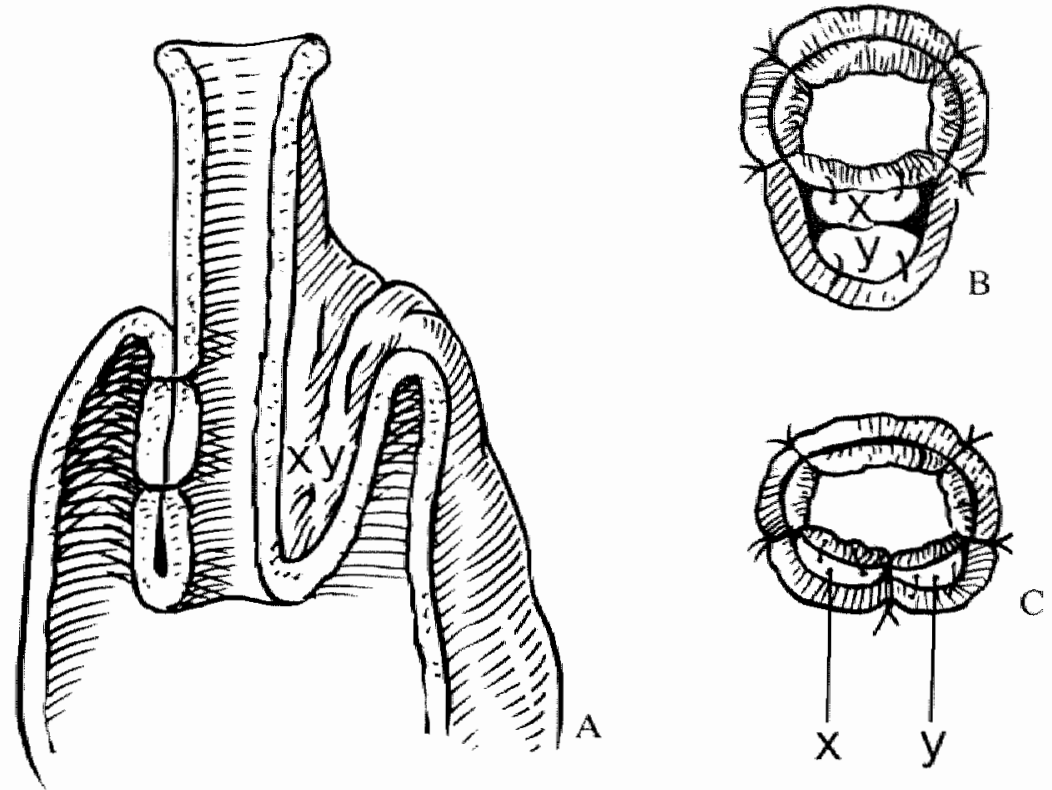

Figure 4.5.

A.B. By intussuscepting the small bowe $\downarrow$ a bulk of mesentery is formed between the two intestinal layers.

C. Rotation of the intussuscepted intestine divides the mesenteric mass into two parts.

Apart from tightness of the nipple or the uncertainty of inserting the catheter, it could be due to shifting of the position of the pouch in relation to the stoma ${ }^{156}$. The latter can be eliminated by attaching the pouch to the parietal peritoneum directly beneath the side of the stoma. The stoma is made flush with the skin. By accomplishing this, the distance from stoma to pouch is minimal-short, the pouch is fixed and the direction for inserting the tube is known?

If the nipple valve is constructed in the proper way, without complications, complete continence can be expected. However, the valve has a natural tendency to dessuscept. Because of peristaltic activity, it is prone to reduce itself. At the mesenteric side, the mesentery forms a bulk between the two intestinal layers and prevents firm fixation of the intussusception (figure 4.5.A,B). 

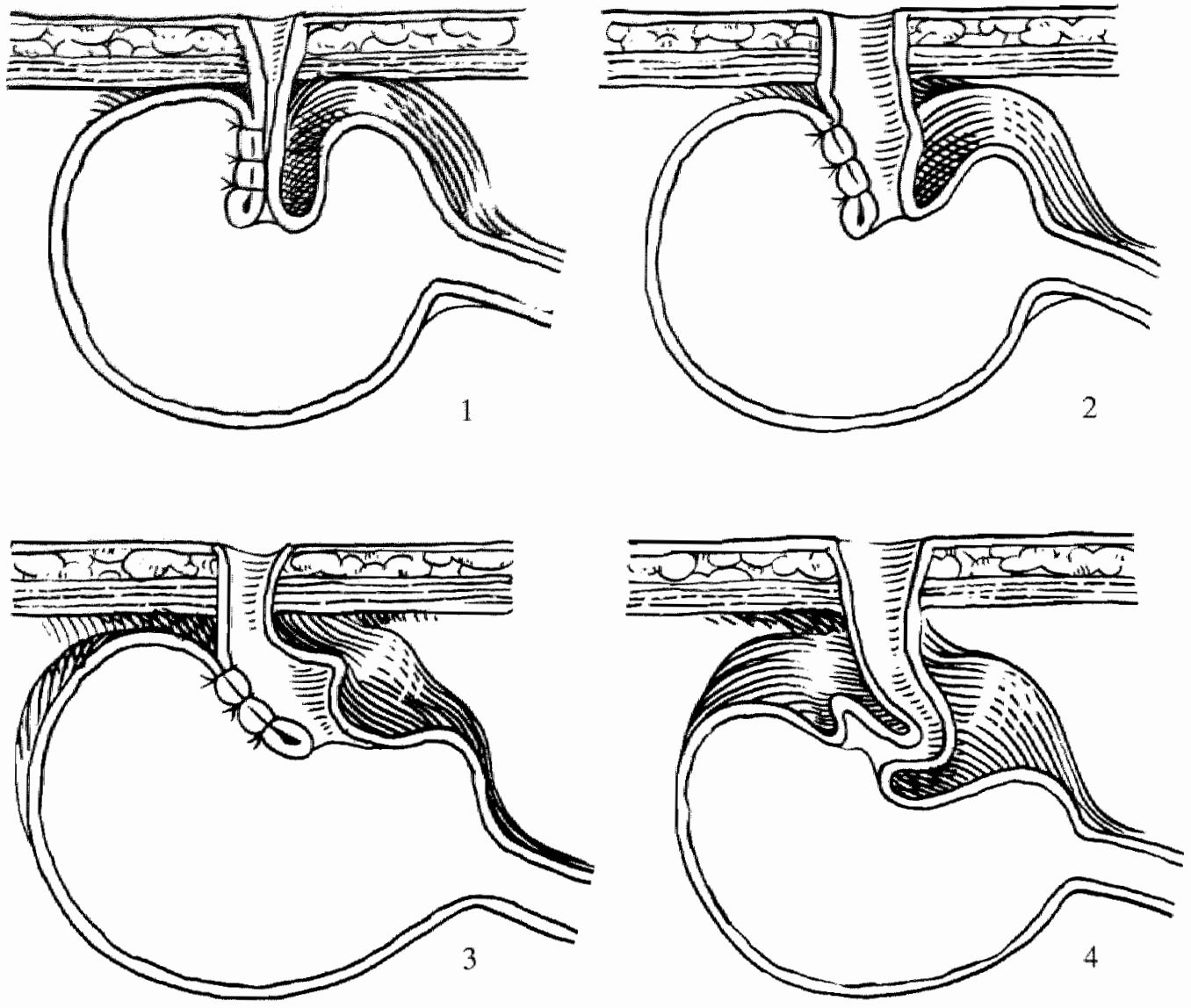

Figure 4.6.

The mechanism of valve dessusception.

When the reservoir dilates intramural tensions develop at the site of the sutures at the base of the nipple valve and tend to tear the two intestinal walls apart. At the same time the intussuscepted intestine is stretched by dilation of the reservoir trying to dessuscept the intussusception on the mesenteric side. The nipple valve is dislocated to the mesenteric side (figure 4.6.). Insertion of the catheter becomes difficult. The nipple valve becomes shorter, first on the mesenteric side, later on the antimesenteric side too. The final state will be incontinence ${ }^{88}$.

This mechanism of dessusception is described in detail because the nipple is the Achilles' heel of the operation. Many techniques were considered to prevent slippage of the nipple valve. 

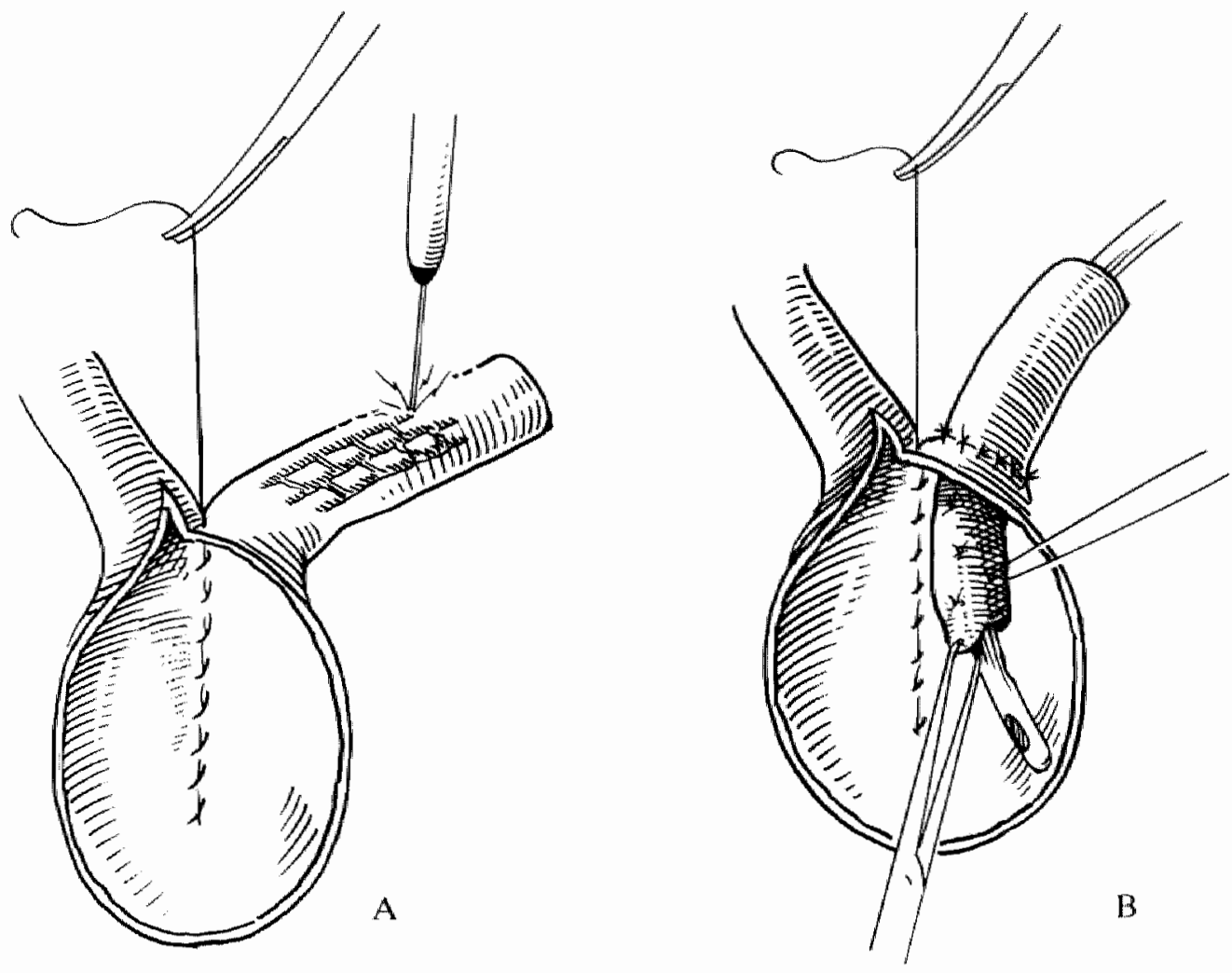

Figure 4.7.

A. Coagulation with diathermy of the serosa causes scarification, which promotes adhesion formation between the serosal layers.

B. The intussuscepted intestine is fixed by placing non-absorbent sutures through both intestinal walls.

Coagulation with diathermy of the serosa of the intussuscepted intestine causes scarification, which promotes adhesion formation between the serosal layers. The intussuscepted intestine is fixed by placing non-absorbent sutures through both intestinal walls ${ }^{84}$ (figure 4.7.). External sutures at the base of the intussusception to the reservoir are placed completely around the efferent intestinal segment without jeopardizing the blood supply, may be very valuable ${ }^{8}$.

To reduce the mesenteric mass Kock proposed the following technique ${ }^{45}$. An opening is made in the middle of the mesentery of the segment which will be intussuscepted. Sutures are placed on both sides of the mesentery, resulting in rotation of the intussuscepted intestine. In this way the mesenteric mass is divided into two parts (figure 4.5.C). At the same time the peritoneum of the mesentery supplying the segment for the nipple valve construction is removed, together with a part of the mesenteric fat, on both sides, leaving the blood vessels intact ${ }^{86,10 \%}$. 


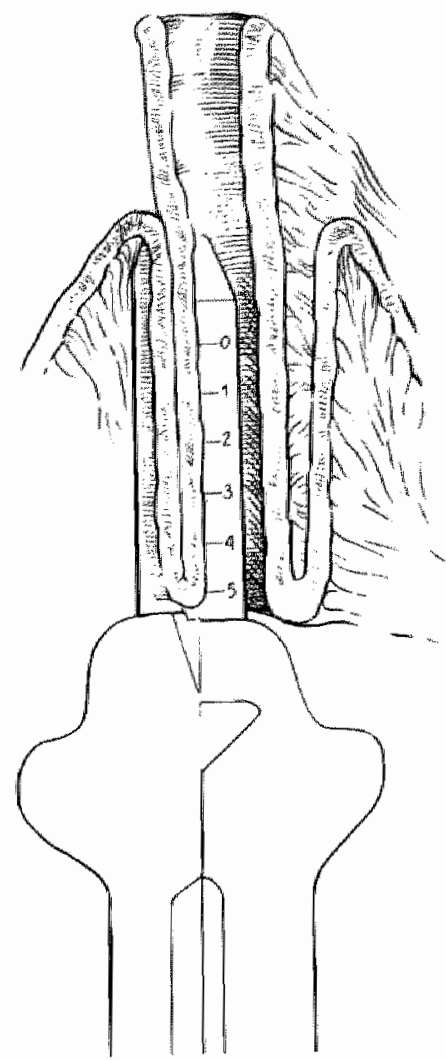

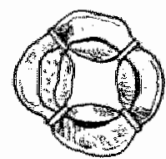

Figure 4.8 .

Construction of the nipple valve with GIA-staples.

Instead of insertion of through-and-through non-absorbent sutures in the nipple to prevent dessusception the use of GIA staples was worked out ${ }^{143}$. After intussusception of the intestine, on the mesenteric side, two rows of staples were placed on either side of the vascular component. In addition, one or two rows of staples were placed on the antimesenteric side. This is a quick but a rather expensive method (figure 4.8.).

Since most of the problems appear to be at the mesenteric side of the intussusception, specific attention was given to this side. Bokey and Fazio ${ }^{13}$ used a strip of posterior rectus lascia to fix effectively the mesenteric side of the intussusception. Two windows were made in the mesentery $2 \mathrm{~cm}$ proximal to the planned beginning of the valve and one window opposite the planned end of the valve. The strip of fascia was threaded through these windows. The valve was intussuscepted and the fascia sling encircled the base of the nipple. Without making the passage through the outlet too tight, sutures were placed to hold the fascia in place (figure 4.9.).

Beside fascia, a Marlex ${ }^{\oplus}$ mesh (a knitted polypropylene) was also used ${ }^{88}$. Light microscopy revealed that scar tissue grew into and around the mesh filling the space between both serosa segments. The mild foreign body reaction encouraged the formation of connective tissue between the segments. The base of the valve including the mesenteric side, was firmly adhered to the rectus sheath ${ }^{13}$. Although sliding of the nipple valve has almost been eliminated, Cohen ${ }^{26}$ noticed that the number of peristomal infections and enterocutaneous fistulas increased. In his opinion this was probably due to the introduction of the Marlex $x^{(8)}$ mesh. For the same reason Kock also abandoned the use of a Marlex ${ }^{\text {(3) }}$ mesh $^{93}$. 

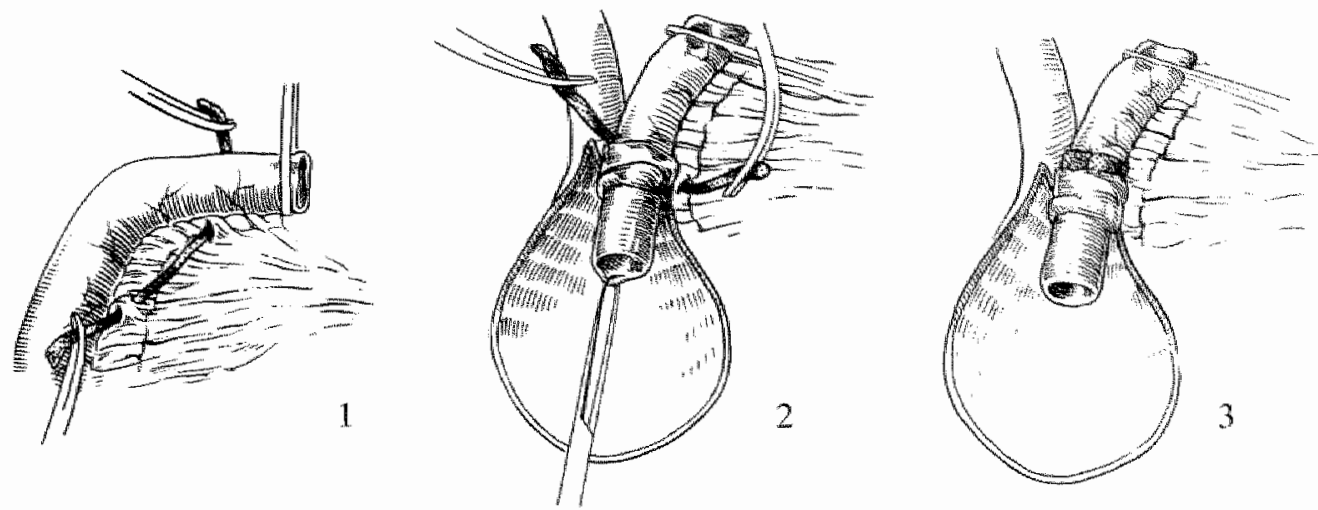

Figure 4.9 .

A strip of posterior rectus fascia or Marlex mesh encircles the base of the nipple and fixes the intussusception of the small bowel.

To investigate the competence and stability of the nipple valve constructed by dilferent techniques, Cranley and McKelvey ${ }^{28}$ found that the most stable valve was provided by a method which removed the entire mesentery to the segment of ileum used to construct the valve. This piece of bowel, completely deprived from its mesentery, was much easier to suture. Their main fear is that the blood flow will be impaired and necrosis will occur. Although necrosis does not occur in experimental animals the use of this technique is not reported in human beings.

Meijer et al. ${ }^{104}$ tested the use of dermal sheep collagen instead of staples to fix the invagination of the small bowel on 10 mongrel dogs. A firm adhesion was found between the two serosal layers.

In 1981 Hulten and Fasth ${ }^{68}$ introduced the idea of giving a proximal loop ileostomy to defunction the reservoir. The valve was made by intussusception of the ileum segment, after careful stripping its mesenteric peritoneum and fat on both sides "The intussusception was fixed in position by interrupted sutures around the circumference of the outlet. The reservoir was kept in an undistended state, which released tension on the suture lines and lessened the risk of leakages. At the same time the nipple valve was allowed to become firmly fixed in position before any strain was brought to bear on it. After 2 to 3 months the loop ileostomy was closed. Although 2 operations were required the results were encouraging. The loop ileostomy should be placed as distal as possible to prevent metabolical complications, if a too large part of small bowel is defunctioned. All patients made favorable recoveries in the immediate postoperative period and very low incidence of ileostomy extrusion occurred, in spite of the fact that a very simple technique of valve construction was used.

Experimental work on the outlet stil continues. Starrenburg ${ }^{142}$ investigated the possibility of producing an ileostomy sphincter by electrical stimulation of the intrinsic intestinal musculature and to bring them into a condition of permanent contraction by means of electrodes implanted in the intestinal wall. Other alternative ileostomy valves have already been discussed in chapter 3.2. All these efforts showed that making a reliable and continent outlet still remains the most difficult part of the operation and deserves the surgeon's utmost attention. 


\subsection{Biologic consequences}

A continent nipple valve will prevent outflow of small bowel effuent. There will be permanent stagnation of intestinal content. Theoretically it can be compared to a "blind loop" "s, 134 . The stasis of ileum content might stimulate bacterial growth, produce mucosal irritation and interfere with normal absorption.

Therefore, studies were made of the bacterial flora of the ileostomy reservoir ${ }^{16,76,97}$, of the morphology of its mucosa ${ }^{114,127}$ and of the absorption of water, salts, sugar, amino acids, fat, bile salts and Vitamin $B_{12} 2.47,73,74,112.115,135$ in patients with a reservoir.

\subsubsection{Bacteriology}

The microbial flora of ileostomy effluent showed a characteristic flora different from both microbial population of normal faeces and microbial flora in the terminal ileum in healthy individuals ${ }^{50}$. The ileum reservoir will be supplied with microorganisms from the intestinal canal as well with microorganisms brought in through the nipple when a catheter is introduced. The temperature in the reservoir and the rich supply of nourishment promotes bacterial growth. Brandberg ${ }^{16}$ found that the ecology of the reservoir seemed to hold an intermediate position between ileostomy effluent and normal faeces. This situation is relatively stable, but sometimes overgrowth was found which induces a mucosal enteritis, resulting in clinical symptoms such as excessive fluid loss. Response to metronidazole with its anaerobic spectrum of activity suggests that anaerobe micro-organism or their by-products might be responsible for the clinical effects $^{75}$.

\subsubsection{Morphology}

Nilsson et al. ${ }^{114}$ found that the creation of an ileostomy reservoir leads to a decrease in villus height, but to an increase in the number of crypt cells and mucosal volume. During the first year after operation the epithelial turnover increased but after 6 to 10 years turnover seemed to normalize. These morphological changes represent a hyperregenerative response to chronic irritation. The constant presence of noxious contents, probably rich in bacterial toxins and metabolites, seems most likely to be responsible for the non-specific morphological changes recorded in the reservoir ${ }^{86}$. Histochemical investigations showed that the reservoir mucosa revealed largely unchanged strong enzymatic activity involved in both oxidative metabolism and secretory functions as well as the production of PAS-positive material in the epithelial cells ${ }^{1 ! 4}$.

There were no signs of alarming changes such as dysplasia, fibrosis or progressive atrophy. After 15 years of follow up, no patients were found to have cancer of the pouch ${ }^{36}$.

\subsubsection{Absorption}

A changed bacterial flora and an altered mucosa morphology might interfere with the normal absorption. This has been subject of extensive investigation. Absorption stu- 
dies performed in patients with conventional ileostomies and in patients with ileostomy reservoirs revealed no significant differences in the absorption of D-xylose, L-phenylalanine or fat, although some subnormal values were found in both groups of patients ${ }^{7.126}$. The main site where absorption of sugars and amino acids takes place is in the proximal intestine.

No signs of sodium or potassium depletion were found in the continent ileostomy patients ${ }^{116}$. Sodium, chloride and water were absorbed by the pouch in a manner similar to that reported for the normal ileum ${ }^{4}$. Nevertheless, Stern et all ${ }^{14 t}$ found a reduced urinary volume and $\mathrm{Na} / \mathrm{K}$-ratio both in conventional and continent ileostomies as compared with a control group. In the Kock ileostomy group no significant reduction of uric acid concentration in urine was found. These results suggest that there is no significant risk for urine acid stone formation in Kock ileostomy patients.

More interesting is the absorption of Vitamin $B_{12}$ and bile acids that takes place in the terminal ileum. In various studies ${ }^{47.72 .112 .115 .135}$ the reabsorption of Vitamin $B_{12}$ was measured by the Schilling test. In approximately $10 \%$ the absorption was reduced. If, however, Vitamin $B_{12}$ was instilled in the pouch together with intrinsic factor Gadacz et all ${ }^{47}$ found a normal absorption.

In a large study Nilsson et al. 115 found in $14 \%$ subnormal or "border line" values of plasma Vitamin $\mathbf{B}_{12}$ measured by a microbiological method. This was particularly found in patients with Crohn's disease. However, neither anemia nor neurological symptoms were found after an average follow-up time of 7.5 years. They saw no reason for prophylactic substitution of Vitamin $B_{12}$, nevertheless, regular follow-up was advised.

At the time of mucosal enteritis malabsorption of Vitamin $B_{12}$ may occur. Oral antimicrobial therapy decreases the concentration of Bacteroides species in ileum and in this way increases the reabsorption of Vitamin $B_{12}{ }^{135}$.

Several studies ${ }^{2,75,97: 112}$ found an increased loss of cholic acids. No conclusions could be drawn as to whether the impaired absorption was caused by bacterial deconjugation of cholic acids or by impaired absorptive capacity of the intestinal mucosa. However, the bile acid malabsorption seemed to be of minor importance since only occasionally steatorrhoea was demonstrated.

In conclusion, studies of bacteriology, morphology and absorption demonstrate that the ileal mucosa of the intestinal segment, used for construction of a continent ileostomy reservoir, undergoes an alteration. This is probably caused by its continuous contact with a noxious medium and/or bacterial flora changes. However, the epithelial covering remains intact and maintains its absorptive capacities.

\subsection{Indications and contra-indications}

The continent ileostomy seen as an terminal ileal outlet is constructed after total removal of the large intestine.

Inflammatory bowel disease, multiple malignant or premalignant tumors affecting the entire large intestine and some congenital disorders necessitate this.

As more data about the continent ileostomy patients become available, a better selection for possible candidates can be made. It seems that a continent ileostomy must not be recommended in the following cases: 
1. Elderly patients.

Elderly patients are more prone to potential lethal postoperative complications including multiple revision operations ${ }^{126}$. Furthermore, the older the patients, the greater was the probability of revision. After one year, valve revision was necessary in $12 \%$ of the patients in the second decade of their lives and in $35 \%$ of the patients in the fifth decade of their lives ${ }^{34}$.

2. Patients with Crohn's disease.

Crohn's disease tends to occur in the distal ileum. A high risk of reservoir excision due to recurrence of disease leads to loss of an excessive amount of small intestine. Kock ${ }^{k 7}$ found a recurrence of Crohn's disease in 17 patients out of 49 patients with a continent ileostomy. In 8 patients the reservoir had to be removed.

Only strongly motivated patients without signs of active diseases and not steroid dependent for 5 years or more may be taken into consideration to have a continent ileostomy"l.

3. Obese patients.

Schrock ${ }^{137}$ found that in three-quarters of obese patients reoperation was required for reduction of the nipple valve.

4. Patients who previously underwent small bowel resection.

Approximately $45 \mathrm{~cm}$ terminal ileum is needed for the operation. If the pouch for some reason has to be excised, this can become a metabolic disaster.

5. Critically ill patients.

During emergency surgery a staged procedure is to be preferred.

6. Young patients, patients with a low intelligence and unstable, psychiatric patients.

Patients with a continent ileostomy must be able to understand that the reservoir must be regular $\| y$ emptied. Ein ${ }^{38}$ advises not to select children younger than teenagers for this procedure. Golden ${ }^{54}$ suggests to carefully evaluate every patient with a psychiatric history. Patients who use any illness self-destructively or for secondary gain present particular risks in surgical procedure. A life threatening situation might appear, if the reservoir is not regularly emptied in the post operative period. Moreover, a continent ileostomy cannot solve lifelong problems or restore broken relationships.

Although the concept of a continent ileostomy is very attractive, some disadvantages should be mentioned. It is a difficult operation to perform. The construction of a continent ileostomy is a major intestinal operation and several details of the procedure must be meticulously followed in order to achieve satisfactory functioning of the ileostomy. The surgeon must know the complications and moreover, know how to deal with them. This operation should only be done in some centres which have experience with this type of ileostomy.

Finally, the patients must be aware that continence cannot be assured and complications may occur. Patients must decide for themselves whether the motive for the operation is based on a major concern for social and sexual aspects or problems with an ill-fitting appliance and skin problems. 
Table 4.1.

Review of the diagnoses and results of the continent ileostony operation in the literature.

\begin{tabular}{|c|c|c|c|c|c|c|c|c|c|}
\hline Year & Author & $\begin{array}{c}\text { Number } \\
\text { of } \\
\text { patients }\end{array}$ & $\begin{array}{l}\text { Ulcerative } \\
\text { colitis }\end{array}$ & $\begin{array}{l}\text { Diagnosis: } \\
\text { M.Crohn }\end{array}$ & $\begin{array}{c}\text { Pollposis } \\
\text { coli }\end{array}$ & Other & Deaths & $\begin{array}{c}\text { Continent } \\
\text { ileostomies } \\
\text { removed }\end{array}$ & $\begin{array}{c}\text { Percentage } \\
\text { of continent } \\
\text { prtients }\end{array}$ \\
\hline 1975 & King & 10 & 9 & 1 & . & . & 0 & -. & $60 \%$ \\
\hline 1976 & Golighers? & 26 & 23 & 3 & - & - & 0 & 6 & $69 \%$ \\
\hline 1978 & Halvorsen ${ }^{62}$ & 36 & 34 & 1 & 1 & - & 4 & 6 & $94 \%$ \\
\hline 1978 & Loygue & 17 & 10 & 1 & 6 & - & - & 3 & $76 \%$ \\
\hline 1978 & Palmu ${ }^{121}$ & 51 & 48 & 1 & 2 & - & $\mathbb{1}$ & 1 & $88 \%$ \\
\hline 1979 & Schrock & 39 & 32 & 4 & - & 3 & 0 & 3 & $87 \%$ \\
\hline 1981 & Valkamo ${ }^{154}$ & 51 & - & - & - & - & 6 & - & $82 \%$ \\
\hline 11982 & Cohen ${ }^{26}$ & 85 & 17 & - & - & - & 0 & 0 & $96 \%$ \\
\hline 1982 & $\operatorname{Ein}^{38}$ & 16 & 14 & - & I & 1 & 0 & 0 & $100 \%$ \\
\hline 1982 & Sauberii ${ }^{134}$ & 45 & 38 & 5 & - & 2 & 1 & 1 & $95^{\circ} \%$ \\
\hline 1983 & Barnett & 19 & 15 & 1 & 3 & - & - & $!$ & $95 \%$ \\
\hline 1983 & Gelernt & 300 & - & - & " & - & - & 2 & $90 \%$ \\
\hline 1983 & Gerber ${ }^{50}$ & 100 & 78 & 16 & 3 & 3 & 1 & 3 & $99 \%$ \\
\hline 1984 & Dozois & 443 & 403 & 11 & 29 & - & 0 & 5 & $95 \%$ \\
\hline 1984 & Failes $^{4.3}$ & 49 & 44 & - & 4 & 1 & 0 & 4 & $94 \%$ \\
\hline 1984 & Mc Leod 103 & 71 & 66 & 2 & 2 & 1 & 0 & . & $86 \%$ \\
\hline 1985 & Kock $^{9 !}$ & 435 & 335 & 64 & 22 & 1.4 & 7 & 16 & $97 \%$ \\
\hline
\end{tabular}

\subsection{Technique of operation}

A terminal segment of $45 \mathrm{~cm}$ of the small bowel is used to construct a reservoir and an outlet. The reservoir is made by double folding the proximal part of this segment. A valve is formed by intussuscepting the distal part of the segment.

As this procedure was subject to modifications and improvements many techniques were described in the literature. In chapter 6.3. the operation technique as used in the "De Wever" Hospital will be described in detail.

\subsection{Results}

The continent stoma gradually obtains a place in surgery as the increasing number of reports shows. Table 4.1. gives a review of the diagnoses of the operated patients and the results. Most patients were operated in the fourth decades of their lives. The sex ratio is equal for both male and female. The continent ileostomy procedure was performed at the same time as the colectomy in $47 \%$. In $53 \%$ a conventional ileostomy was converted to a continent lleostomy.

In 1978 Goldman ${ }^{55}$ reviewed the results of 479 patients who were operated on a continent ileostomy. In $78 \%$ continence was achieved. Until now over 2,000 patients have been operated in order to obtain a continent ileostomy. In table 4.1. 1,793 patients are reviewed. Continence was achieved in approximately $95 \%$ of the patients. The term "continence" might be confusing because in one study it means no gas or fluid leakage at all ${ }^{33}$, whereas in another it means no use of ileostomy appliances ${ }^{84}$. Most of the time continence is not defined. 
In this review the overall mortality of performing a continent ileostomy is $1 \%$. Threequarters are directly related to the procedures. Anastomosis leakage, which results in peritonitis is the major cause of death. This is understandaole as a long suture-line is needed to construct the reservoir. The same reason makes that in the beginning some surgeons $\mathrm{s}^{5,83}$ advise not to construct a continent ileostomy in patients taking large amounts of steroids. Obviously, this could not be supported by data ${ }^{137}$. In $3 \%$ the continent ileostomy had to be removed. This was mainly due to recurrence of M. Crohn in the reservoir. Some severe cases of non-specific enteritis led to removal, particularly at the time one was not familiar with this complication. Other reasons were anastomosis leakage, recurrent valve prolapse and in three cases removal took place on patients' request, because of dissatisfaction with the continent ileostomy.

\subsection{Complications}

A major disadvantage of this procedure is the high re-operation rate to achieve a good result. It varies from 30 to more than 40 per cent ${ }^{\prime}$. The main reason for reoperation are valve problems. Other reasons for reoperation were intestinal obstruction due to adhesions, intra-abdominal abscesses and fistulae from the reservoir. When gradually more experience is gained and better methods of nipple valve construction are used, the number of reoperations will be reduced to a half $f^{33,34,89}$ or even less ${ }^{41}$.

The major complication is dysfunction of the nipple valve, which occur in up to $40 \%$ of the patients. Causes of dysfunction include valve necrosis, sliding of the nipple valve, which means dessusception of the terminal bowel segment, prolapse or eversion of the nipple valve and stenosis of the outlet at skin level.

Necrosis of the valve is seen during or shortly after the operation. The valve should be excised immediately and a new valve should be constructed.

Sliding of the nipple valve leads to difficulties in inserting the catheter and, later on, leakage of gas and ileum effluent. The diagnosis becomes obvious from case history, but can be confirmed by examination of the nipple valve by a children's proctoscope. Radiological investigations are also valuable, especially the double-contrast technique $^{\text {i.t. }}$. Operative correction is needed. Simple restoration of the intussusception can be done. If this is not possible a new nipple valve can be constructed from the afferent loop of the reservoir after dividing the afferent segment at a suitable level. The reservoir is rotated and the former inlet is used as outlet. The proximal part of the divided intestine is anastomosed to the former outlet in the reservoir. Another possibility is using an isolated part of the proximal ileum to construct a nipple valve. This valve replaces the former construction after transposition.

Prolapse of the nipple valve might be caused by an opening which is too wide, through the abdominal wall. Surgical correction can be attempted by narrowing the fascia and the rectus muscle around the outlet. Sometimes resiting the ileostomy is necessary. Stenosis at skin level can be corrected in the usual way by excising a skin edge circumferentially and resuturing the intestine to the skin.

Fistulas occur in 8 to 10 per cent of patients following continent ileostomy operation, being the second but one most frequent complication that needs reoperation ${ }^{146}$. Early fistula formation may occur from an anastomosis leak of the ileal reservoir. These fistulas appear in the laparotomy wound. They are generally managed successfully by catheter drainage of the reservoir. 
Fistulas most frequently occur in the nipple walve. Rotational sutures, through and through, sutures in the valve, excessive diathermy of the serosa, and the Marlex mesh are responsible. Recurrence of Crohn's disease may present itself with a fistula. Incontinence is the patients" main complaint. The diagnosis is usually made by clinical suspicion and endoscopical examination of the nipple and reservoir might be beneficial. Radiographic demonstration of the fistula and its location can be tried, although this investigation only occasionally reveals a fistulous track ${ }^{41}$. The management is usually operative. Excision and closing of the fistula can be tried, but often a new nipple valve should be constructed. Fistulas caused by prosthetic materials require removal of the prostheses. Then closure of the fistula can be obtained. In Crohn's disease operative therapy is almost always inevitable and sometimes leads to removal of the continent ileostomy.

In 13-45\% mucosal enteritis, of the reservoir, rather called pouchitis, a non-specific inflammation of both mucosa and submucosa is reported ${ }^{14}$. It usually begins with abdominal pain and diarnoea. The patients observe that the intestinal discharge becomes liquid, and the amount of discharge increases. Bleeding may also be observed to some extend. Incontinence may develop. When the inflammation is severe, the patient loses electrolytes and may become dehydrated. When examining the reservoir by children's rectoscope, the mucous membrane appears inflamed with hemorrhage while small ulcers in the mucosa may be seen.

Radiological investigations show inflammatory changes.

Disappearance of normal mucosal pattern and thickening of the mucosal folds, which become irregular and blunted and sometimes a cobblestone appearance, can be seen ${ }^{117}$. Kock $^{86}$ noticed that these inflammatory changes developed in reservoirs of patients operated for Crohn's disease (38\%) and ulcerative colitis (13\%). He did not find ileitis in patients operated for familial polyposis. It is thought that an overgrowth of anaerobic bacteria, including their metabolites, coupled with stasis in the reservoir account for the inflammation. High success rates of treatment are reported with the use of metronidazole. In more severe cases metronidazole treatment is to be combined with continuous drainage of the reservoir. Some unfortunate patients need excision of the reservoir ${ }^{43}$

Fortunately, perforation due to inserting of the catheter in the reservoir seldom occurs. The more so if one realizes how often this action takes place. This complication occurs usually in the immediate postoperative period. The suture lines of the reservoir not yet fully healed, might cause this complication, perhaps in combination with the inexperience of the patient.

Finally, a group of complications not specially related to the construction of a continent ileostomy may occur. In this group obstruction due to adhesion gives rise to the majority of reoperations. This can be the result of the high reoperation rate in these patients. Proctocolectomy, which is a major procedure, contributes thereto ${ }^{\text {lik: }}$.

The number of reoperations because of wound dehiscence or intra-abdominal abscesses gradually decreases as a result of the extensive use nowadays of antimicrobial prophylaxis in gastro-intestinal surgery. 


\subsection{Quality of life}

The continent ileostomy offers the patient a quality of life which is superior to life with a conventional ileostomy as stated by Kock ${ }^{86}$. To what extent is this quality of life better and is it worth running the risk of an operation with a possible risk of complications and even mortality to achieve continence?

The word "freedom" is mostly used to describe the new style of lifes. There is no restriction for any kind of clothing as there is no need to wear a bag. Skin problems are non-existing. Those patients who previously lived for several years with a conventional ileostomy were the most grateful ones.

After conversion from a conventional to a continent ileostomy McLeod et al. ${ }^{102}$ reported that $68 \%$ of the patients noticed an improved sex life and $80 \%$ noticed an improved body image. All patients would retrospectively choose to have a continent ileostomy and $96 \%$ found the results as good as or even better than they preoperatively expected. If complications would arise, $97 \%$ of the patients would undergo revisional surgery rather than removal of the continent ileostomy.

Gerber et al..$^{51}$ reported an overall patient satisfaction of $98.7 \%$. Improvement was reported in social activities $(96.2 \%)$, athletic endeavours $(87.5 \%)$ and sexual relationships $(76.2 \%)$.

Patients spent less time taking care of the stoma $(92.5 \%)$ and wore street and beach attire with greater ease $(97.5 \%)$.

Nilsson et al. ${ }^{13^{3}}$ studied the sexual adjustment in ileostomy patients before and after conversion to continent ileostomy.

Almost all patients had sometimes felt embarrassed, uncertainty or inhibition by the conventional stoma, whereas only one-quarter had had these reactions after conversion to a continent ileostomy.

Almost $50 \%$ of the patients reported reduction or absence of their sexual activities. After conversion $95 \%$ considered their sexual activities to be normal. One-third of the ileostomy patients claimed that their partners had been embarrassed by the conventional ileostomy, but no partner had a negative reaction towards the continent ileostomy. They concluded that sexual life was improved in $85 \%$ of the cases.

These studies underline that if someone endures a proctocolectomy a continent ileostomy should be suggested, if possible. 
PART II

OWN INVESTIGATIONS 


\section{CHAPTER 5}

\section{AEPIDEMIOLOGICAL SURVEY OF ILEOSTOMY PATIENTS IN THE NETHERLANDS}

\subsection{Introduction}

The exact number of patients with a stoma in the Netherlands is not known. The Harry Bacon Club, the Dutch stoma patient association, and the stoma appliance producing industries estimate the number of patients to be 20,000. A quarter of these people are said to have an ileostomy. More specific data on ileostomy patients, such as the reasons for having an ileostomy, their age at operation etc. are not known.

Fortunately, data about hospital patients having an ileostomy are registered nationally by the SIG ("Stichting voor de Gezondheidszorg"). In almost every hospital there is a department which collects data of the admitted patients for this information system. Administrative data like age, sex, province of residence are recorded. Medical data concerning diagnoses of disease, operations performed and consulting physicians are coded and registered.

5.2. Descriptive epidemiological survey of ileostomy patients in the Netherlands.

For this study, data were collected concerning 1,137 patients who obtained an ileostomy in the five-year period from 1979 to 1983 . During this period, data concerning $95 \%$ of all patients admitted to Dutch hospitals were recorded. These data include all large hospitals ${ }^{138}$.

Table 5.1 .

Reasons for obtaining an ileostomy in the 5 year period from 1979 to 1983.

Colitis

-ulcerative colitis

378

- Crohn's colitis

$53 \%$

-colitis not specified

Polyposis coli

$5 \%$

M. Hirschprung.

21

Intestinal carcinoma

22
250

Enteritis

Other intestinal disorders

Trauma

Stoma dysfunction

Other disorders 


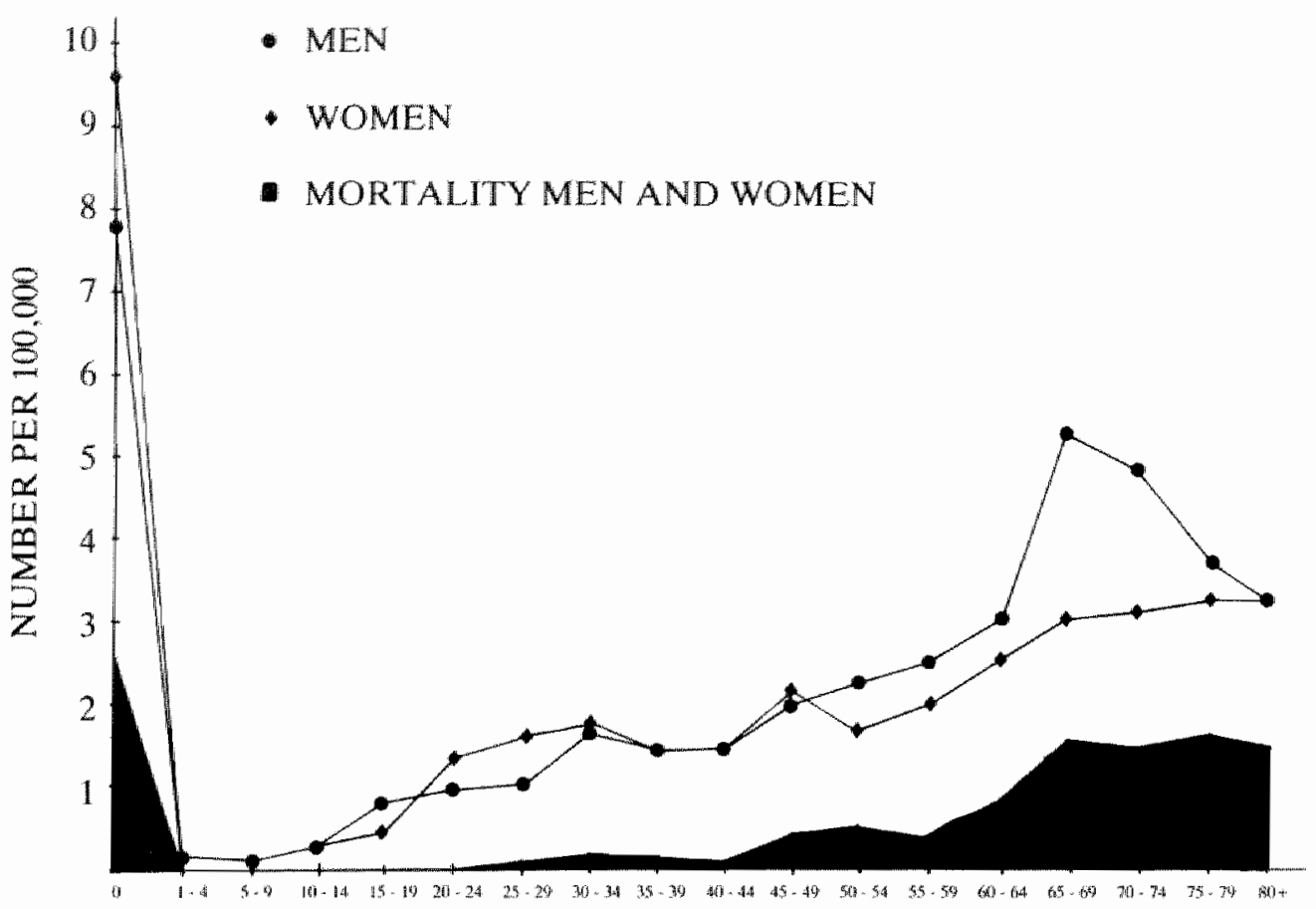

AGE GROUP

Figure 5.1.

The incidence per age group of ileostomy patients (men and women separately) in the Netherlands per 100,000 persons. The incidence of ileostomy patients who died during the postoperative course in hospital per 100,000 persons are given also.

Table 5.1. shows the reasons why these patients have obtained an ileostomy. The majority of the patients suffered from colitis $(33 \%)$. Carcinoma of the small or large intestine $(22 \%)$ and 'other disorders' $(22 \%)$ such as severe enteritis, multiple adhesions, peritonitis, volvulus, were causes for an ileostomy. In addition, other intra-abdominal pathology like ovarian carcinoma, liver and pancreas diseases necessitated an ileostomy.

There was a small group of patients who obtained an ileostomy because of trauma. Some ileostomies needed reoperation because of stoma dysfunction. Finally there was a rest group, with reasons which cannot be fitted into the above-mentioned groups. If the small number $(n=50)$ of reoperations because of stoma dysfunction is ignored, the incidence of ileostomy patients, i.e. the number of patients who obtained an ileostomy per 100,000 inhabitants per year, was 1.6. The incidence was equal for men and women and for the five years separately. There were no differences between the eleven Dutch provinces. 


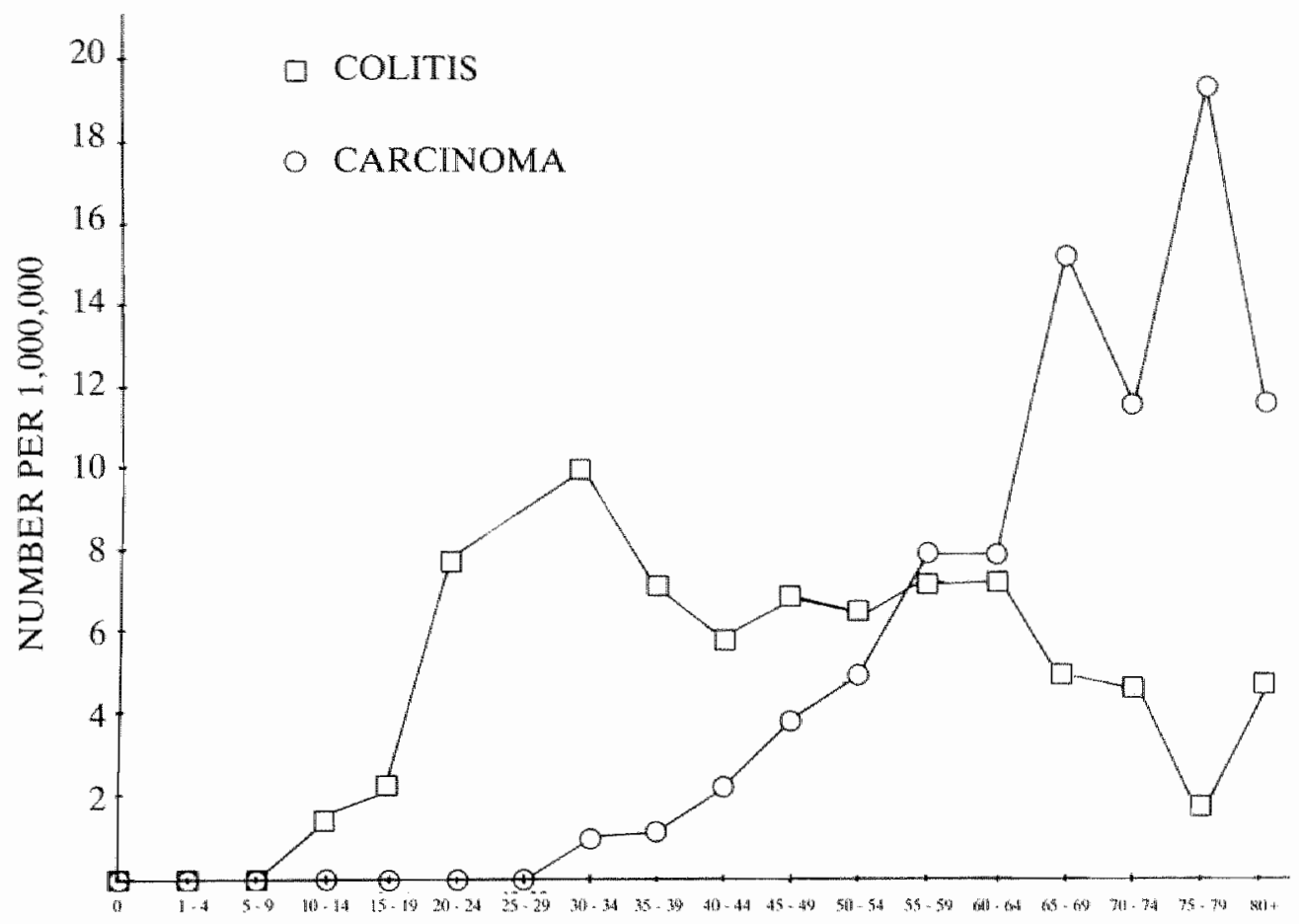

AGE GROUP

Figure 5.2.

The incidence per age group for patients who obtained an ileostomy for colitis and intestinal carcinoma, respectively, per $1,000,000$ persons.

Table 5.2.

Distribution (in \%) of patients according to medical specialisms of original admittance.

\begin{tabular}{lr} 
Internalmedicine & $29 \%$ \\
Gastroenterology & $11 \%$ \\
Surgery & $48 \%$ \\
Pediatrics & $4 \%$ \\
Other & $8 \%$ \\
\hline
\end{tabular}

Table 5.2. shows the percentage of medical specialisms where the patients were originally admitted to. Only half of all patients were seen by a surgeon at first instance.

Figure 5.1. presents the incidence per age group of 5 years. The age group $0-4$ was divided into a group of babies (0 year) and a group from $1-4$ years old.

A relatively large incidence was seen among babies, in the age group of $20-45$ years and among elderly people. This probably reflects the underlying diagnoses, being congenital malformations, colitis and intestinal carcinoma respectively. The incidence of those patients who died during the postoperative course in a hospital for whatever reason, also increased with increasing age.

Figure 5.2. shows the incidence per age group for patients obtaining an ileostomy for 


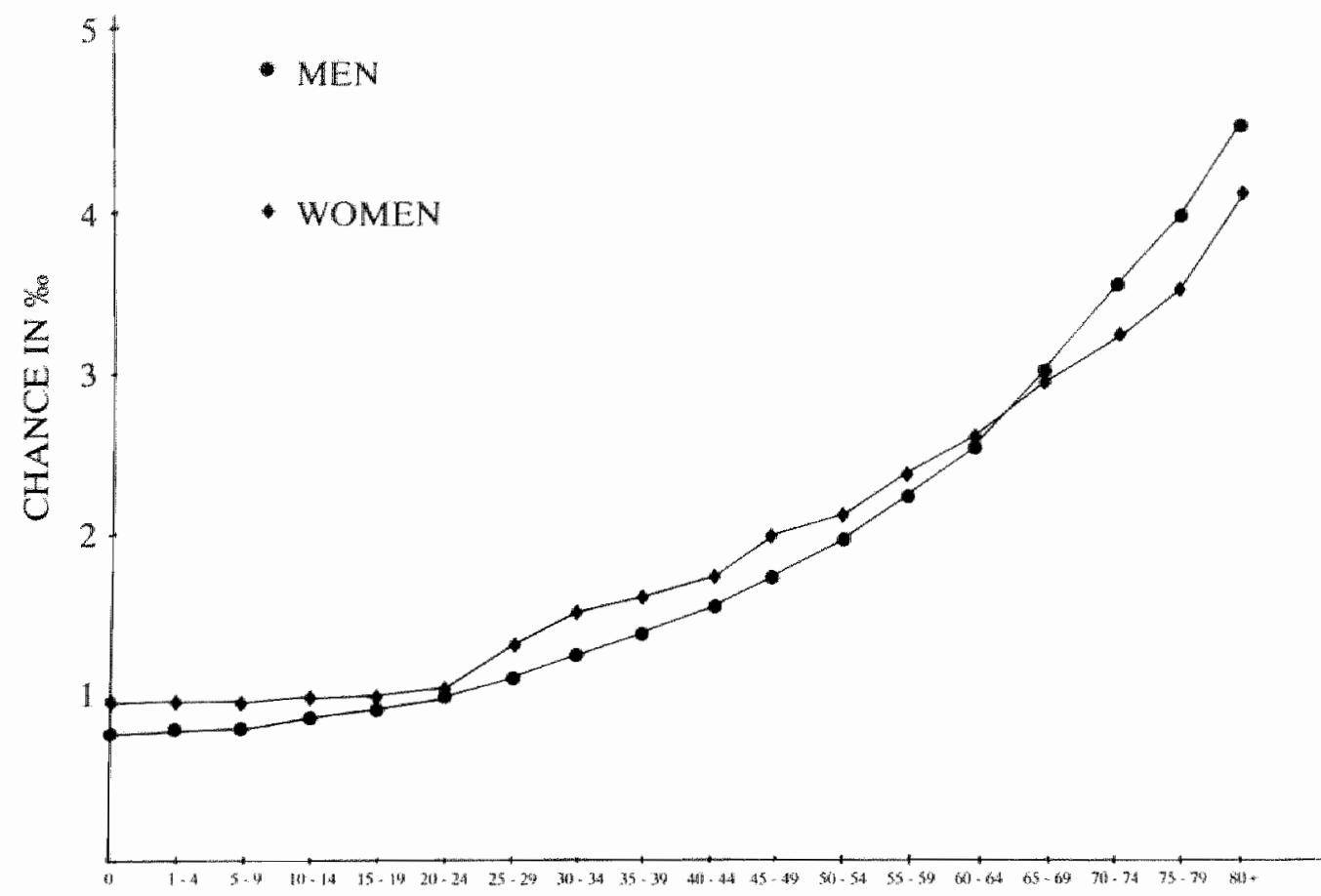

AGE GROUP

Figure 5.3.

The chance to obtain an ileostomy during a person's life.

colitis and carcinoma separately. From the SIG data it was also possible to calculate the cumulative incidence rate, i.e. the chance to obtain an ileostomy during a certain life span. Figure 5.3. showed that this chance was 3 per 1,000 in the first 65 years of 1 ife and 4 per 1,000 in the first 75 years.

Finally a rough estimation of total ileostomy patients can be made by the following calculation. The (point) prevalence was defined as the number of persons affected, i.e. ileostomy patients, in a population divided by the total number of persons within that population at a certain time. In 1983 the prevalence of ileostomy patients in Limburg was 30 per 100,000 persons $(=0.0003)^{148}$. If one assumes that the prevalence of ileostomy patients in the other Dutch provinces was the same as in Limburg then the total number of ileostomy patients in the Netherlands was $0.0003 \mathrm{x}$ the Dutch population. This is approximately 4,000 ileostomy patients.

This number was roughly the same as that estimated by the Harry Bacon Club and Squibb $b^{27,40}$. 


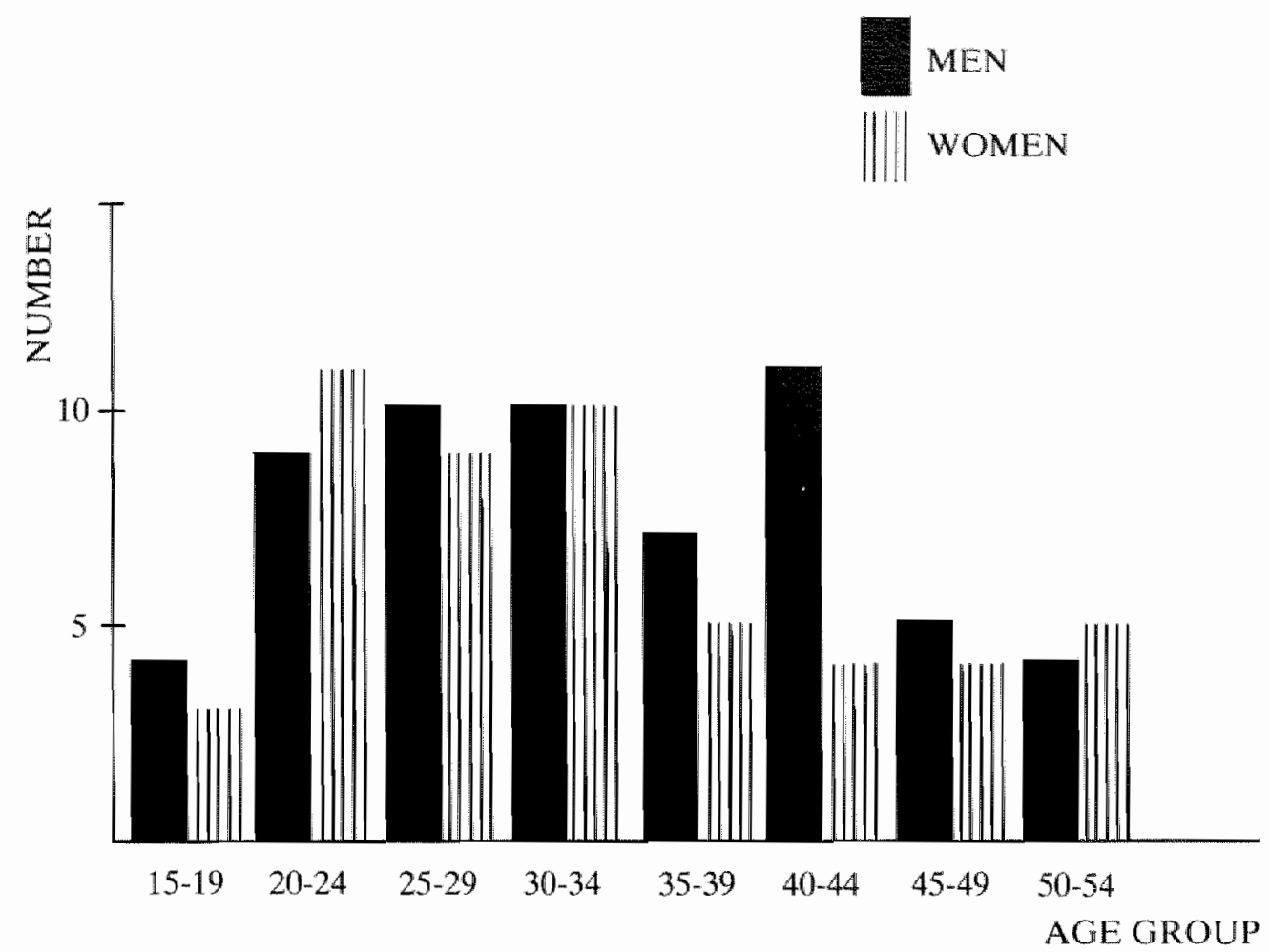

Figure 5.4.

Age and sex distribution of the patients eligible for a continent ileostomy in the 5 year period from 1979 to 1984.

\subsection{Number of patients eligible for a continent ileostomy}

From SIG data of ileostomy patients in the period 1979 to 1983 the number of patients eligible for a continent illeostomy can be estimated.

The following criteria had to be met:

- patients should have obtained an ileostomy after a total colectomy;

- patients should be of the age between 15-55 years. In this age group the patients were assumed to be able to learn how to cope with a continent ileostomy and can easily undergo the operative procedure:

- Crohn's disease or carcinoma, however, should be excluded because of possible recurrence of the disease.

It turned out that 111 of the 1,137 patients were eligible for a continent ileostomy. i.e. 22 per year. The majority of these patients had ulcerative colitis (Table 5.3.).

Figure 5.4. gives the age and sex distribution of these patients. Only $25 \%$ of these 
Table 5.3.

Number of patients in the period 1979 to 1983 eligible for a continent ileostomy.

\begin{tabular}{lr}
\hline Ulcerative Colitis & 86 \\
Polyposis coli & 13 \\
Colitis not specified & 9 \\
M.Hirschprung & 1 \\
Congenital disorder & 1 \\
Trauma & 1 \\
\hline
\end{tabular}

patients were initially seen by a surgeon. The majority consulted the internist (43\%) or the gastroenterologist $(31 \%)$ at first. These specialists should be informed about the possibility for their patients to have a continent ileostomy. In an early stage this alternative could be discussed with selected patients and perhaps could make the idea of a permanent ileostomy less unbearable.

Assuming that the data of the investigated 5 years can be generalized and assuming that the survival of patients with a continent ileostomy was the same as ileostomy patients, the duration of survival can be estimated from the ratio:

$$
\frac{\text { PREVALENCE }}{\text { INCIDENCE }}=\frac{0.0003}{0.000016}
$$

The duration of survival was approximately 18.5 years. By multiplying this figure by 22 new patients per year eligible for a continent ileostomy above-mentioned approximately 400 patients can be considered to be eligible for a continent ileostomy in the Netherlands. 


\section{CHAPTER 6}

\section{EXPERIENCES WITH THE CONTINENT ILEOSTOMY}

\subsection{Introduction}

In the period from January 1982 until October 1985 , when this study was terminated 30 patients obtained a continent ileostomy. In the beginning this procedure was supervised by Prof. N.G. Kock. Surgeons, registrars as well as the nursing staff had to learn the special care of continent ileostomy patients. Gradually, this complex operation became a routine procedure in the operating theatre and its care a routine in the wards.

Only 6 out of the 30 patients came from the region of Heerlen. The remainder came from different parts of the Netherlands. In the majority of cases the patients were informed about the possibility of a continent ileostomy by friends or by other patients. Only a few patients were sent directly by their physicians.

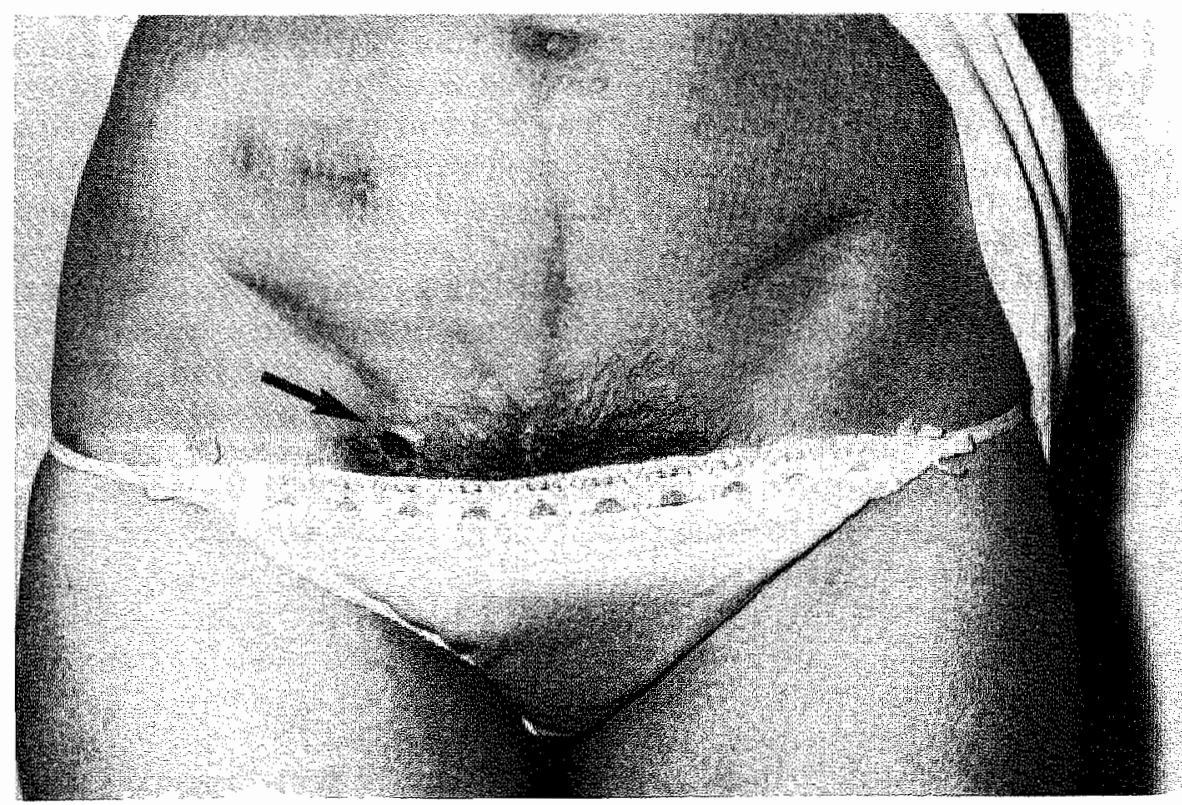

Figure 6.1 .

The continent ileostomy.

The arrow points at the outlet of the continent ileostomy. 


\subsection{Indications}

Almost all continent ileostomy operations were conversions from a conventional ileostomy. As the patients came from all over the country, their complete medical history and previous operations were collected. Two patients had had an ileorectal anastomosis and one an ileoanal anastomosis prior to conversion. The latter was incontinent.

The diagnosis of each patient is summarized in table 6.1 .

Table 6.1.

Diagnoses of the large bowel disease

\begin{tabular}{lr} 
Ulcerative colitis & 12 \\
Polyposis coli & 12 \\
M. Crohn & 2 \\
Colon dysfunction & 4 \\
\hline
\end{tabular}

Ulicerative colitis and polyposis coli were the largest groups. The patients with colonic dysfunction were patients with Hirschprung's disease, rectum or anus atresia with inertia of the colon and motor dysfunction.

Although Crohn's disease was a relative contraindication for this procedure, two patients affected by this disease obtained a continent ileostomy. They received no medical treatment. Active signs of inflammation were absent in these patients for over 5 years. After proctocolectomy the large bowel histology was reviewed and screened on M. Crohn. A definite diagnosis could not be established in 8 additional patients and so far they have been rejected for surgery.

Apart from the diagnosis of large bowel disease, psychological aspects have to be considered as well. The patients must be able to cope with a continent ileostomy and should have the discipline to empty the reservoir several times a day. Prior to their ultimate decision all information concerning the continent ileostomy was given. Not only the advantages, but also disadvantages such as possible complications of the procedure were discussed. At least one meeting was arranged with a patient who already had obtained a continent ileostomy, to talk about his or her experiences prior to the operation.

\subsection{Technique of operation}

The operative technique described below, is the procedure chosen at the "De Wever" Hospital.

The operator is on the patient's left-hand side. Nearly all patients are converted from a conventional ileostomy to a continent ileostomy. The conventional ileostomy is excised from the skin, mobilized and closed. A midline incision in the lower abdomen is performed. Routine inspection of the abdominal cavity is carried out and the small bowel length is measured from Treitz" ligament. The small bowel is now delivered outside the abdomen. The open end of intestine is placed towards the patient's head end. A segment of $45 \mathrm{~cm}$ terminal ileum is measured (figure 6.2.). A segment $10 \mathrm{~cm}$ is chosen from this to form the nipple valve. From this segment the peritoneum of the 
mesentery is removed on either side together with a part of the mesenteric fat, leaving the main vessels intact (figure 6.3.).

Proximal to this segment $30 \mathrm{~cm}$ of the ileum is folded into a "U" with the terminal segment directed towards the cramium. The bottom of the "U" is directed to the left-hand side of the patient. This positioning of the gut is important for later manoeuvres, which allow the pouch to be positioned in the lower part of the abdominal cavity and allows the mesentery supplying the terminal ileum to be sutured to the right parietal peritoneum.

The reservoir construction can be started. The intestine (both $15 \mathrm{~mm}$ segments) is split open by diathermy at the anti-mesenteric border (figure 6.4.) and the incision is continued for about $3 \mathrm{~cm}$ on the proximal segment, in order to separate the outlet from the inlet when the reservoir is accomplished. The legs of the "U" are now sutured with one layer continuous atraumatic Vycril $3-0$. The intussuscepted valve is now constructed. The bowel wall is grasped by an Allis-clamp through the open lumen of the terminal unsplit ileal segment and is intussuscepted into the lumen of the future reservoir. The intussuscepted nipple valve should be $5 \mathrm{~cm}$ long. The nipple position maintained by application staplers with the GIA without knife through the intussuscepted intestine (figure 6.5.). Two rows are placed along the mesentery. Then one or two rows are placed along the antimesenteric border.

The intestinal plate is folded up and the reservoir is closed by use of continuous inverting Vycril ${ }^{\circledR 3}$ 30 sutures. The sutures begin at the apex of the future reservoir and continue towards the corners. The intussusception is secured by supplemental Vycril sutures placed around the circumference of the intussuscepted outlet, fixing the reser. voir outlet.

The valve function of the nipple and the competence of the suture line are then tested by inserting a catheter into the reservoir and injecting $100 \mathrm{ml}$ air while clamping the afferent ileal loop (figure 6.6.). The catheter should be easily put into the nipple valve and there should be no leakage of air through the outlet after removal of the catheter. The air is removed by inserting the catheter again. An opening in the skin is made just above the pubic hairline. The external fascia is cross-split. By blunt finger dissection a channel is made through the rectus muscle and the peritoneum. Before the terminal segment of the ileum is pulled through, interrupted Vycril ${ }^{\circledast 2}$ sutures are placed in the seromuscular coat of the lateral aspect of the reservoir and into the posterior rectus fascia, thereby anchoring the reservoir to the abdominal wall. The parietal peritoneum around the inner opening of the ileostomy channel is excised to achieve firmer fixation of the reservoir to the rectus muscle.

After the terminal segment of the ileum has been pulled through the abdominal wall, the medial aspect of the reservoir is also fixed against the rectus fascia with isolated sutures (figure 6.7.). The space lateral to the reservoir is closed by suturing the parietal peritoneum to the mesentery of the reservoir.

Excess terminal ileum above skin level is resected. The ileostomy is constructed flush with the skin, using muco-cutaneous sutures. Then a temporary loop ileostomy is constructed (figure 6.8.). The place of the conventional ileostomy can be used. A loop of ileum as distal as possible is selected a point which will not put any tension on the reservoir. A small hole is made in the mesentery at the apex of the loop and a tape is passed through the hole. The loop is drawn through the abdominal wall and directed in such a way that the mesentery is not twisted. The tape is then replaced by a plastic rod, which rests on the abdominal wall on either side of the stoma. As this stoma is only temporary it is not sutured to the rectus sheath. Then the wound of the midline 


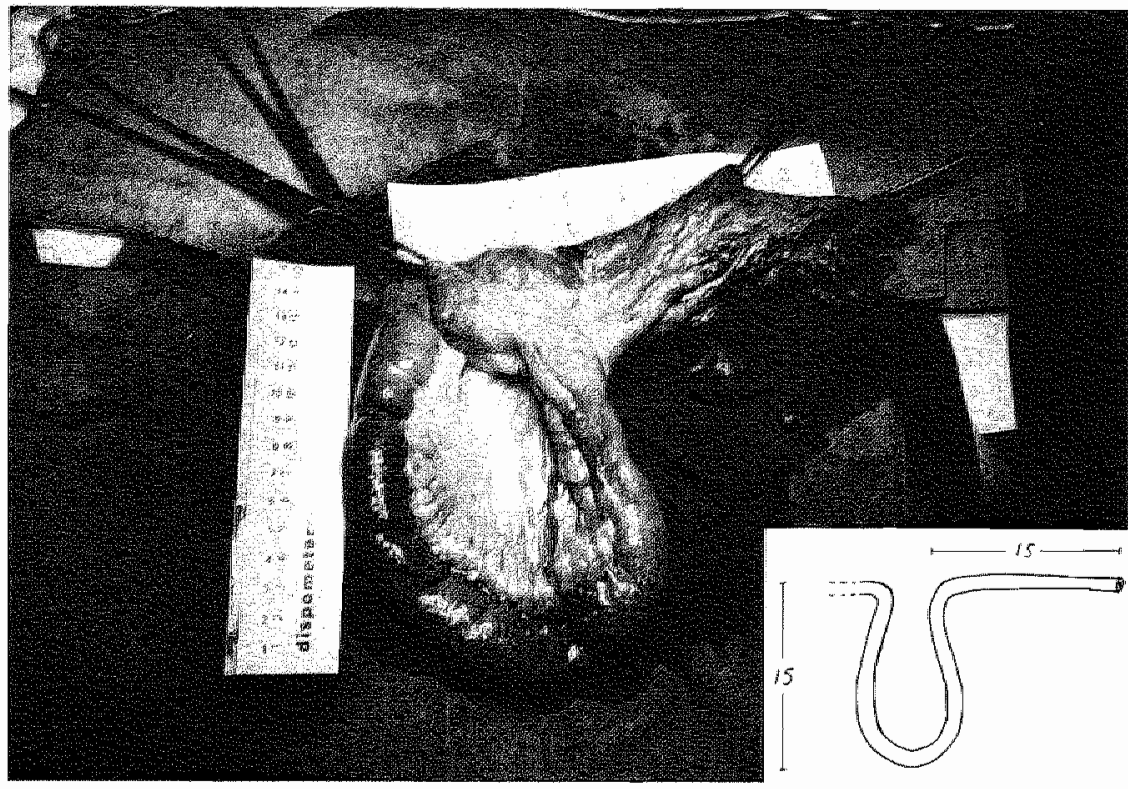

Figure 6.2.

A segment of $45 \mathrm{~cm}$ terminal ileum is measured (see also inset).

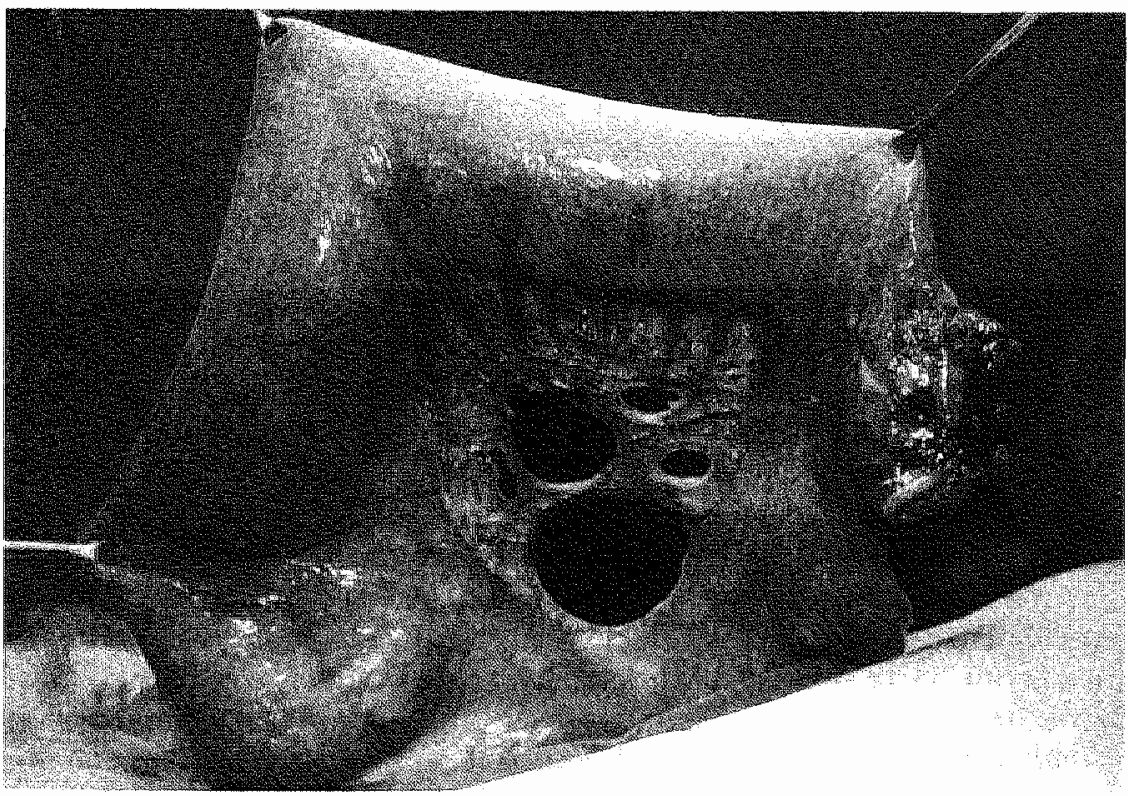

Figure 6.3 .

The mesentery of the segment which is chosen to form the nipple valve, is denuded from peritoneum and mesenteric lat as much as possible without jeopardizing the blood supply. 


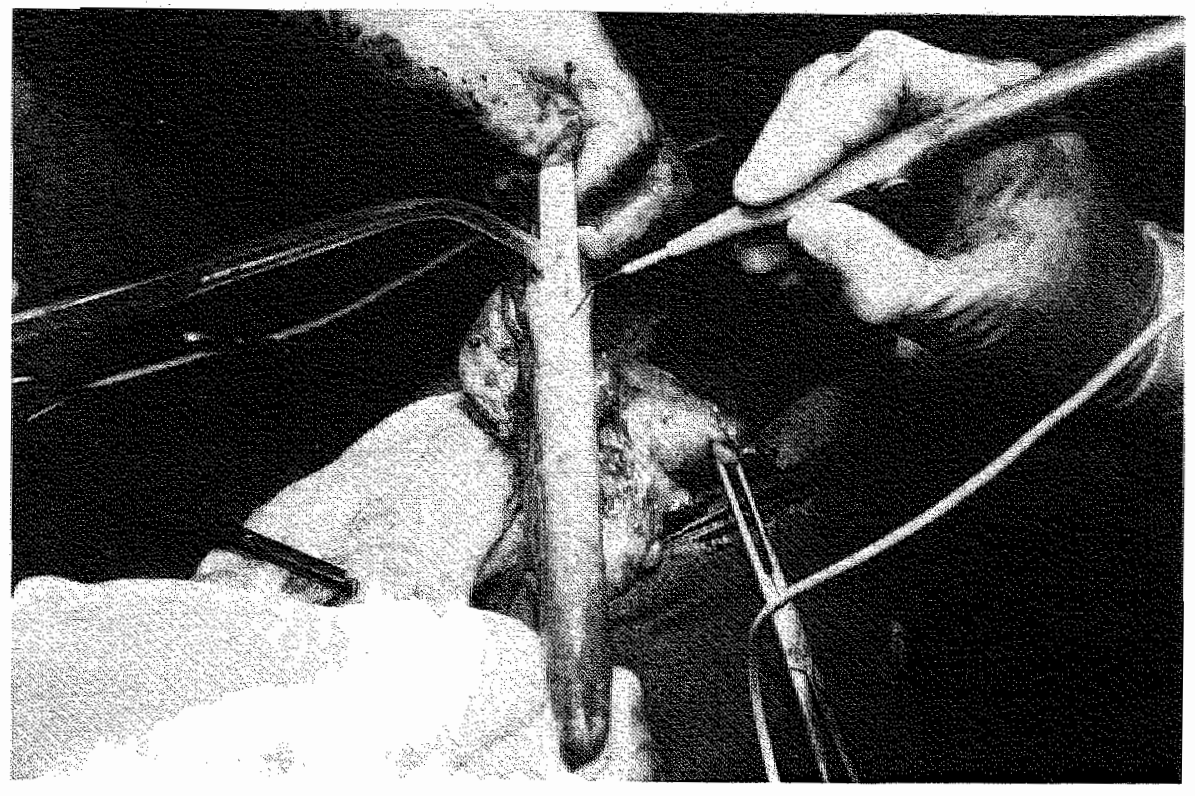

Figure 6.4 .

The mesentery is split open at the anti-mesenteric border. A plastic rod with a longitudinal groove is placed in the bowel lumen to facilitate diathermy cutting.

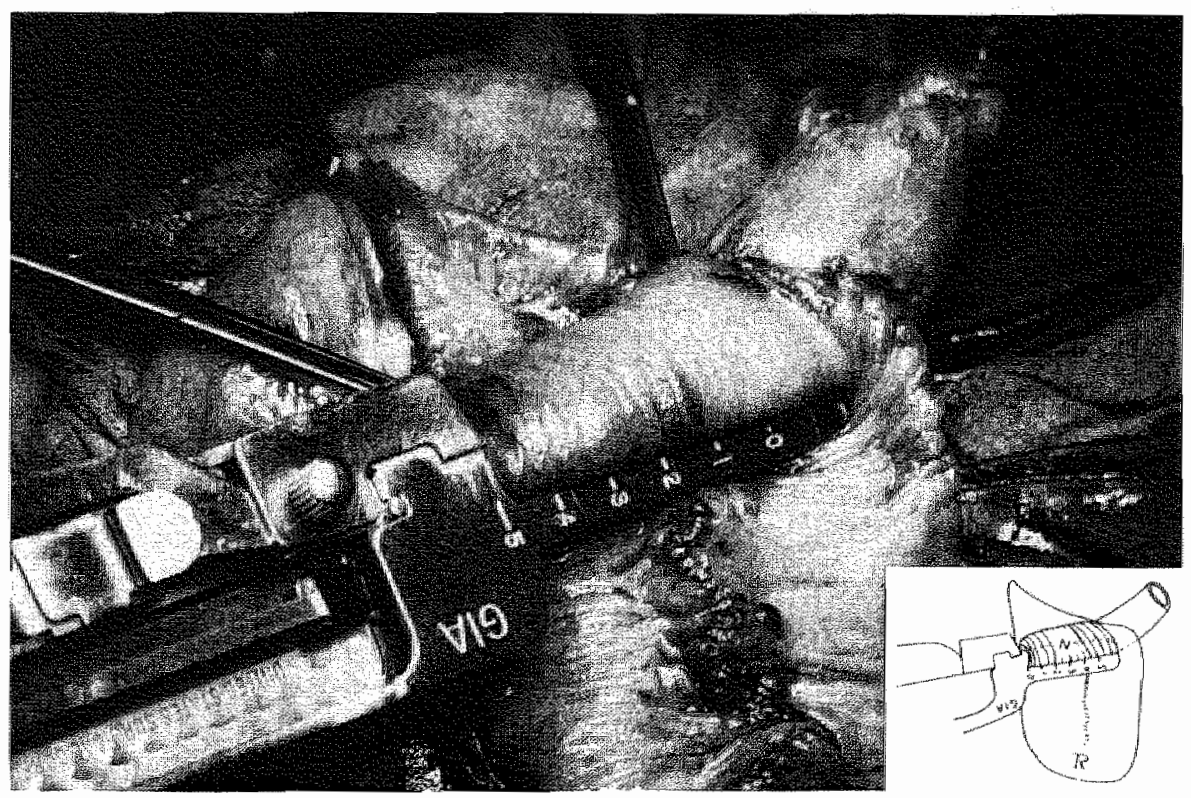

Figure 6.5.

Application of GIA staples through the intussuscepted intestine $(5 \mathrm{~cm})$. Inset: $\mathrm{N}=$ nipple, $\mathrm{R}=$ reservoir. 


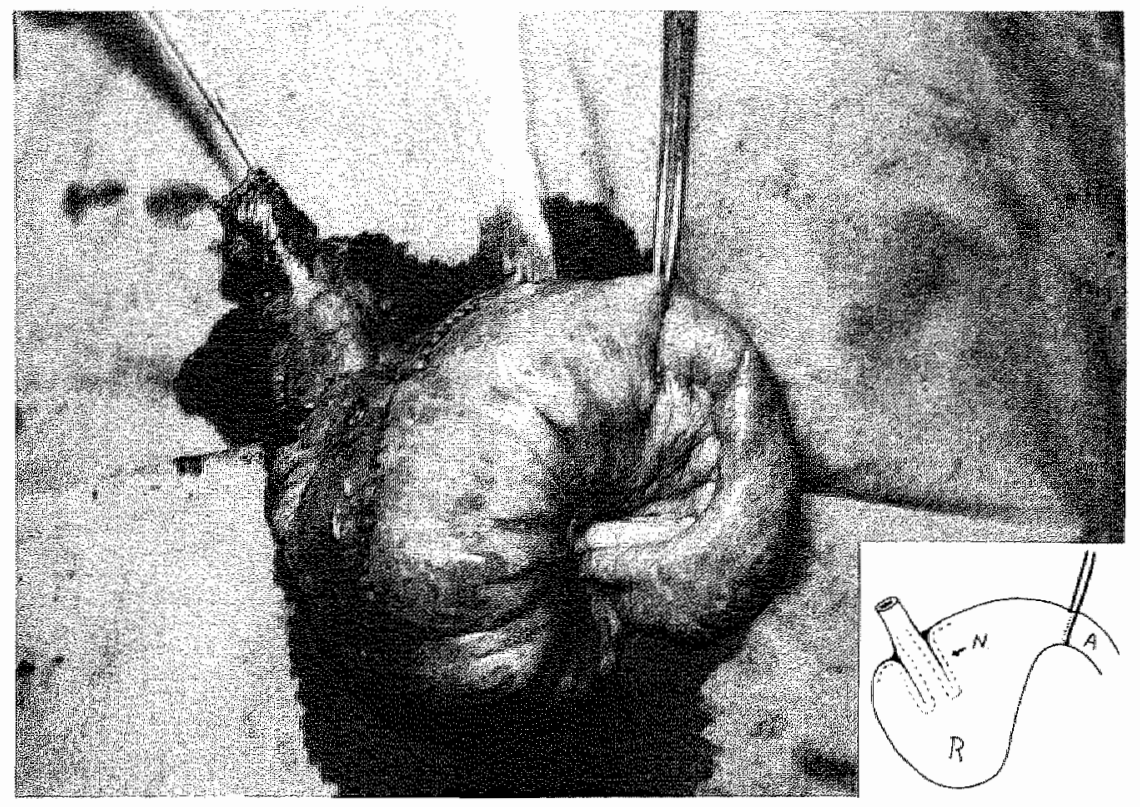

Figure 6.6.

The nipple valve (left) is tested by injecting $100 \mathrm{ml}$ air in the reservoir after clamping the afferent ileal loop (right).

Inset: $\mathrm{N}=$ nipple, $\mathrm{R}=$ reservoir, $\mathrm{A}=$ afferent ileal loop.

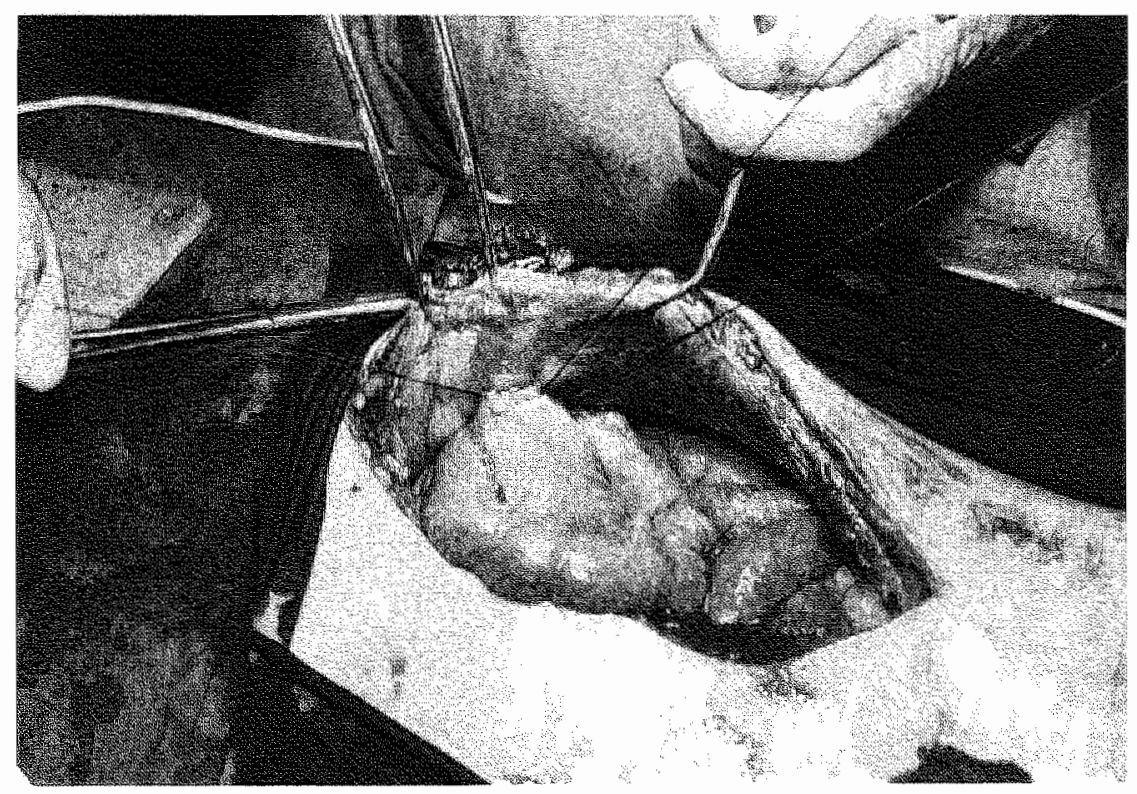

Figure 6.7 .

The reservoir is fixed against the abdominal wall. 

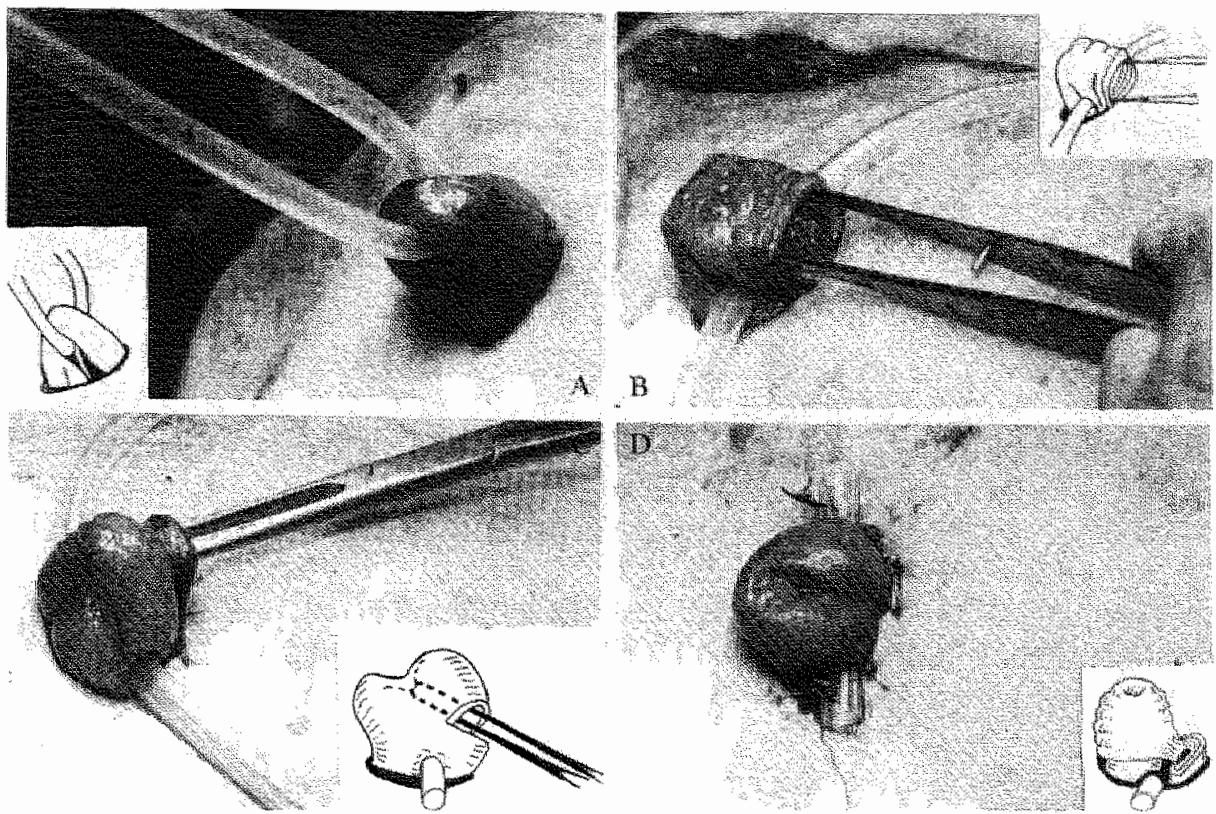

Figure 6.8 .

The construction of the loop ileostomy (see also inset).

A. A loop of intestine is drawn through the abdominal wall.

B. A transverse incision is made at the base of the distal limb to open the intestine.

C. The proximal limb is inverted with an Allis-clamp.

D. The edges of the mucosa are sutured to the skin edge.

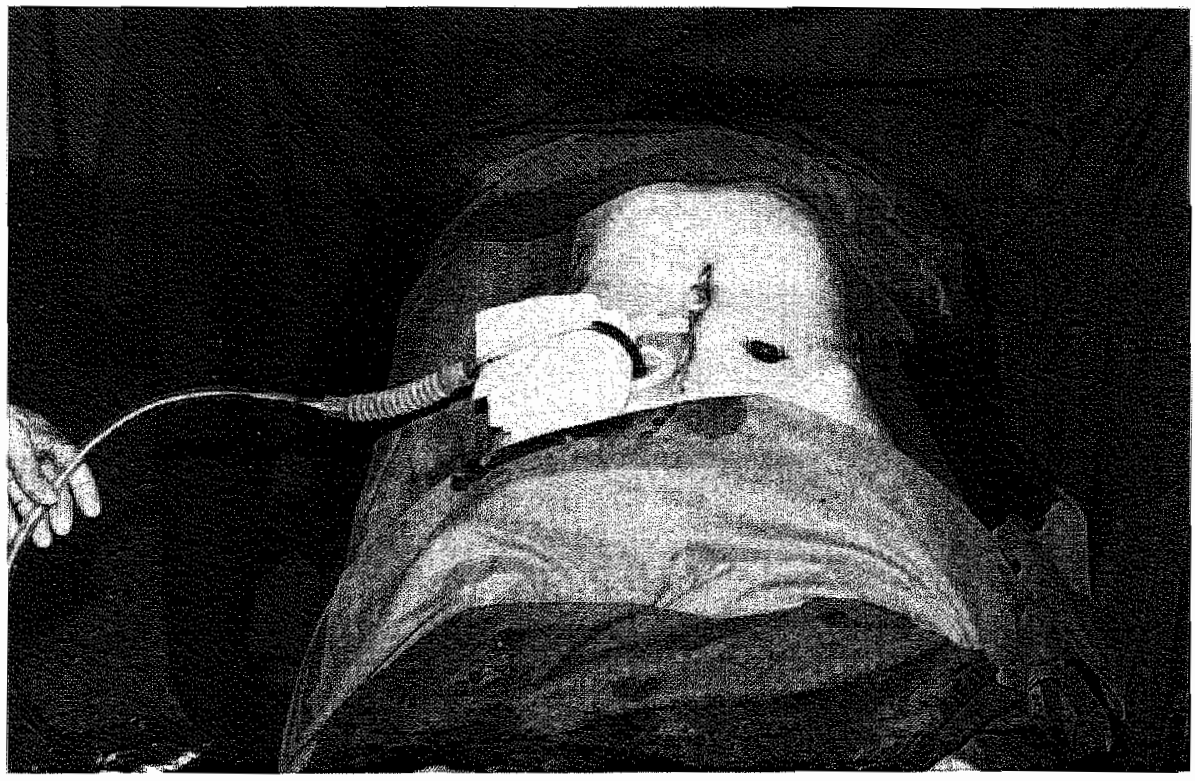

Figure 6.9.

End result. Left : the continent ileostomy with a tube in it draining into a plastic bag. Right : the loop ileostomy. 
abdominal incision will be closed. Before doing this, a catheter with a diameter of $10 \mathrm{~mm}$ is inserted in the reservoir. The catheter tip has to be positioned on the bottom of the reservoir. A mark should be placed on the point where the drain leaves the abdominal wall. The ileostomy catheter is fixed firmly to the flange of a stomahesive by sutures, that is applied to the abdominal wall to prevent slippage out of the reservoir with manipulation. In this way the sutures will not cause any pain when there is any traction on the drain. The drain is connected to a wide-bore tube draining into a plastic bag (figure 6.9.).

Finally, the loop ileostomy is opened. A transverse incision is made on the antimesenteric border near the base of distal limb of the knuckle of bowel. An Allis-clamp is inserted into the apex of the proximal limb. This is then brought to the surface, thereby everting the proximal limb. The edges of the mucosa are then sutured to the skin edge. The ileostomy appliances are subsequently put in place using a transparent bag, so that the colour of the stoma can be controlled.

Antibiotic prophylaxis is given intravenously at the induction in narcosis, for 24 hours. Tobramycin is administered in the dose of $3 \times 80 \mathrm{mg}$ and metronidazole in the dose of $3 \times 500 \mathrm{mg}$.

\subsection{Postoperative management}

Thrombosis prophylaxis is given. Subcutaneous low dose heparine is started on the evening before operation. If a history of thrombosis or pulmonary embolism is present acenocoumarol (Sintrom mitis ${ }^{\circledR}$ ) will be given. The patient is mobilized on the first postoperative day. Nasogastric aspiration is kept in place until peristalsis begins and the stomach retention is less than $200 \mathrm{ml}$ after 6 hours pinch off of the nasogastric tube. In most cases this is on the second postoperative day.

The patient, previously kept on parenteral fluid therapy is allowed to start drinking 30 $\mathrm{ml}$ per hour. The next 2 days the amount of fluid gradually increases. At the same time intravenous fluid therapy is reduced. On the fifth postoperative day normal food is given.

Special care must be given to draining the reservoir. As previously mentioned the drain is sutured to the flange of a Stomahesive ${ }^{\text {i. }}$. The drain must leave the stoma outlet perpendicular to the abdominal wall, for otherwise pressure necrosis of the outlet may arise. This position can be maintained by diverting the drain over a roll of gauze. A $\mathrm{U}$-shaped drain facilitates this. The drain is connected to a short wide bore tube with a bag. This eliminates the possibility of a water siphon, which prevents good drainage in the bag. This must be regularly controlled. The drain is carefully flushed with $20 \mathrm{ml}$ saline 4 times a day and once during the night for a period of 2 weeks. At the same time the colour of the stoma and the position of the drain in the reservoir are checked.

Two weeks after operation the drain can be removed. The reservoir can be emptied by carefully inserting a catheter 6 times a day. When the patient is able to manage this himself, he will be discharged from the hospital. After 10 days the stitches are removed. At discharge from hospital the patient receives a codicil stating that he has obtained a continent ileostomy. A schematic drawing of the reservoir is also given. This is necessary as this procedure is not yet very familiar to physicians in the Netherlands. Moreover, some patients come from remote parts of the country. If the patient is involved in an accident and becomes unconscious, regular catheterizing of the reservoir 
has to be continued, for otherwise it may become disastrous for the patient. An appointment for a visit to the outpatients" department 3 weeks after discharge is made. Two catheters are given together with a $60 \mathrm{ml}$ syringe for rinsing the reservoir. A prescription for ileostomy appliances for the loop ileostomy and extra catheters are also given.

After approximately 3 months an admission to the hospital is arranged to close the loop ileostomy. Antimicrobial prophylaxis and thrombosis prophylaxis are the same as in the former operation. The loop illeostomy is closed as a local procedure without laparotomy.

Postoperatively the patient is kept on parenteral fluid therapy until nomal fuid intake is possible. The patient is kept on fluid regimes for 7 days. On the 8 th postoperative day food which can be easily digested is given. After 2 weeks, normal food can be eaten. Continuous stoma drainage starts after the operation. The drain must be fixed in the method above-mentioned. Every 2 hours the drain must be flushed with $20 \mathrm{ml}$ saline for one week. On the 8 th postoperative day the drain is clamped and every
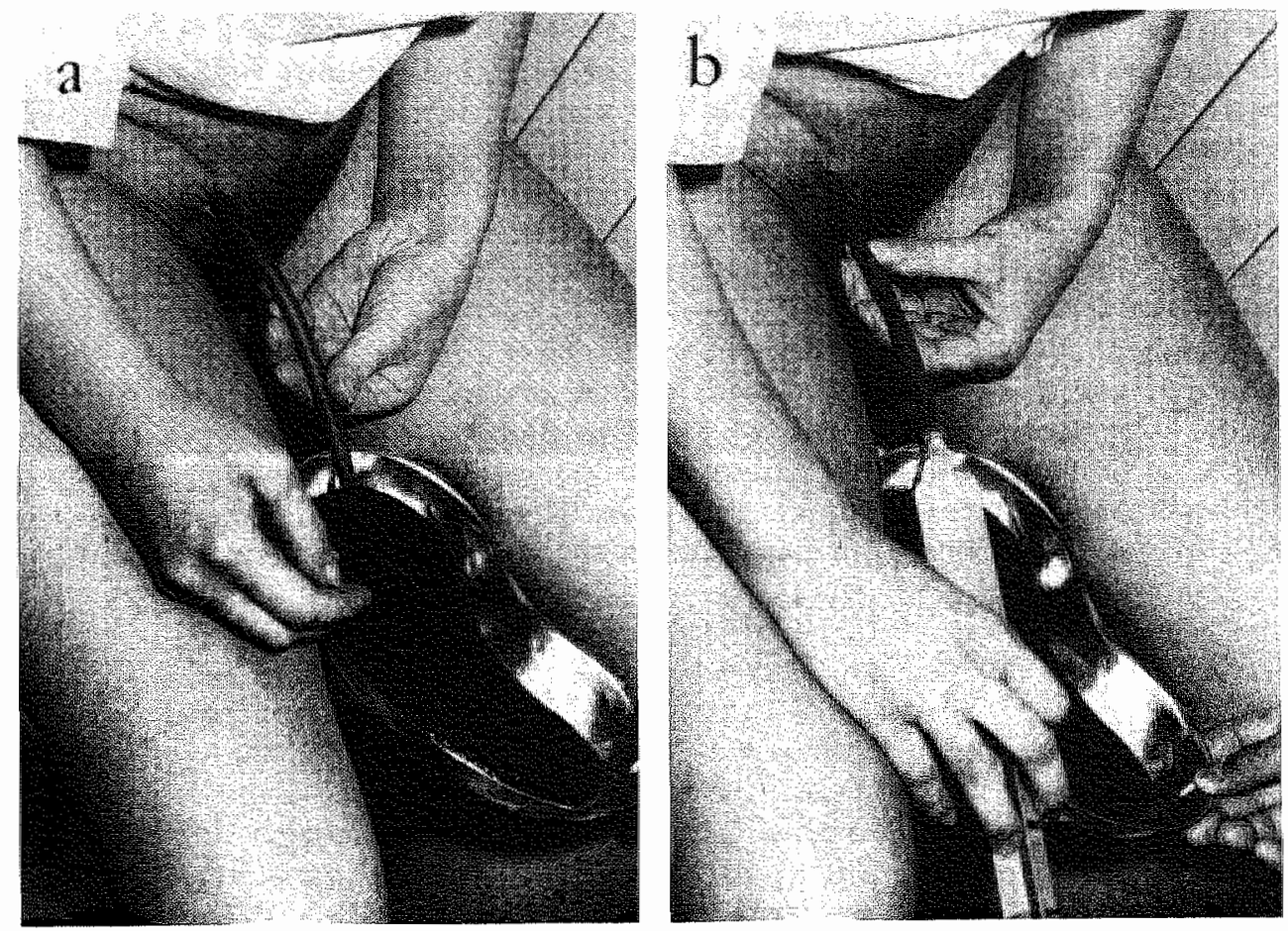

Figure 6.10 .

Left : emptying the reservoir by inserting a catheter.

Right: rinsing the reservoir with water. 
4 hours the clamp is removed and the reservoir flushed with $20 \mathrm{ml}$ saline and allowed to drain. On the 11 th postoperative day the drain is removed and catheterizing can be started every 4 hours. Meanwhile, the stitches are removed. From then on the reservoir can be emptied 4-5 times a day, while flushed with $40 \mathrm{ml}$ saline. After two weeks the patient is discharged from hospital.

No special diet is given. A list of food that can cause obstruction of the outlet, or food that can cause hindrance, odour or gas formation is given. The patient is advised to drink enough (11 to 2 liters per day), to eat regularly and to chew well.

As the patients come from all over the country, they are not controlled regularly. They are informed about the early symptoms of possible complications and advised to come whenever problems arise.

Information concerning the continent ileostomy is sent to the patient's physicians.

\subsection{Results}

Eleven men and nineteen women obtained a continent ileostomy. Their average age was 32 years at the time of operation (range 18-55 years). The average period of follow up in this study was 21 months (range 1-44 months).

No operative lethality was recorded.

One patient died 2 years after having obtained a continent ileostomy and in 2 patients the continent ileostomy was removed. The remaining 27 patients are continent.

The patient who died underwent a colectomy with ileo-rectal anastomosis because of polyposis coli. An adenocarcinoma recti (Dukes C) appeared 24 years later. He obtained a conventional ileostomy after rectum amputation and radiotherapy was given. After a 3 years' disease-free interval this ileostomy was converted to a continent ileostomy. Two years after obtaining the continent ileostomy the patient died of metastasis and radiation enteritis.

The continent ileostomy had to be removed in one continent patient after 10 months because of recurrence of Crohn's disease in the reservoir. Another patient was admitted to a hospital elsewhere because of a fistula simultaneously with an illeus. Lack of experience with the continent ileostomy procedure resulted in the decision to remove it. None of the patients used external appliances. The patients emptied their reservoirs 3 to 4 times a day. A simple dressing (Hansapor ${ }^{(3)}$ ) was used to protect the outlet.
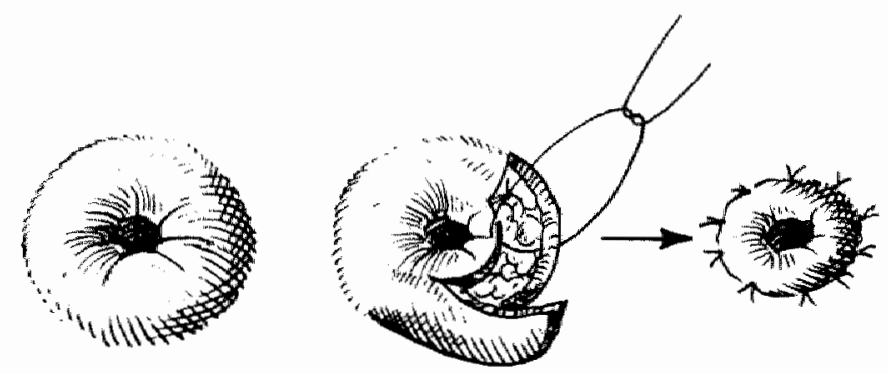

Figure 6.11.

Excision of redundant mucosa and resuturing the muco-cutaneous junction. 
Mucus excretion from the outlet of the continent ileostomy was to a certain extent a disability for some patients. Abundant excretion can be caused by eversion of excessive mucosa. It can be corrected by diathermic excision of the redundant mucosa and resuturing the muco-cutaneous junction (figure 6.11.). In two patients this was done successfully.

\subsection{Complications}

The complications of the 30 patients who obtained a continent ileostomy can be divided into complications related to the valve, the reservoir and the loop ileostomy on the one hand and those related to any major operation on the other hand, herein called non-related complications. Table 6.2 . give all complications that occurred in $\mathbb{1} 3$ patients.

Table 6.2.

All complications of the continent ileostomy operation that occurred in this study. VALVE COMPLICATIONS RESER VOIR COMPLICATIONS

Valve necrosis

Slipped valve

Fistula Recurrence M.Crohn

Valve revisions

Prolapse

\section{LOOP ILEOSTOMY COMPLICATIONS}

Prolapse
Stenosis at suture site
Blleeding
Uremia

\section{NON RELATED COMPLICATIONS}

$\begin{array}{ll}\text { Intestinal obstruction } & 5 \\ \text { intra-abdominal abscess } & 1 \\ \text { Pneumothorax } & 3 \\ \text { Pulmonary embolism } & 2 \\ \text { Deep venous thrombosis } & 1\end{array}$

A majority of the complications related to the valve of the continent ileostomy. This finding corresponds with experiences in other countries ${ }^{29,33,57,86,88,120,134,137 .}$.

Two patients developed necrosis of the valve. Both had to be replaced, one during the primary operation, the other after one month. Both patients had the valve constructed on the cecum, in fact a continent cecostomy. Besides valve problems, they had difficulties in emptying their reservoirs. They finally obtained a continent ileostomy. These problems with the continent cecostomy were also reported by Kock et al..$^{92}$. Four patients needed reoperations because of slipped valves. This resulted in incontinence and difficulties with inserting the catheter. In 2 patients this complication was due to negligence in emptying the reservoir during a whole day. The nipple valve was repaired by intussusception of the outlet segment and resuturing it with rows of staples 

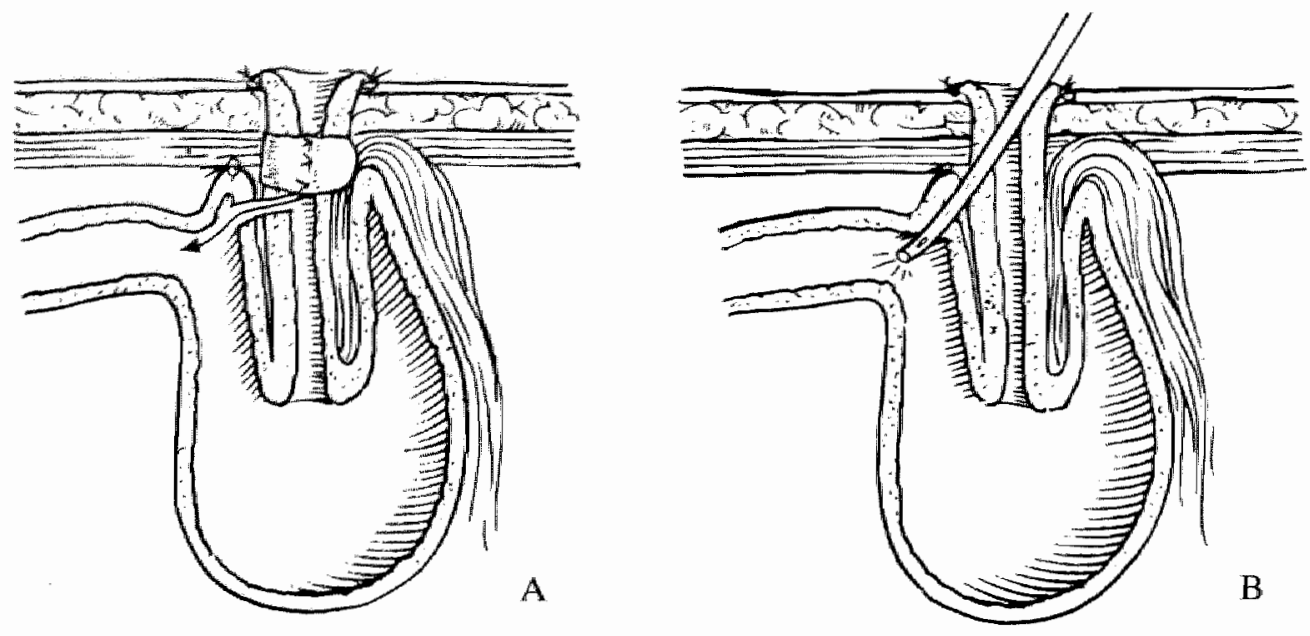

Figure 6.12.

A. Fistula in relation to the Marlex ${ }^{3}$-mesh.

B. Fistula due to mechanical trauma of inserting the catheter.

or the intussusception was made from the efferent loop that was afterwards interposed on the reservoir.

In three patients fistulas of the valve were found. One patient developed a fistula in relation to the Marlex mesh, which was used to secure the intussusception of the nipple (figure 6.12.A).

Only by removing the foreign material the fistula healed.

Fortunately, the patient remained continent. The use of the Marlex mesh has been abandoned ever since. One patient had a fistula on the base of the intussuscepted part of the valve. This was probably due to the mechanical trauma of inserting the catheter. The patient complained of incontinence and difficulty in inserting the catheter. A laparotomy was necessary to close the hole in the nipple and continence was achieved (figure 6.12.B). One continent ileostomy was removed in another hospital because a fistula occurred simultaneously with an ileus. Unfortunately, no further data were available concerning this patient.

Two patients became incontinent postoperatively. Manometrical measurements of the valve failed to show a clear high pressure zone in the outlet. Both patients had a history of long standing constipation which resulted in a dilated ileum as could be found during operation. The dilated valve was narrowed by resection of a longitudinal wedge (figure 6.13.). Both patients were continent afterwards.

Prolapse was found in one patient and required reoperation.

Before the loop ileostomy was introduced half of the patients had complications related to the valve. Since the use of the loop ileostomy to protect the continent ileostomy during the first months, only 2 out of 20 patients had had valve-related complications. These complications were a fistula because of catheter perforation and a valve revision because of a dilatted valve.

Unfortunately, four complications related to the loop ileostomy were noticed. A prolapse of the loop ileostomy was reduced at the time the loop ileostomy was to be 

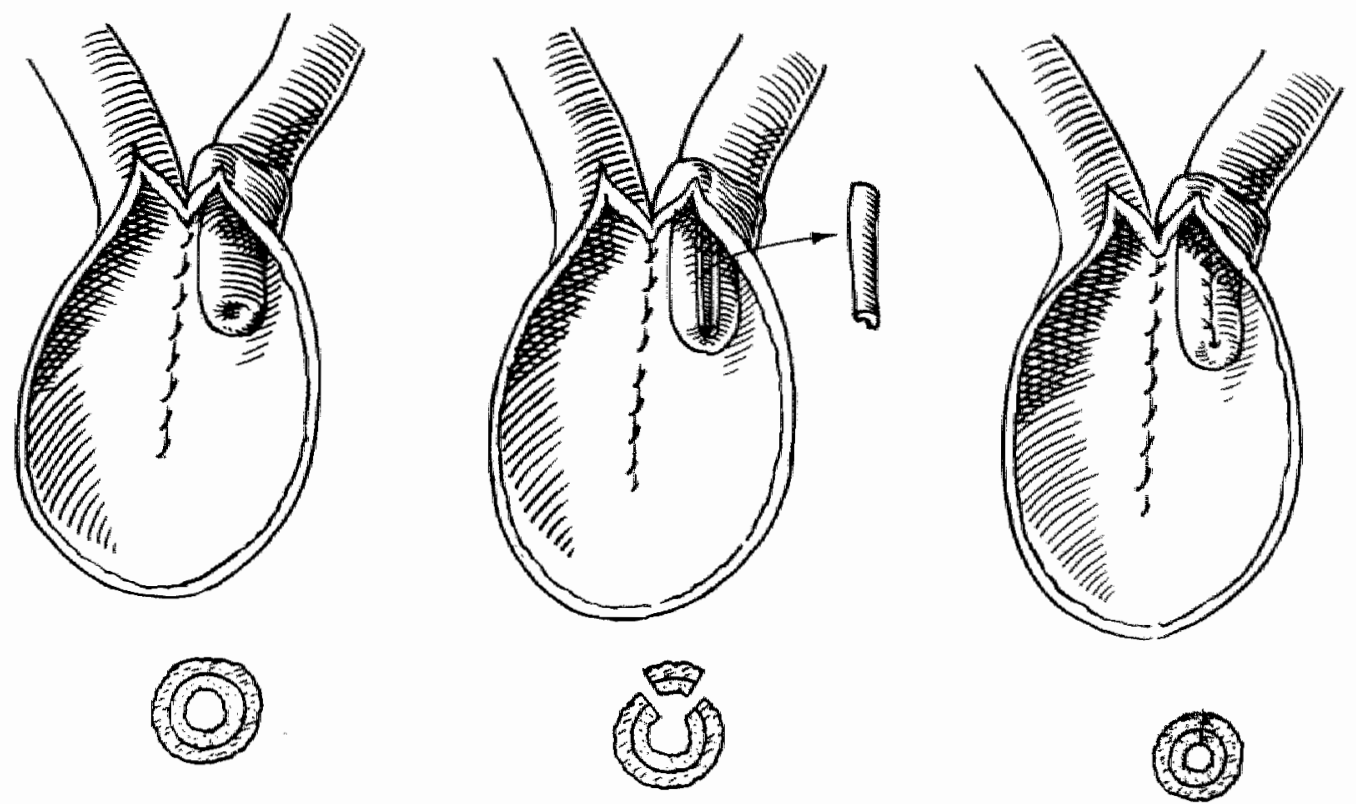

Figure 6.13.

The dilated valve is narrowed by resection of a longitudinal wedge.

closed. Stricture following closure of a loop ileostomy needed a stricturoplasty, i.e. the stricture was opened in the long axis and closed transversely.

During the procedure of closing the loop ileostomy a very severe bleeding from the inferior epigastric artery occurred and this could only be managed by performing a laparotomy and ligating the vessel. Uremia was found in one of the older patients (55 years old) because of extensive fluid loss from the loop ileostomy that was placed rather proximal on the ileum. This was corrected by intravenous fluid therapy.

Non-specific ileitis of the reservoir was seen in three patients. The diagnosis of the large bowel disease was ulcerative colitis in all patients. They complained of excessive fluid loss and abdominal cramps. If the fluid loss was excessive the patient had to be admitted to hospital for one or two weeks. Continuous drainage and rinsing of the reservoir with metronidazole was needed. Oral metronidazole was also administered. If the symptoms were less severe, the patient could manage himself at home by frequently emptying the reservoir and taking metronidazole.

As already mentioned the reservoir had to be removed in one patient because of recurrence of Crohn's disease in the reservoir.

The patient who was previously continent was very disappointed.

The number of reoperations due to intestinal obstructions was relatively high. This may not be surprising taking into account that all patients had had several abdominal operations previous to the continent ileostomy operation. In five patients a laparotomy was needed for adhesiolysis. These patients had 2 to 16 abdominal operations before they obtained a continent ileostomy.

Another non related complication was an intra-abdominal abscess that needed to be drained in the postoperative course. 
A pneumothorax occurred in 3 patients after subclavian vein catheterizing for intravenous fluid administration. Only when parenteral nutrition was needed or peripheral veins were difficult to cannulate such a catheter was inserted. The relatively high incidence of pneumothorax in these patients cannot be accounted for.

Thrombo-embolic complications were treated successfully with heparin intravenously followed by oral anticoagulation therapy.

\subsection{Cost analysis}

In the following analysis a survey will be given of the cost consequences of obtaining a continent ileostomy. The cost analysis is based on the assumption that a person has a conventional ileostomy replaced by a continent ileostomy. By constructing a continent ileostomy additional costs have to be made at the time of performing the operation. On the other hand, annual expenses of ileostomy appliances, skin problems etc. rellated to a conventional illeostomy are saved.

In this paragraph financial aspects concerning the costs of a conventional ileostomy are compared with the costs of obtaining and maintaining a continent ileostomy. This comparison should be based on real costs of the two alternatives. In this calculation the real costs are estimated using the existing price system such as tariffs and fees.

Table 6.3. presents the expenses per year of a person with conventional ileostomy, including stoma appliances, extra laundry and estimated extra costs, when skin irritation appear. The costs of ileostomy appliances are based on the economical user using 2 stoma bags a day, 2 stomahesives a week and 1 tube of a skin protective paste a month $^{40}$.

A patient with a conventional ileostomy spends an average of Dfl. 4,025 per year during life time.

Table 6.3.

Expenses of ileostomy patients per year.

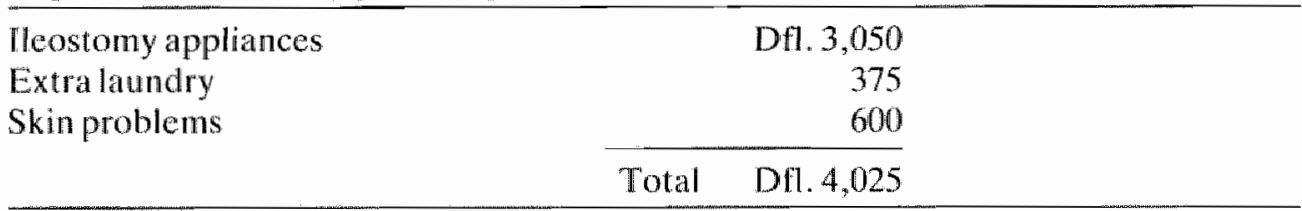

The costs of obtaining a continent ileostomy are Df1. 13,859 as presented in table 6.4. These include consultation fees at the outpatients' department, prices of preoperative investigations such as blood tests, $\mathrm{X}$-ray examination of the chest, electrocardiogram and stomascopy, fees of operation team and use of operation room, 30 days staying in hospital and additional costs of postoperative blood tests.

The costs are based on prices in 1984 as calculated in the "De Wever" Hospital.

Transport charges for patient and relatives are computed, because most patients do not come from the neighbourhood of Heerlen. On average they have to travel $200 \mathrm{~km}$. 
Table 6.4 .

Costs of obtaining a continent ileostomy.

Fees visits outpatients ' department

Preoperative investigations

Postoperative investigations

Fees conversion operation

Fees closing loop-ileostomy operation

30 days stay in hospital

Tramsport charges
Dfl. $\quad 59.65$

270.35

$400 .--\cdots$

2,223

492 . -

9,414

1,000 .

Total Dfl.13,859.-

When the operation was successful, only one out-patient control took place.

After conversion to a continent ileostomy a patient only needs a catheter to empty his reservoir. Assuming that every 2 weeks a new catheter is used, total costs will be Dfl. 480 a year.

The costs of reoperation are presented in table 6.5. The fees for reoperation on stomal disorders are referred to as a laparotomy. On average a hospital stay of 14 days is necessary.

Table 6.5 .

Costs of reoperation.

Fees visits outpatients" department

Preoperative investigations

Postoperative investigations

Fees reoperation

14 days stay in hospital
Dfl. $\quad 59.65$

270.45

200 .

802.25

$4,393.20$

Dfl. $5,725.55$

The incidence of ileostomy revision as reported above in chapter 2 is approximately $25 \%$. The Dutch stoma association, the Harry Bacon Club, estimated approximately the same percentage.

The incidence of reoperation in the continent ileostomy patients in this study was $40 \%$. Kock and Dozois ${ }^{40,34}$ had initially the same percentage of reoperation. With growing experience and better operation techniques fewer revisions were required ${ }^{6 *}$. The percentage of reoperations can be reduced to $20 \%$ or less ${ }^{34.90}$. In the present calculation a reoperation rate of $40 \%$ is assumed. As in this study most reoperations were done within one year after having obtained a continent ileostomy ${ }^{36}$.

Table 6.6. presents the cumulative costs of reoperation per patient for both ileostomy $(33 \%)$ and continent ileostomy $(66 \%)$ patients. This calculation was done by an iterative procedure.

Table 6.6.

Average costs of reoperation per patient.

$\begin{array}{ll}\text { Ileostomy } & \text { Dfl. } 1,890 .- \\ \text { Continent Ileostomy } & \text { Dfl. 3,780.- }\end{array}$


The use of wound dressings is assumed to be the same amount for the ileostomy patient as the continent ileostomy patient.

The survival rate of someone operated on for ulcerative colitis or polyposis coli with an ileostomy or continent ileostomy is considered to be the same as a healthy person, although no data concerning this issue are available. The average age of the continent ileostomy patient in this study was 32 years. The survival rate after this age is at least 40 years (for men 42 years, for women 49 years).

Considering these data, a comparison can be made between the costs of a conventional ileostomy and the costs of obtaining a continent ileostomy.

The expenses in the first year consist of expenses due to operation and/or reoperation and annual recurring expenses. Annual expenses of the conventional ileostomy patients are summarized in table 6.3. Annual expenses for the continent ileostomy patients consist of the costs of a new catheter used to empty the reservoir. Figure 6.14. presents these expenses in a chronological table. It can be calculated from the same figure that after approximately 5 years ileostomy patients incur the same expenses as patients obtaining a continent ileostomy.

In order to calculate how much money can be saved by conversion, a comparison between the costs of a continent ileostomy patient and a conventional ileostomy patient was made. Assuming a survival rate of 40 years, future costs are compared with current costs.

\section{CONVENTIONAL ILEOSTOMY}

cost of reoperation 1890

annual costs in Dfl.

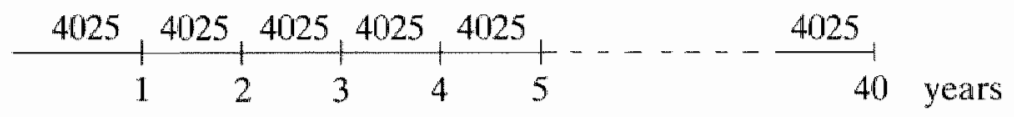

\section{CONTINENT ILEOSTOMY}

operation

costs

13859

cost of reoperation 3780

annual costs in Difl.

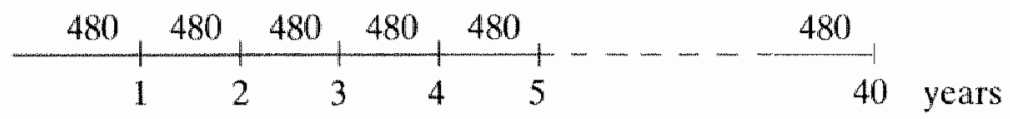

Figure 6.14.

The costs of a conventional ileostomy compared with the costs of a continent ileostomy. 
This must be done by the process of discounting ${ }^{154}$. When a discounting rate of $5 \%$ is chosen, approximately Dfl, 45,000 can be saved by converting a conventional ileostomy to a continent ileostomy. Although the discounting rate may vary, the continent ileostomy will be less expensive in the long term.

Apart from the improved quality of life, much money can be saved by converting a conventional ileostomy to a continent ileostomy. This financial aspect may be an additional motive for health insurance companies to support patients who are candidates for a continent ileostomy. 


\section{CHAPTER 7 \\ CLINICAL INVESTIGATIONS OF THE CONTINENT ILEOSTOMY}

\subsection{Introduction}

The continent ileostomy consists of a reservoir of distal ileum and an outlet of intussuscepted small bowel forming a nipple valve.

In the reservoir stagnation of intestinal contents occurs, which might favour bacterial growth, or might lead to an altered mucosal morphology due to mucosal irritation or might interfere with normal ileum absorption ${ }^{86}$. To investigate these aspects a number of continent illeostomy patients were selected at random and underwent a series of investigations.

7.2. Luminal content specimen was taken for qualitative and quantitative microbial analysis.

7.3. Mucosal morphology and histology was studied in biopsies from the mucosal reservoir.

7.4. Bile acid metabolism was studied by determining bile acid reabsorption from the reservoir and by analysing the composition of bile acids in the ileum effluent.

7.5. Pressure measurements of the nipple valve were done by manometric studies.

7.6. Ten patients were interviewed to get an impression of the quality of life of a continent ileostomy patient as compared to their previous life experiences.

\subsection{Bacteriological investigation}

\subsubsection{Introduction}

In the intra-abdominal ileal reservoir the intestinal contents are stored for several hours. The reservoir content, constituting a rich culture medium, the recurrent contamination by the non sterile emptying catheter, and the ideal temperature all favour bacterial growth.

Brandberg et al. ${ }^{\text {it }}$ found that bacterial ecology of the reservoir seemed to hold an intermediate position between ileostomy effluent and normal faeces. The purpose of this study was to evaluate the bacterial flora of ileal effluent from both conventional ileostomy and continent ileostomy by qualitative and quantitative bacterial cultures.

\subsubsection{Methods}

Illeum effluent was obtained from 7 patients with conventional ileostomies and 12 patients with continent ileostomies.

Ileostomies had been performed 6 weeks to 2 years prior to the time the specimens were obtained. Continent ileostomy had been carried out 6 months to 2.5 years prior to investigation. 
Ileostomy effluent was collected in fresh plastic ileostomy bags. Continent ileostomy effluent was collected in a sterile container by emptying the reservoir with a fresh catheter. These specimens were immediately taken to the microbiology department, where analysis was started at once.

Here $0.5 \mathrm{ml}$ ileum effluent was suspended in $50 \mathrm{ml}$ tryptose bouillon at $37^{\circ} \mathrm{C}$. One $\mathrm{ml}$ of the tryptose bouillon with ileum effluent suspension was thoroughly mixed with $9 \mathrm{ml}$ sterile tryptose bouillon and 10 fold tube dilutions were carried to $10^{-8}$. From each, $0.1 \mathrm{ml}$ was spread over the surfaces of the following media:

- kanamycin agar for anaerobes;

- anaerobic blood agar with NAT supplement (nalidixic acid + Tween 80 ) for grampositive anaerobes;

- blood agar and MacConkey agar for aerobic microorganisms;

- Sabouraud agar for yeasts;

- mannitol salt agar for Staphylococcus aureus.

Anaerobic incubation was carried out in a special cabinet (Forma Scientific,USA). The plates were incubated at $37^{\circ} \mathrm{C}$ for 48 hours. The number of specific microorganisms per $\mathrm{ml}$ of ileum effluent were expressed on a logarithmic scale from the mean colony counts on plates containing 10-1000 colonies.

For statistical analysis the t-test and the Mann-Whitney U-test were used.

\subsubsection{Results}

The distribution of microorganisms in the ileum effluent is presented in table 7.1. and 7.2. for both conventional and continent ileostomy patients. From the last ileostomy patient 3 consecutive samples were taken to control the reliability of findings of anaerobic and aerobic microorganisms in this study.

Figure 7.1. presents the distribution of anaerobic and aerobic microorganisms in both groups. The total number of microorganisms ( $\left.{ }^{10} \mathrm{log}\right)$ is significantly larger in the continent ileostomy group (mean 9.0,S.D. $=0.7$ ) compared with the ileostomy patients $($ mean 7.7, S.D. $=1.4)(p<0.01)$.

In 2 patients with continent ileostomies (nrs 11 and 12) no anaerobic microorganisms were found. This can be accounted for by the fact that they were receiving antimicrobial treatment (metronidazole and tetracycline) at the time of investigation. If these 2 patients in the continent ileostomy group are omitted, the remaining patients have a significantly larger number of anaerobic microorganisms in their ileum effluent (mean $8.6, S . D .=0.7$ ) compared with conventional ileostomy patients (mean 4.7, S.D. $=2.2$ ) $(\mathrm{p}<0.001)$. 
Table 7.1 .

Number of the different microorganisms (10/og) cultured in the effuent of the conventional leostomy patients.

\begin{tabular}{lccccccccc}
\hline Patient no & 1 & 2 & 3 & 4 & 5 & 6 & $7 \mathrm{a}$ & $7 \mathrm{~b}$ & $7 \mathrm{c}$ \\
\cline { 2 - 3 } & & & & & & & & & \\
Bacteroidesspp & - & 5.0 & - & 4.7 & 4.1 & 2.7 & 4.7 & 7.3 & 8.0 \\
Clostridium spp & 5.2 & - & 4.9 & - & - & - & - & - & - \\
Peptostreptocus spp & - & - & - & - & - & - & - & - & -
\end{tabular}

Aerobes:

$\begin{array}{lccccccccc}\text { E. coli } & 10.0 & 6.7 & 6.3 & 7.0 & 8.7 & 9.3 & 7.4 & 7.2 & 8.9 \\ \text { other coliforms } & 8.8 & 3.8 & - & 4.9 & - & 8.5 & - & 4.0 & - \\ \text { Pseudomonas aeruginosa } & - & - & - & - & - & - & - & - & - \\ \text { enterococci } & 9.4 & - & 6.3 & 7.3 & 4.5 & 8.0 & 7.0 & 6.8 & 8.3 \\ \text { Other streptococci } & - & 6.3 & 5.3 & - & 4.6 & - & - & - & - \\ \text { Staphylococcus aureus } & - & - & - & - & 4.0 & - & - & - & - \\ \text { other staphylococci } & - & - & - & - & - & - & - & - & -\end{array}$

Yeasts:

Candida albicans $\quad-5.0 \quad-\quad 3.3 \quad-\quad-\quad-4.0$

Torulopsis glabrata

Table 7.2.

Number of the different microorganisms $\left({ }^{10} \mathrm{log}\right)$ cultured in the effluent of the continent ileostomy patients.

\begin{tabular}{lllllllllllll}
\hline Patient no & 1 & 2 & 3 & 4 & 5 & 6 & 7 & 8 & 9 & 10 & 11 & 12 \\
\hline
\end{tabular}

Anaerobes:

Bacteroides spp

$\begin{array}{lllllllll}9.6 & 9.3 & 9.2 & 9.0 & 8.9 & 8.6 & 8.1 & 7.2 & 7.9\end{array}$

Clostridium spp

Peptostreptocus spp

Aerobes:

E. coli

other coliforms

Pseudomonas aeruginosa

enterococci

other streptococci

Staphylococcus aureus

other staphylococci

$$
\begin{array}{cccccccccccc}
4.8 & 8.2 & 7.8 & 7.5 & 4.2 & 5.3 & 7.0 & 9.0 & 6.7 & - & 5.4 & 9.4 \\
- & 8.0 & - & - & 4.0 & 5.0 & - & 8.3 & - & - & - & - \\
- & - & - & - & - & - & - & - & - & 7.3 & - & - \\
- & - & - & - & 3.0 & 4.0 & - & - & 6.2 & 9.2 & 8.2 & 10.2 \\
5.0 & - & - & - & 4.9 & - & - & 8.8 & - & - & 6.7 & - \\
- & - & - & - & - & - & - & - & - & - & - & - \\
4.2 & - & - & 7.4 & - & 3.7 & - & - & - & - & - & -
\end{array}
$$

Yeasts:

Candida albicans

Torulopsis glabrata

- $\quad 4.8-3.0 \quad-4.6-5.6-$

$-7.2-\quad-\quad-\quad 5.0$ 


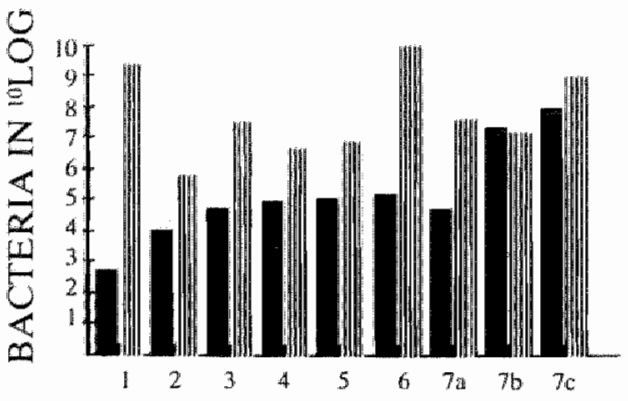

PATIENT NO

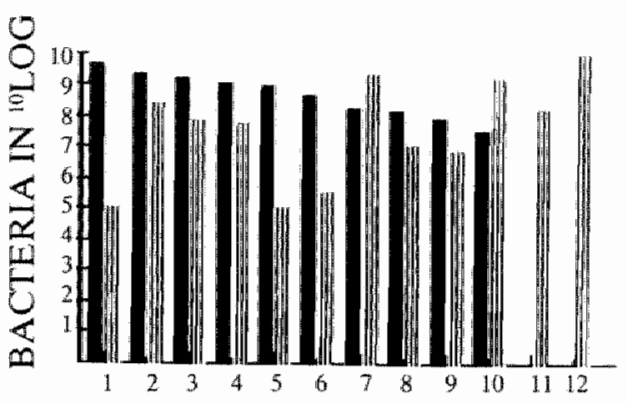

PATIENT NO

\section{IANAEROBIC MICROORGANISMS || AEROBIC MICROORGANISMS}

Figure 7.1.

Number of anaerobic and aerobic microorganisms (in ${ }^{10} \mathrm{log}$ ) in the effluent of the conventional ileostomy patients (left) and in the continent ileostomy patients (right).

\subsubsection{Discussion}

Ileum effluent collects in the reservoir of a continent ileostomy and catheter evacuation is performed at least 3 times a day. To a certain extent stasis, which might result in bacterial overgrowth, may occur ${ }^{86}$. This study reveals the numbers of microorganisms in ileum effluent of continent ileostomies to be ten times larger than for the conventional ileostomies and anaerobic microorganisms are present in significantly larger amounts. The numbers of microorganisms in the continent ileostomy effluent still are less than the numbers found in faeces ${ }^{15}$, which confirms the findings of others ${ }^{6.126}$. Composition of bacterial flora in ileostomy patients demonstrated a similarity to the findings of Finegold et al. ${ }^{46}$. The bacterial flora in the continent ileostomy patients is more comparable to colonic flora $\mathrm{a}^{46.97}$.

Absence of Staphylococcus aureus and the low number of other skin microorganisms (table 7.2.) might indicate the minor influence of contamination of the reservoir by inserting the catheter.

In conclusion, ileal effluent in continent ileostomy patients contains more microorganisms per millilitre than does the conventional ileostomy effluent and for the major part, it consists of anaerobic microorganisms. It is thus a more 'colon-like' flora. Bacterial contamination of the reservoir, due to inserting the catheter, seems to be of minor importance. 


\subsection{Histological examination}

\subsubsection{Introduction}

The reservoir of the continent ileostomy is constructed from a segment of distal ileum. In the reservoir intestinal contents are collected and stored. Assuming that altered luminal conditions might induce micro-anatomical alterations in the reservoir mucosa, Philipson ${ }^{126,127}$ and Nilsson ${ }^{114}$ investigated the mucosal morphology. Their most striking findings were reduction of the villus length and elongation of the crypts of the mucosa. The constant presence of noxious contents, such as bacterial toxins and metabolites, is probably responsible for these morphological changes ${ }^{86}$. Other histological changes, such as an inflammatory reaction in the lamina propria and submucosa, and an increased mitotic index were only seen in the early post-operative period. The present study was undertaken in order to analyse the development of mucosal alterations in the reservoir. Particular attention was paid to the functional differentiation of intestinal enterocytes and to the influence of time on the observed changes.

\subsubsection{Methods}

Biopsies from reservoir mucosa of 10 patients were taken 11-44 months after surgical construction of a continent ileostomy (average 23 months). These biopsies were compared to distal ileal mucosa specimens obtained from the proximal resection end of right-hemicolectomy specimens from patients with non-obstructing carcinomas of the colon ascendens (control group).

Tissue samples were fixed in $10 \%$ formalin, embedded in paraplast, sectioned at $4 \mu \mathrm{m}$ and stained. For light-microscopical and morphometrical evaluation haematoxylineosin staining was sufficient.

Morphometrical measurements were done by interactive computer assisted analysis using a MOP-videoplan (KONTRON). This instrument enables simultaneous measurement of villus length and crypt length to be carried out by indicating the dimensions of these structures on a graphic tablet. Villus length was measured from the top of the villus to its base on the surface of the ileum. Crypt length was measured from its deepest point in the lamina propria to its mouth on the surface of the ileum. Only sections showing villi and crypts along their entire length were used. On average 8 to 10 villi could be measured per section. The average crypt length and villus length as well as the villus/crypt ratio were calculated.

The number of villi per mm of mucosa was measured using a calibrated eyepiece. Further histochemical analysis was performed on serial sections. Mucine production and composition was studied by PAS-staining and HIDAB-staining ${ }^{140}$. Neuroendocrine cells were identified by hormone or amine content as determined using an indirect immunoperoxidase technique. Antibodies to Serotonin, Enteroglucagon, Somatostatin, Neurotensin and Pancreatic polypeptide were used. Specificity of these antibodies was described before $e^{94}$.

After deparaffinization, rehydration and blocking of endogenous peroxidase, the sections were incubated $(60 \mathrm{~min})$ with primary antibodies. After rinsing, the sections were incubated with goat anti-rabbit antibodies labelled with horseradish peroxidase 
Nordic). Peroxidase activity was visualized using diaminobenzidine (DAB) as chromogen. Control procedures included incubation of known positive tissue sections (positive control) and of test sections with pre-immuneserum (negative control). In the negative controls reactivity was never observed.

\subsubsection{Results}

Histological evaluation of reservoir biopsies revealed atrophy of villi in combination with crypt elongation, irregular spacing of crypts with varying diameter, branching crypts, hypercellularity of the lamina propria and some focal fibrosis (figure 7.2.). No signs of active inflammation were noticed. No evidence of dysplasia was seen in biopsies of the continent ileostomy patients. The villus/crypt ratio was quantitatively evaluated by morphometry. In the control group the villi showed an average length of $0.67 \mathrm{~mm}( \pm 0.07 \mathrm{~mm})$ and the crypts an average length of $0.13 \mathrm{~mm}( \pm 0.02 \mathrm{~mm}) \mathrm{In}$ the reservoir of the continent ileostomy patients the average villus length was $0.25 \mathrm{~mm}$ $( \pm 0.03 \mathrm{~mm})$ and the average crypt length $0.22 \mathrm{~mm}( \pm 0.03 \mathrm{~mm})$.

Table 7.3. shows the villus/crypt ratio the control group and in the continent ileostomy patients. In one reservoir biopsy reliable morphometry was impossible.

If the villus/crypt ratio is considered in relation to the time elapsed since the continent ileostomy operation, a decrease of this ratio can be seen as illustrated in figure 7.3. The number of villi per $\mathrm{mm}$ was significantly higher in the control group ( 7 to 8 ) as compared to the continent ileostomy group (6) ( $\mathrm{p}<=0.001$, using Cochran t-test).
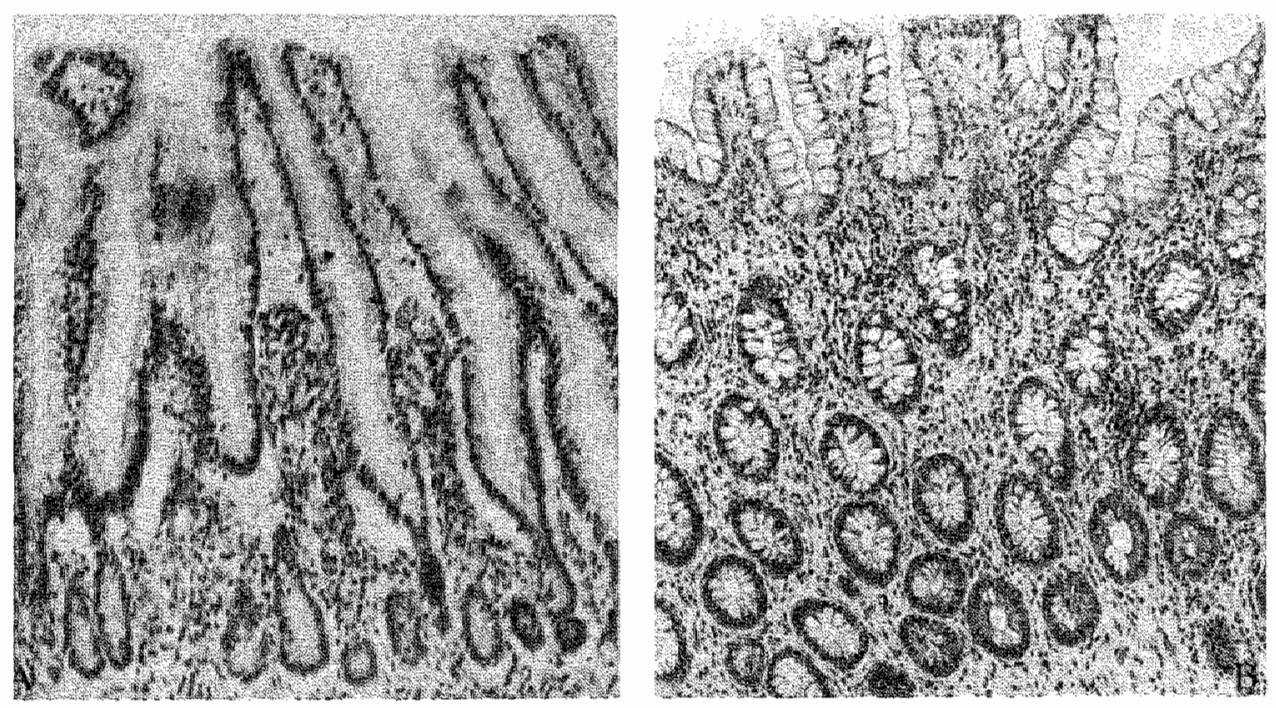

Figure 7.2.

Histology of distal ileum (low power H.E.-staining).

A. Control ileum mucosa.

B. Reservoir mucosa. Note hypercellularity of lamina propria, irregular spacing of elongated crypts and absence of villi. 
Table 7.3.

Villus/crypt ratio in normal mucosa and in reservoir mucosa.

\begin{tabular}{ccc} 
Patient & Control group & \multicolumn{2}{c}{ Continent ileost } \\
1 & 3.9 & 0.3 \\
2 & 4.3 & 0.6 \\
3 & 4.4 & 0.8 \\
4 & 4.4 & 1.0 \\
5 & 4.7 & 1.1 \\
6 & 4.8 & 1.3 \\
7 & 5.7 & 1.5 \\
8 & 6.2 & 2.1 \\
9 & 6.8 & 2.3 \\
10 & 7.0 &
\end{tabular}

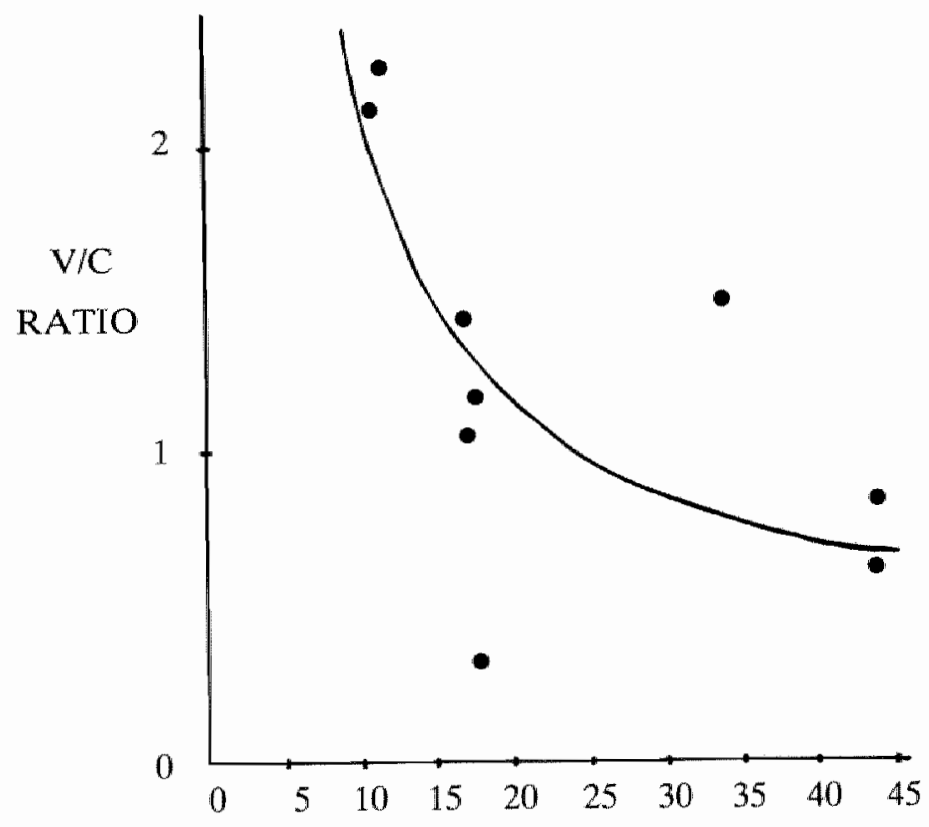

MONTHS POSTOPERATIVELY

Figure 7.3.

The villus/crypt ratio in relation to the time elapsed since the continent ileostomy operation. 


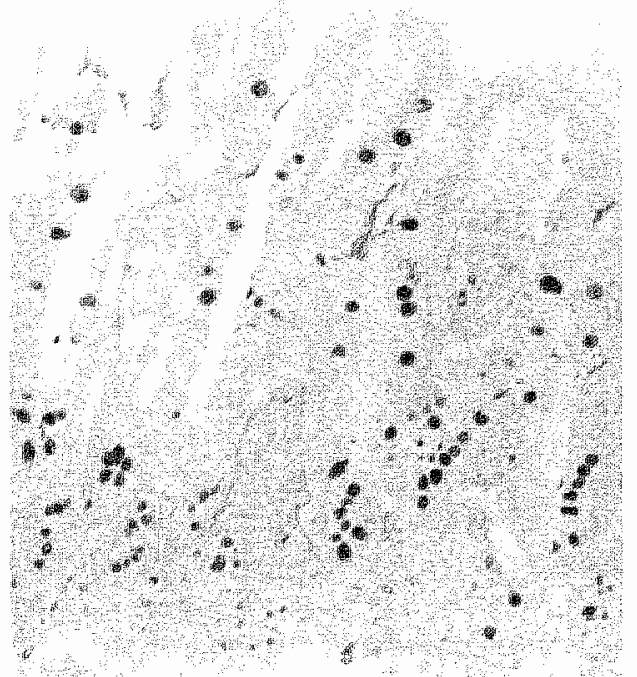

A

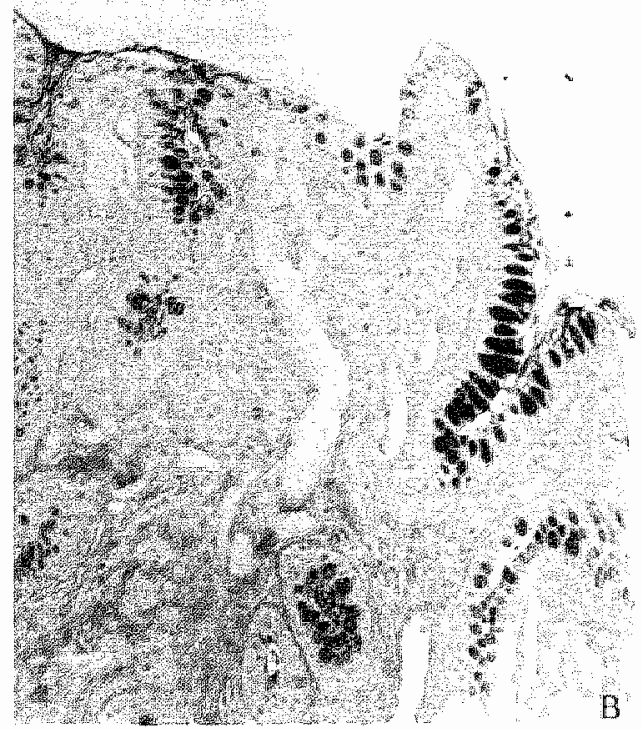

Figure 7.4.

HIDAB-mucine staining of intestinal ileum (low power).

A. Control ileum mucosa. Note regular distribution of goblet cells.

B. Reservoir mucosa. Note increased goblet cell density and irregular distribution.

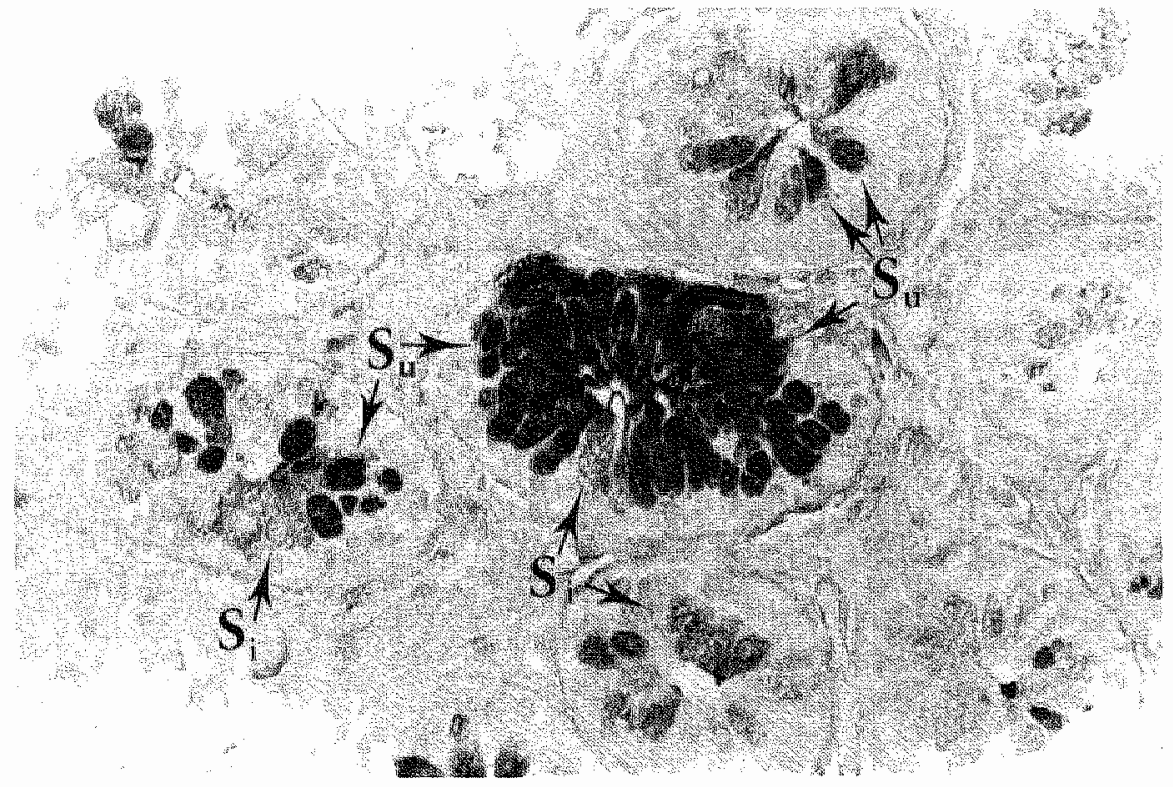

Figure 7.5 .

HIDAB-mucine staining (high power).

Crypts show goblet cell hyperplasia. Dark staining cells contain sulphomucine $\left(S_{v}\right)$, light staining cells contain sialomucine $\left(S_{i}\right)$. 
In PAS-stained sections goblet cell hyperplasia was frequently detected, increasing in severity towards the tip of the villus. With HIDAB-staining only sialomucine producing cells were found in the distal ileal mucosa of the control group. In the reservoir mucosa sulphomucine producing cells were found together with sialomucine producing cells (figure 7.4 and 7.5.). In the normal controls sulphomucine producing cells were only found in the colonic mucosa.

Serotonin immunoreactive cells were by far the most prevalent entero-endocrine cell types, in controls as well as in reservoir patients. Scattered immunoreactivity for Somatostatine and Glucagon was also noticed in both groups. Accurate quantitative comparison of these cells in reservoir mucosa versus the control group was impossible because of the relatively small number of cells in the mucosal biopsy specimens in the reservoir group.

\subsubsection{Discussion}

Construction of a continent ileostomy according to $\mathrm{Kock}^{86}$ results in a terminal ileal reservoir in which stasis of luminal contents occurs. As this condition conceivably resembles that in the colonic lumen alterations of the ileal mucosa in the reservoir may be expected. Indeed previous investigators have shown that in the early postoperative period the mucosa shows an inflammatory reaction and increased mitotic activity in the mucosal epithelium ${ }^{14,126,127}$. After longer intervals the only alteration which was found was a decreased villus/crypt ratio ${ }^{14}$. As part of a study on metabolic, microbiological and functional consequences of the Kock's continent ileastomy mucosal histology was investigated by morphometry and histochemical techniques. Architectural alterations, including fibrosis of the lamina propria, crypt irregularities (varying width, branching) and a decreased villus/crypt ratio were confirmed. The fibrosis in combination with the crypt irregularities suggest that early after construction of the reservoir an inflammatory reaction alters the mucosal architecture. This is in agreement with findings in early reservoir biopsies ${ }^{126,127}$. The combination of crypt elongation and partial villous atrophy is usually seen in conditions of increased epithelial turn-over. This contention is supported by the observations that the mitotic activity in the mucosal epithelium is increased. Nilsson's ${ }^{1 / 4}$ observation that with time the villus/crypt ratio again increases suggests that the epithelial turn-over rate tends to revert to normal after adaptation of the reservoir mucosa to the altered luminal environment.

One of the working hypotheses in this study was that reservoir mucosa might show colon-like functional characteristics. The goblet cell hyperplasia and the occurrence of sulphomucine production are in line with this hypothesis. The number and types of neuroendocrine cells, however, remained unaltered.

Therefore it can be concluded that early inflammatory reactions and increased epithelial turn-over result in a partially reversible architectural alteration of the reservoir mucosa, which also shows colon-like alterations of the goblet cell population. Dysplastic changes do not occur. 


\subsection{Bile acid investigation}

\subsubsection{Introduction}

Significant bile acid loss has been reported in patients with a continent ileostomy as was determined by measuring ileum effluent excretion of intravenously injected ${ }^{14} \mathrm{C}$-cholic acid. To understand the bile acid metabolism in the continent ileostomy patients, the metabolism in normal persons has to be considered. The bile acids cholic acid and chenodeoxycholic acid, are synthesized in the liver from cholesterol. These "primary bile acids" are conjugated with glycine or taurine prior to their active transport into the bile. The conjugated primary bile acids are stored in the gallbladder as long as the individual is fasting. During digestion bile acids are excreted into the lumen of the duodenum. Bile acids are transported together with the contents of the intestinal tract. In the gut the secondary bile acids are formed by microbial dehydroxylation, i.e. deoxycholic acid from cholic acid and lithocholic acid from chenodeoxycholic acid.

Conjugated bile acids are subject to an efficient enterohepatic circulation involving 3 pathways:

1. passive jejunal reabsorption;

2. active ileal reabsorption;

3. passive colonic reabsorption of secondary bile acids.

Bile acids are almost completely removed from the portal blood by hepatocyte extraction and then rapidly re-excreted into the bile. Accordingly, the quantity of bile acids present in the peripheral or portal blood normally represents a very small fraction of the total bile acid pool. In the fasting state nearly all bile acid pool is within the gallbladder and within the intestinal lumen during digestion.

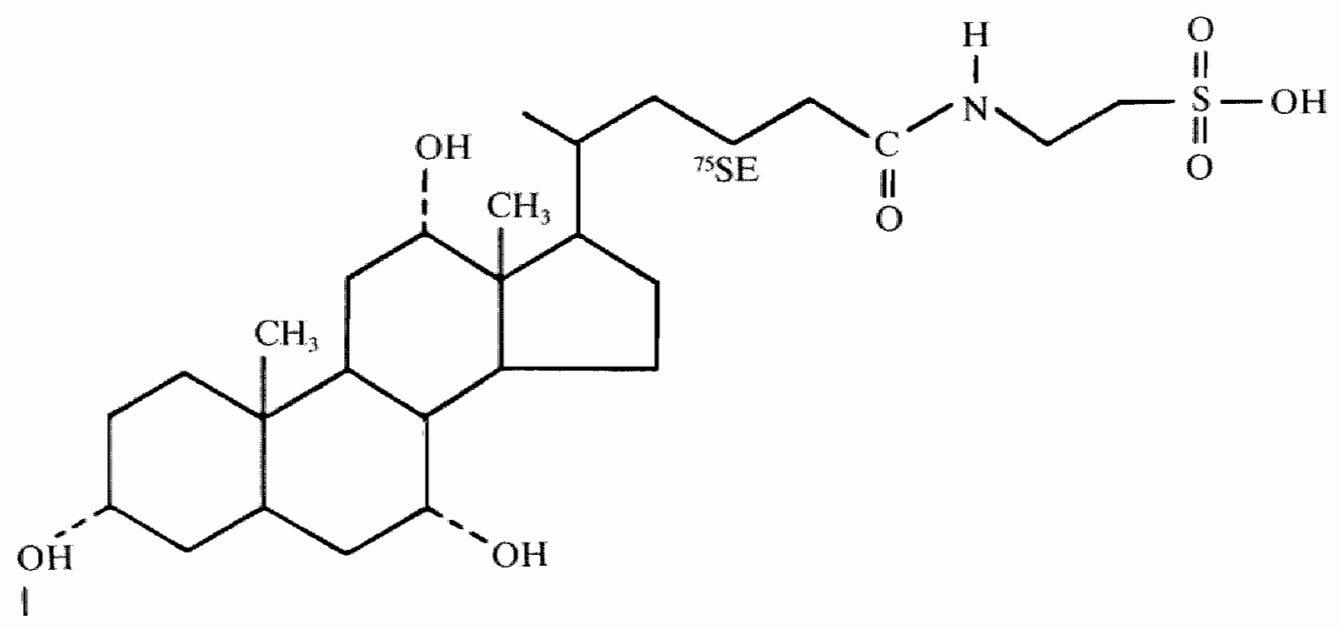

Figure 7.6.

Structure formula of Tauro-23 ${ }^{75}$ Selena-25 Homocholic Acid. 
In the present study bile acid metabolism was examined in 11 patients, $11-44$ months (average 23 months) after constructing of a continent ileostomy in order to obtain a better understanding of the physiological aspects of the reservoir, especially with respect to the reabsorptive capacity. None of the patients underwent a cholecystectomy.

The reabsorption of bile acids by the ileal reservoir was determined by injecting a radioactive ( $\gamma$-emitting) labelled bile acid conjugate, ${ }^{75}$ Selenium taurohomocholic acid (SeHCAT) into the reservoir. SeHCAT is a synthetic conjugated trihydroxy bile acid (see figure 7.6.), showing physiological behaviour identical to the naturally occurring bile acid conjugate taurocholic acid ${ }^{32,105}$. SeHCAT can be used to investigate terminal ileum function because no bacterial degradation neither in vivo nor in vitro of this $\gamma$-emitting cholic acid analogue occurs ${ }^{41}$.

The total quantities of bile acids excreted and the ratio of primary to secondary bile acids were determined in the ileum effluent in order to investigate the possible influence of bacterial flora on the bile acid metabolism.

\subsubsection{Methods}

\section{Determination of bile acid reabsorption from the reservoir.}

After the ileal reservoir had been emptied, one capsule containing approximately 370 $\mathrm{kBq}$ SeHCAT (supplied by Amersham, code SC.51P) dissolved in $2.5 \mathrm{ml}$ saline was injected directly into the reservoir. The radiation dose from $370 \mathrm{kBq}$ SeHCAT equals $14 \mu \mathrm{Gy}$ total body radiation in the first $24 \mathrm{hrs}$, amounting to a total dose of $100 \mu \mathrm{Gy}$ over the whole SeHCAT excretion period ${ }^{139}$. The exact quantity injected was determined by weighing the syringe before and after injection of SeHCAT, whereafter the administered dose of radioactivity could be calculated. The number of counts per minute (cpm) per ml were determined using a Berthold MAG 312 counter. Total activity remaining in the injection system was also counted and a correction was made. A standard meal was given and after 4 hours the reservoir was emptied and rinsed with water. Ileum effluent and rinsing fluids were weighed separately and were thereafter combined in a mixer. From this mixture $5 \mathrm{ml}$ were taken to determine the residual SeHCAT activity and total SeHCAT activity in ileum effluent was calculated. The residual fluid was subjected to analytical determination of bile acids. Serum values of bile acids and liver function tests were determined by routine procedures.

Blood samples were taken 10 minutes before and 10, 20,30, 60, 120, 240 minutes after injection of the SeHCAT into the reservoir to determine the SeHCAT activity in blood.

\section{Determination of total bile acids in serum and faeces.}

The sterognost- $3 \alpha^{\circledast}$ Flu method from Nyegaard \& Co, Oslo, was used for the determination of total bile acids in serum and faeces. The test is based on the method presented by Mashige et al. ${ }^{101}$ and Osuga et al. ${ }^{109}$. By $3 \alpha$-hydroxysteroid dehydrogenase ( $3 \alpha$-HSD) the $3 \alpha$-hydroxyl groups from steroids of the $\mathrm{C} 19, \mathrm{C} 21$, and $\mathrm{C} 24$ series, also including the taurine and glycine conjugates of the last group, are converted into the corresponding keto-groups, with generation of NADH from NAD+. The formed NADH by the enzyme diaphorase, reduces the fluorogen resazurin, whereby the fluorophore resorufin is formed and its fluorescence can be measured. 

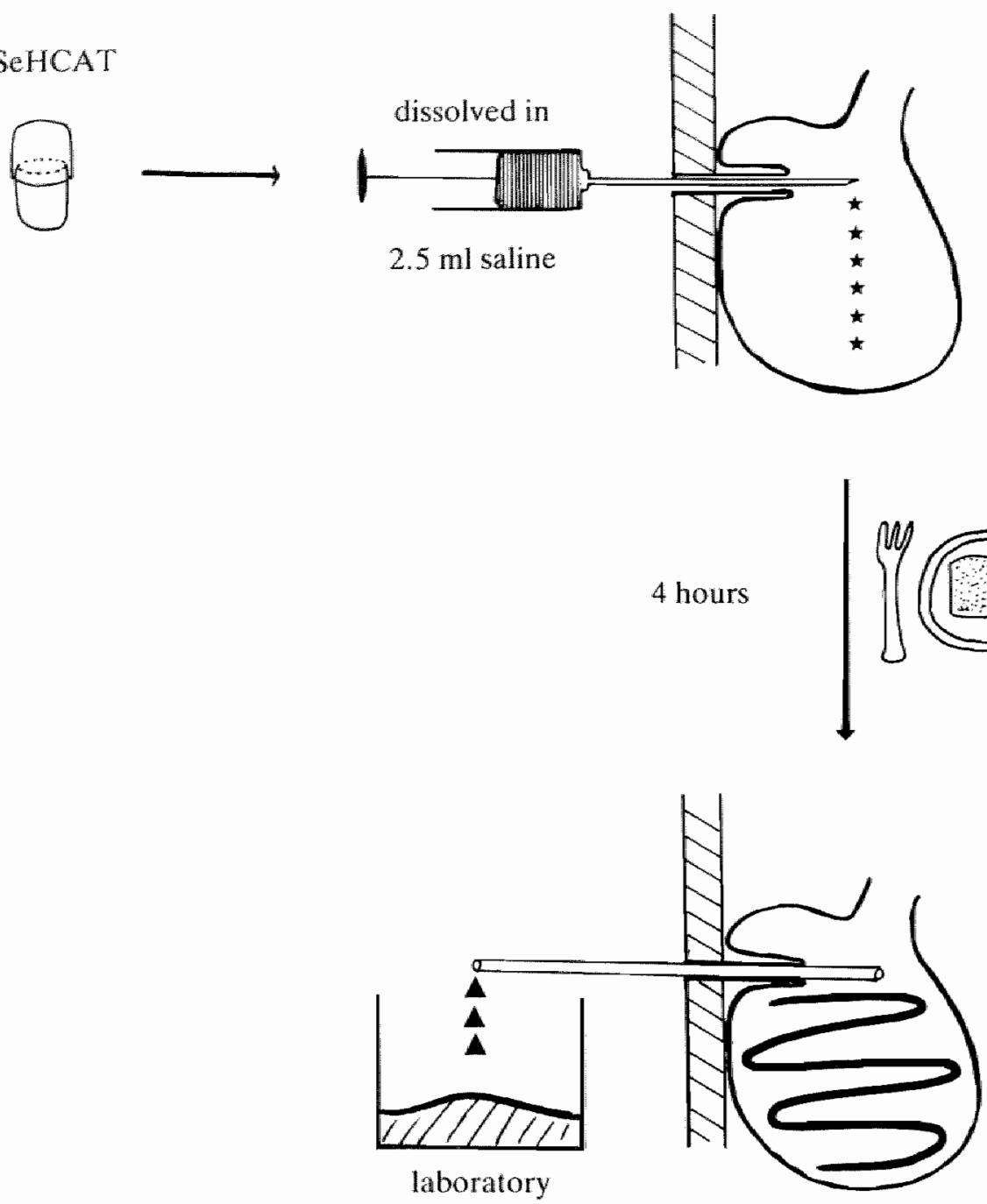

Figure 7.7.

Bile acid investigation in continent ileostomy patients. SeHCAT was dissolved in 2.5 $\mathrm{ml}$ saline and was instilled in the reservoir. A standard meal was given and after 4 hours the reservoir was emptied. The reservoir contents was brought to the laboratory for further investigation. 
Test principle:

$3 \alpha$-hydroxy bile acid $+\mathrm{NAD}^{+} \frac{\mathrm{pH} 9.5}{\mathrm{pH} 5.5}$ 3-keto bile acid $+\mathrm{NADH}+\mathrm{H}^{+}$

$\mathrm{NADH}+\mathrm{H}^{+}$resazurin $\longrightarrow \mathrm{NAD}^{+}+\mathrm{H}_{2} \mathrm{O}+$ resorufin.

Possible interfering enzyme activity in the serum and faeces specimens was inactivated by heating the specimen which was diluted in Tris- $\mathrm{HCl}$ buffer $(0.1 \mathrm{~mol} / \mathrm{h}, \mathrm{pH}=9.0)$ prior to analysis.

\section{Gas chromatographic analysis of bile acids in faeces and ileostomy effluent.}

The relative concentrations of the major bile acids, cholic acid, deoxycholic acid, chenodeoxycholic acid and lithocholic acid, both free and conjugated were determined using the method described by Verheesen and Brombacher ${ }^{153}$. Two aliquots of faeces or ileostomy effluent, containing $2-3 \mu \mathrm{mol}$ total bile acids each, were used for the determination of the relative amounts of total (aliquot $A$ ) and free (aliquot B) bile acid compositions. From these results the conjugated bile acid concentration was calculated.

Procedure:

The $\mathrm{pH}$ of both aliquots was brought to 5.2 with $\mathrm{NaOH}(2 \mathrm{M})$ or $\mathrm{HCl}(2 \mathrm{M})$ and $2.5 \mathrm{ml}$ of sodium acetate buffer $0.2 \mathrm{M}$ and pH 5.2 (Sorensen buffer) was subsequently added. Hydrolysis and extraction:

$\mathrm{N}$-cholyl glycine hydrolase, $0.2 \mathrm{ml}$ (Schwarz-Mann, $10.000 \mathrm{Units} / \mathrm{ml}$ ) was added to aliquot A. After mixing, hydrolysis was performed for 3 hours at $37^{\circ} \mathrm{C}$. Hereafter cold water was added to obtain a final volume of $10 \mathrm{ml}$.

Both aliquots were then extracted once with $20 \mathrm{ml}$ ethyl acetate for 10 minutes with shaking. Both tubes were centrifuged and from the organic layer an aliquot of $15 \mathrm{ml}$ was taken and evaporated to dryness in vacuo at $40^{\circ} \mathrm{C}$.

One $\mathrm{ml}$ of a bille acid standard solution, containing approximately $20 \mathrm{mg}$ of each of the bile acids was solved in $100 \mathrm{ml}$ chloroform, containing $5 \%$ methanol and was hereafter evaporated to dryness in a nitrogen stream. The standard residue was analyzed in the same way as the residues obtained from aliquots A and B.

Derivatisation:

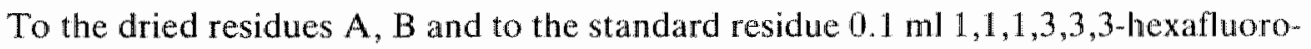
isopropanol (HFIP, Pierce chemical no 23950) was added and $0.2 \mathrm{ml}$ of trifluoroacetic anhydride (TFAA, Pierce chemical no 67363) The mixture was incubated at $37^{\circ} \mathrm{C}$ for one hour and afterwards dried in a nitrogen stream. The derivatives were then dissolved in $0.2 \mathrm{ml}$ of pure acetonitrile and gas chromatography was performed with $2 \mu \mathrm{l}$ sample of the obtained solutions.

The apparatus used was a Packard Becker type 428 gas chromatograph with F.I. detector, $180 \mathrm{~cm}$ glass column, internal diameter $0.2 \mathrm{~cm}$ packed with $3 \%$ OV -210 on Supelcoport 80/100 mesh.

Temperatures: oven $250^{\circ} \mathrm{C}$, detector $270^{\circ} \mathrm{C}$, injection port $270^{\circ} \mathrm{C}$. Carrier gas nitrogen $2.1 \mathrm{~kg} / \mathrm{cm}^{2}$ (30 p.s.i.). 


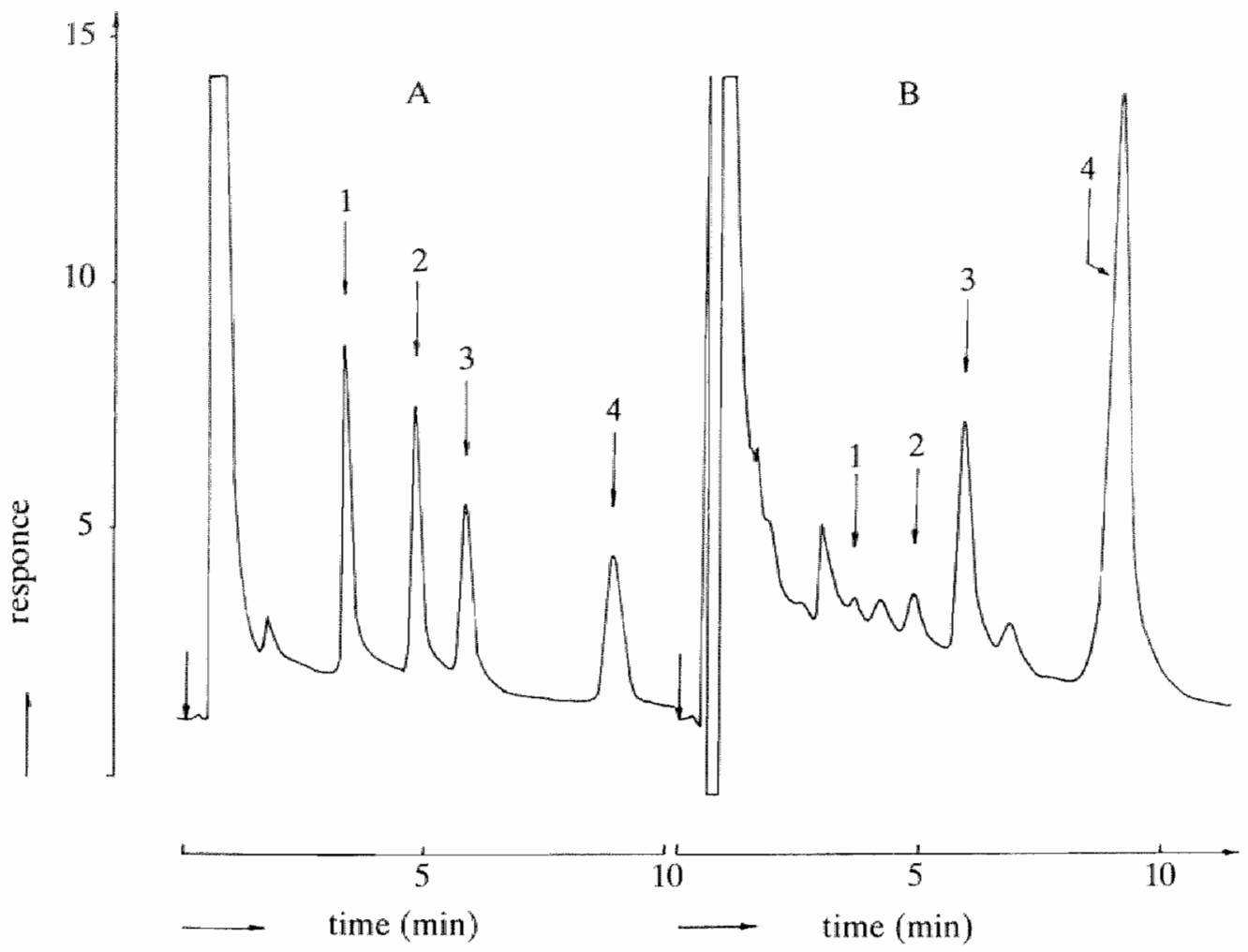

Figure 7.8.

Chromatography of an ileostomy effluent, containing lithocholic acid (peak 1), deoxycholic acid (peak 2), chenodeoxycholic acid (peak 3) and cholic acid (peak 4).

A: Total bile acids differentiated in the standard solution.

B: Total bile acids differentiated in ileostomy effluent in one of the patients.

Electrometer sensitivity $100 \times 32$. Recorder Kipp $10 \mathrm{mV}$ full scale.

Figure 7.8. presents the chromatography of the ileostomy effluent of one patient and the bile acid standard.

Calculation:

For each of the bile acids the detector response factor was calculated as follows:

RF(i) $(\mathrm{mm} / \mu \mathrm{mol})=\frac{\text { Peak height standard(i) }}{\text { Conc.standard (i) }}$

The relative concentration of the individual bile acids, $\mathrm{C}(1)=$ Lithocholic acid; $\mathrm{C}(2)=$ Deoxycholic acid; $\mathrm{C}(3)=$ chenodeoxycholic acid and $\mathrm{C}(4)=$ cholic acid, was calculated as follows:

C(i) $(\mu \mathrm{mol})=\frac{\text { peak height bile acid (i) in the sample }}{\mathrm{RF}(\mathrm{i})}$ 
$C(i)(\%)=\frac{C(i)}{C(1)+C(2)+C(3)+C(4)} \times 100$

\subsubsection{Results}

Serum values of protein, albumin, alkaline phosphatase (AF), gamma-glutamyl-transpeptidase ( $\gamma \mathrm{GT})$, amylase, lactic dehydrogenase (LDH), creatine kinase (CK), alanine aminotransferase (ALAT) and aspartate aminotransferase (ASAT), cholesterol and bile acids were within normal limits for all patients.

The percentage reabsorption of SeHCAT from the reservoir was calculated by subtracting the percentage of SeHCAT activity still present in the reservoir after 4 hours from the originally administered dose $(100 \%)$. Figure 7.9 . shows that the reabsorption varied from $75-97 \%$ (average $91 \%$, S.D. $=6 \%$ ).

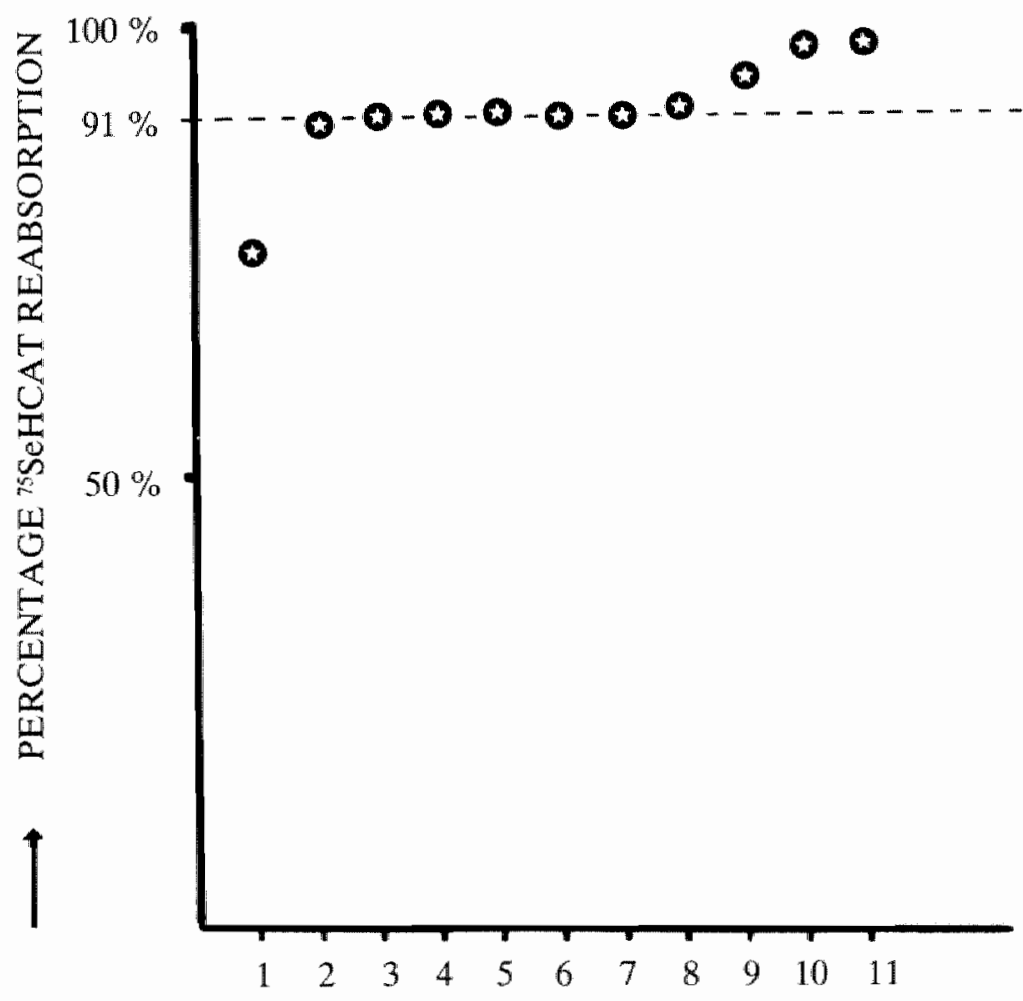

PATIENT NR

Figure 7.9.

The percentage SeHCAT reabsorption from the reservoir after 4 hours. 
The consecutive blood samples in these continent ileostomy patients showed that the amount of SeHCAT activity appearing in the blood varied considerably from patient to patient. Moreover, less than $1 \%$ of the activity injected into the reservoir appeared in the blood. Maximum activity was detected in the blood within 30 minutes after the SeHCAT was injected into the reservoir. The average total bile acid output in this study was $158 \mu \mathrm{mol}(22-479 \mu \mathrm{mol})$ in 4 hours as can be calculated from the data in table 7.4. If total bile acid loss during 24 hours is assumed to be six times the loss as measured during the 4 hour study period, the extrapolated bile acid loss will be $950 \mu \mathrm{mol}$ per 24 hours. This is within the normal range for bile acid loss in stools (reference range $400-1200 \mu \mathrm{mol} / 24$ hours).

The average weight of ileum effluent was $84 \mathrm{~g}$ per 4 hours, which implies a total loss per 24 hours of approximately $500 \mathrm{~g}$. The normal amount of ileum effluent loss per 24 hours is $500-700 \mathrm{ml}(1 \mathrm{ml}=1 \mathrm{~g})^{63.73 .73}$.

Table 7.4.

Results of the bile acid investigations.

\begin{tabular}{ccccccc}
\hline $\begin{array}{c}\text { Age Sex Diagnosis of } \\
\text { in } \\
\text { years }\end{array}$ & disease & $\begin{array}{c}\text { Months } \\
\text { post op. }\end{array}$ & $\begin{array}{c}\text { Serum } \\
\text { bile acid } \\
\text { in } \mu \text { mol/l/ }\end{array}$ & $\begin{array}{c}\text { Serum } \\
\text { in molesterol } \\
\text { mmol/l }\end{array}$ & $\begin{array}{c}\text { effluent } \\
\text { weight } \\
\text { ing }\end{array}$ & $\begin{array}{c}\text { total bile } \\
\text { acid excretion } \\
\text { in } \mu \text { mol/l } \\
\text { in } 4 \text { hours }\end{array}$ \\
\hline 19 & M Poliposis coli & 11 & & 3.3 & 115 & 479 \\
23 & M Ulcerative colitis & 16 & 4.8 & 4.3 & 23 & 82 \\
23 & M Poliposis coli & 17 & 4.0 & 3.9 & 138 & 86 \\
26 & M Poliposis coli & 44 & 4.8 & 3.7 & 64 & 22 \\
27 & F M.Crohn & 17 & 4.6 & 3.6 & 72 & 86 \\
30 & F Poliposis coli & 14 & 4.6 & 4.2 & 49 & 62 \\
33 & F Ulcerative colitis & 18 & 3.5 & 5.7 & 105 & 1.22 \\
33 & M Ulcerative colitis & 44 & 6.0 & 6.6 & 227 & 431 \\
37 & F Colon dysfunction & 12 & 5.0 & 5.1 & 40 & 45 \\
42 & F Poliposis coli & 33 & 6.0 & 4.3 & 42 & 67 \\
49 & F Poliposis coli & 44 & 5.4 & 3.2 & 46 & 252 \\
\hline
\end{tabular}

Figure 7.10. presents the proportion of the different bile acids excreted. Primary bile acids including cholic acid (average 64\%) and chenodeoxycholic acid (average 24\%) accounted for the major part, but secondary bile acids such as deoxycholic acid (average $89 \%$ ) and lithocholic acid (average $3 \%$ ) were also found.

Moreover, only free bile acids were present in the ileum effluent, indicating that all conjugated bile acids had been reabsorbed. 


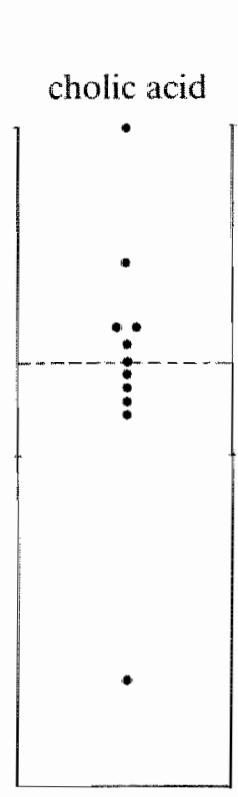

$64 \%$ chenodeoxy-

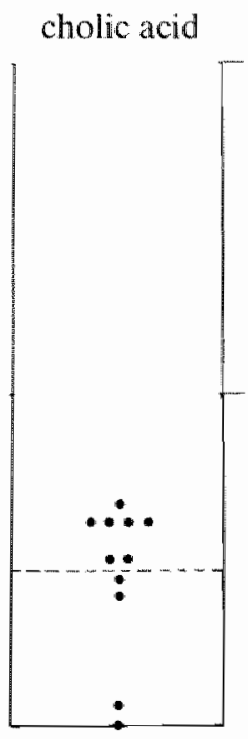

$24 \%$

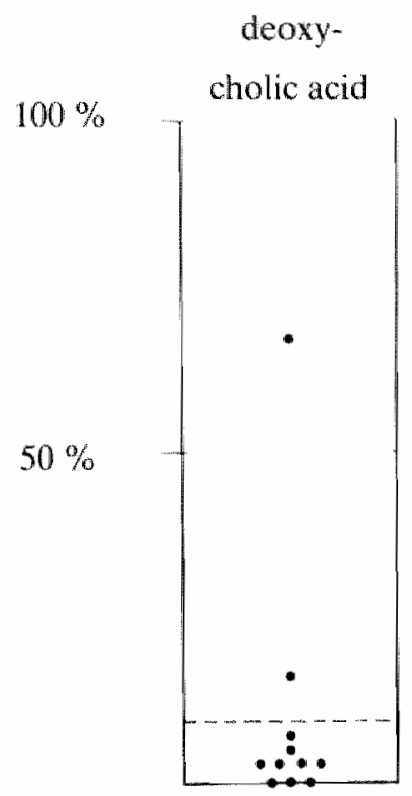

$9 \%$ litho-

cholic acid

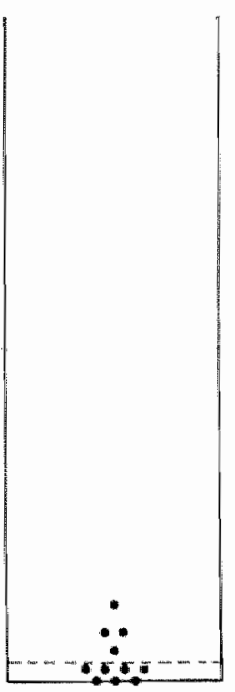

$3 \%$

Figure 7.10.

The distribution of primary bile acids (cholic acid and chenodeoxycholic acid) and secondary bile acids (deoxycholic acid and lithocholic acid) expressed as a percentage of the total excreted bile acid quantity.

\subsubsection{Discussion}

The distal ileum is the specific site where active reabsorption of vitamin $B_{12}$ and bile acids occurs. Normal values for the Schilling test have been recorded in patients with a continent ileostomy and it has been demonstrated that vitamin $B_{12}$ resorption needs the simultaneous administration of intrinsic factor ${ }^{47.112}$. Moreover, improved vitamin $B_{12}$ resorption has also been reported during simultaneous antibiotic treatment of these patients. This is an indication for the negative influence of bacterial overgrowth in the ileal pouch.

The reabsorption of bile acids in the continent ileostomy is still controversial. An increased output of ${ }^{14} \mathrm{C}$-labelled intravenously administered cholic acid, to some extent in conventional ileostomy and to a much larger extent in continent ileostomy and after resection of at least $50 \mathrm{~cm}$ of the ileum has been reported ${ }^{2.112}$. From a theoretical point of view two causes for malabsorption have been postulated: firstly, changes of the stagnated intestinal contents in the reservoir due to influence of its bacterial flora and secondly, structural mucosal changes in the reservoir that might interfere with the specific absorptive mechanism ${ }^{2}$ or the absence of sufficient ileal mucosa for active bile acid reabsorption. Loss of orally administered glycocholic acid occurs due to bacterial 
deconjugation and subsequent decarboxylation of glycine. Measurement of ${ }^{14} \mathrm{CO}_{2}$ in expired air is a method to estimate the extent of overgrowth of anaerobic bacteria in colonic disease.

However, Kay et al.$^{73}$ have found a normal bile acid output and have concluded that ileal bile acid reabsorption is not disturbed to a great extent in patients with a continent ileostomy, provided that enough functional ileum remains.

Absorption and excretion of ${ }^{75}$ Se-labelled conjugated homocholic acid (SeHCAT) can be studied without influence of bacterial flora on deconjugation or decarboxylation on the result of the investigation. Enterohepatic circulation studies with oral administration of SeHCAT or $23-{ }^{14} \mathrm{C}$-cholic acid provide identical results ${ }^{105}$.

Approximately $90 \%$ of a synthetic radioactive labelled bile acid (SeHCAT) instilled directly into the ileal reservoir is reabsorbed by the distal ileum of the reservoir itself. Although some reflux from the reservoir contents into the afferent loop may occur over a length of $15 \mathrm{~cm}^{16}$, most of the bile acids are reabsorbed from the reservoir. The detection of SeHCAT activity in the blood samples, which reached a maximum level within 30 minutes affirmed a rapid reabsorption of bile acids from the reservoir. In normal persons about $90 \%$ of the bile acids are reabsorbed from the small intestine ${ }^{6 t}$. The results of this study show that normal bile acid reabsorption occurs from the reservoir.

Excretion of bile acids in these patients appears to be within normal limits. Bile acid compositions are predominantly primary bile acids $(88 \%)$ and secondary bile acids for $12 \%$. Gadacz et al..$^{47}$ observed a total percentage of secondary bile acids in duodenal aspirates of continent ileostomy patients ranging from 0 to $11 \%$. A normal percentage of secondary bile acids as found in this study suggests that the influence of the bacterial flora of the small bowel (including the reservoir) on bile acid composition is of minor importance. If the bile acid excretion from the liver and gallbladder is not impaired, bile acid metabolism will be normal. This can be expected in continent ileostomy patients.

Because of the normal bile acid metabolism, one can presume that there is no enhanced risk of gallstone formation in continent ileostomy patients.

In conclusion, ileal bile acid reabsorption is not compromised in patients with a continent ileostomy and bile acids output appears to be within normal limits, consisting predominantly of primary bile acids. Despite histological changes of the mucosa (see chapter 7.3.) and an altered bacterial flora in the reservoir (see chapter 7.2.) bile acid metabolism appears to be normal in patients with a continent ileostomy. 


\subsection{Nipple pressure measurements}

\subsubsection{Introduction}

The continent ileostomy provides control over intestinal effluent in rest and during increased intra-abdominal pressure such as coughing or straining. Continence is achieved by 2 main factors ${ }^{8}$.

Firstly, a low pressure reservoir is created to collect intestinal effluent by folding the distal ileum in a special manner. Secondly, the nipple valve made of two leaves of the intussuscepted distal ileum controls the expulsion of the contents of the reservoir.

An iso-peristaltic or anti-peristaltic intestinal segment alone is incapable of attaining continence. Intussusception of a bowell segment of sufficient length is necessary ${ }^{84}$. Still, the exact mechanism of continence has not been clarified. It is assumed that a pressure zone in the nipple valve is responsible for controlling the reservoir contents. The nipple valve is usually closed and does not contain reservoir contents.

Pressure measurements were performed in 19 patients with a continent ileostomy using water-perfused side-open catheters to measure the tone of the nipple valve. This tone is best reflected by the yield pressure, i.e. the pressure required to force its walls apart ${ }^{110}$.

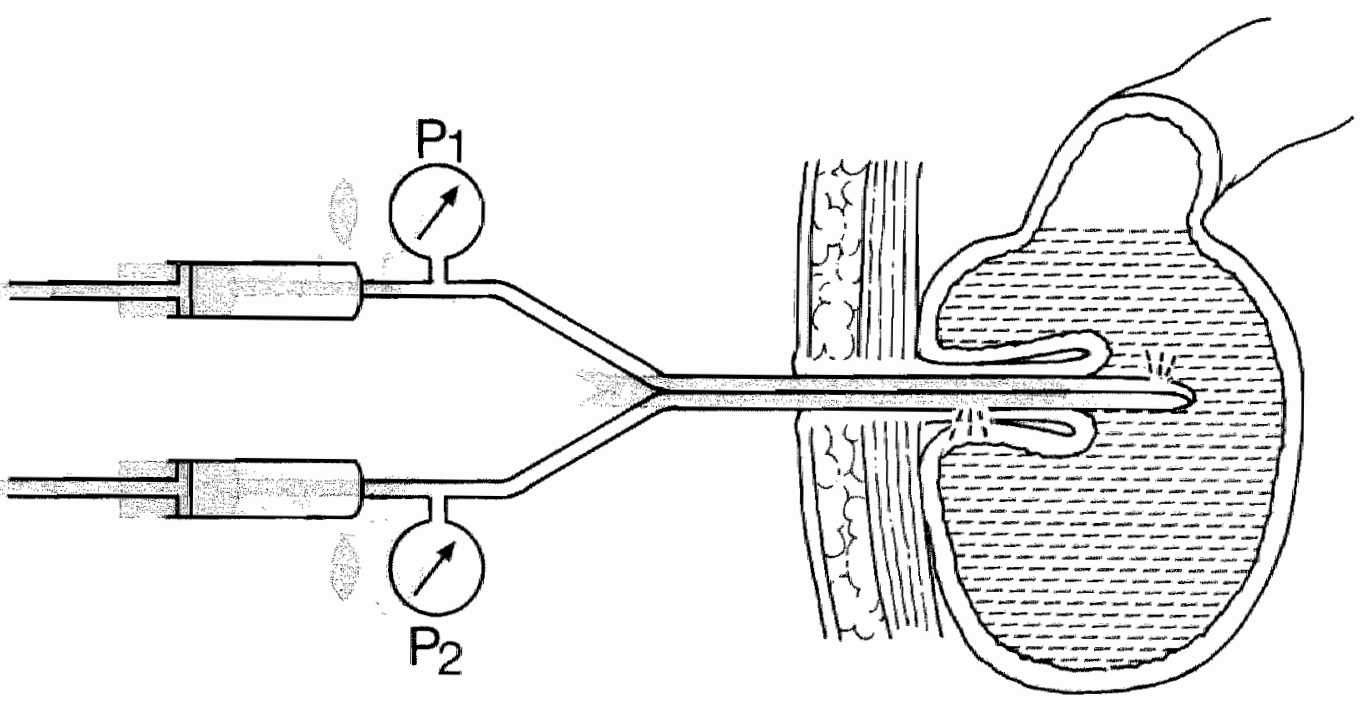

Figure 7.11.

Schematic drawing of the pressure measurements.

A double lumen catheter with two side-open apertures is withdrawn from the outlet of the reservoir. At the same time pressure recordings are simultaneously recorded representing the reservoir pressure $\left(P_{1}\right)$ and the nipple valve pressure $\left(\mathrm{P}_{2}\right)$. 


\subsubsection{Methods}

Seven men and twelve women were investigated with an average age of 30 years old (range 16-55 years). The measurements were done 2 to 44 months (average 14 months) after the continent ileostomy was constructed. The patient lay in a supine position. A rubber, double lumen catheter (diameter $4 \mathrm{~mm}$ ) with two side-open apertures (diameter $1.5 \mathrm{~mm}$ ), which are of the same size as each intraluminal diameter of the catheter, was introduced. The distance between the two apertures was $6 \mathrm{~cm}$. Care was taken that both apertures were in the reservoir at the onset of the measurements. While perfusing both lumina of the catheter at a rate of $10 \mathrm{ml}$ water $/ \mathrm{min}$., the catheter was withdrawn at the same speed as the paper of the recorder moved $(6 \mathrm{~cm} / \mathrm{min}$ ) (figure 7.11.). The pressure was measured with a Statham's pressure transducer model P 23 and continuously recorded on a Honeywell recorder. Most patients emptied their reservoir prior to recording. Pressure measurements were done firstly while the patient was lying comfortable and secondly while he was asked to perform the Vasalva manoeuvre to raise the intra-abdominal pressure.

\subsubsection{Results}

In all patients a zone with an increased pressure in the nipple valve was recorded compared to the reservoir pressure (ligure 7.12.). The average length of the segment with an increased pressure was $5 \mathrm{~cm}$ (range $4-6 \mathrm{~cm}$ ). This corresponded well with the length of the intussuscepted ileum measured by ileoscopy. The increased pressure zone
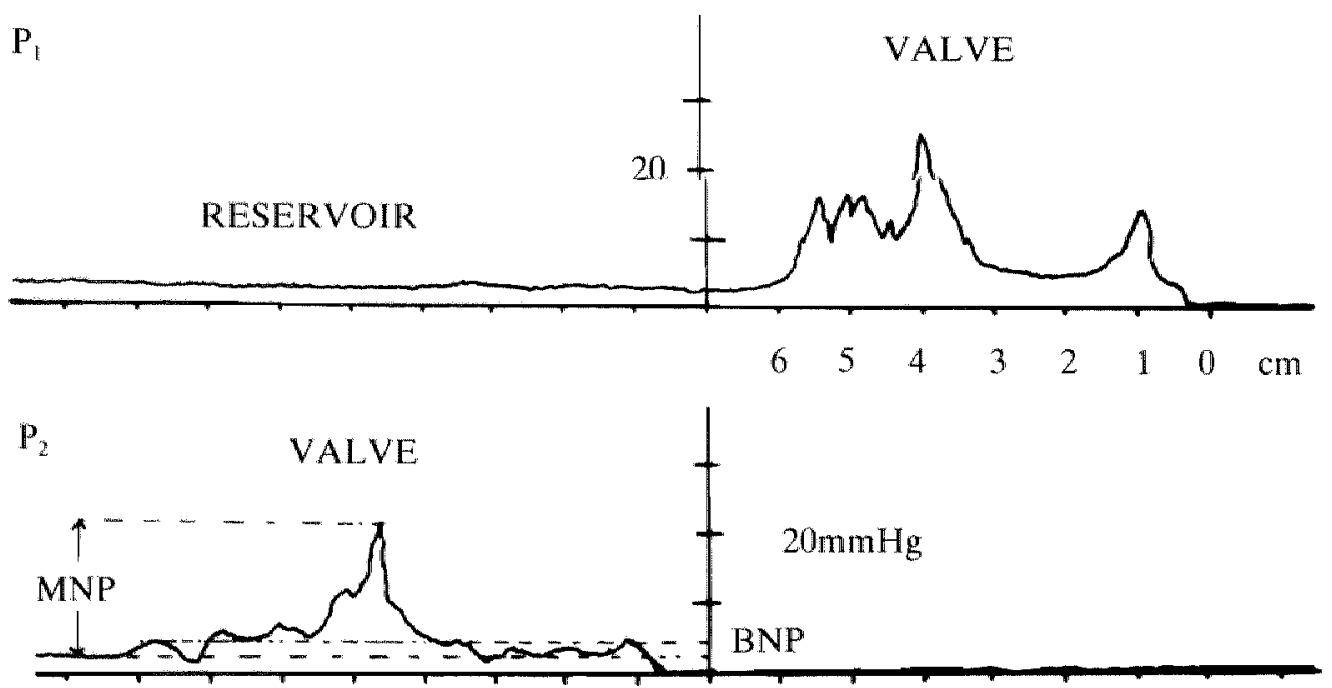

$\begin{array}{llllllll}6 & 5 & 4 & 2 & 1 & 0 & \mathrm{~cm}\end{array}$

Figure 7.12.

Recording of the reservoir pressure and the nipple valve pressure in a patient in rest. 

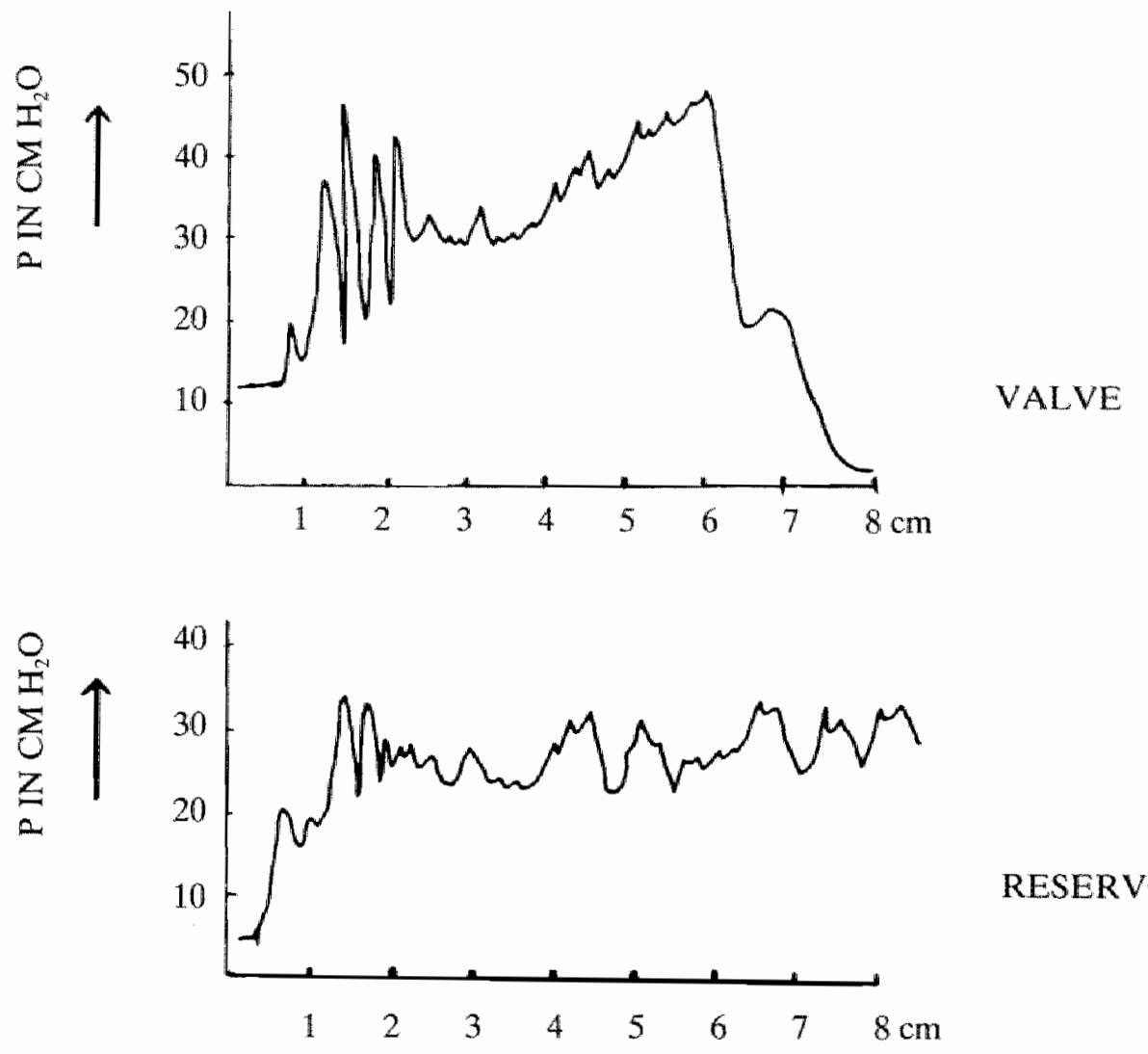

RESERVOIR

Figure 7.13.

Recording of the reservoir pressure and the nipple valve pressure in a patient during Vasalva manoeuvre.

at rest contains two elements of pressure elevation. A low pressure zone with continuous pressure elevation which is here called the "Basal Nipple Pressure" (BNP). On the BNP, spikes of higher pressure are superimposed. Pressure of the highest spike recorded is here called the "Maximum Nipple Pressure" (MNP). The MNP is thought to be caused by spontaneous contractile activity of the intussuscepted ileum ${ }^{10}$. The average pressure of the BNP is $5 \mathrm{~mm} \mathrm{Hg}$. The average pressure of the MNP is $21 \mathrm{~mm} \mathrm{Hg}$.

In 15 patients the reservoir pressure and the nipple pressure were recorded with increased intra-abdominal pressure (figure 7.13.).

This was not done in the first 4 patients examined. On average the nipple pressure was $5 \mathrm{~mm} \mathrm{Hg}$ higher than the pressure recorded in the reservoir at the same time.

The results are summarized in table 7.5 . 
Table 7.5.

Results of pressure measurements in 19 patients.

\begin{tabular}{ccccccc}
\hline $\begin{array}{c}\text { Patient } \\
\text { no }\end{array}$ & Sex & $\begin{array}{c}\text { Nipple } \\
\text { length } \\
\text { in cm }\end{array}$ & $\begin{array}{c}\text { BNP } \\
\text { in mm Hg }\end{array}$ & $\begin{array}{c}\text { MNP } \\
\text { in mm Hg }\end{array}$ & $\begin{array}{c}\mathrm{P}_{\text {nipplc }} \\
\mathrm{P}_{\text {reservir }} \\
\text { during vasalval }\end{array}$ & $\begin{array}{c}\text { Monts } \\
\text { post op. }\end{array}$ \\
\hline 1 & $\mathrm{~F}$ & 5 & 6 & 55 & 4 & 2 \\
2 & $\mathrm{~F}$ & 6 & 6 & 25 & 2 & 2 \\
3 & $\mathrm{~F}$ & 5 & 10 & 26 & 12 & 3 \\
4 & $\mathrm{~F}$ & 5 & 4 & 15 & not done & 3 \\
5 & $\mathrm{~F}$ & 4.5 & 2 & 16 & 5 & 4 \\
6 & $\mathrm{~F}$ & 5.5 & 2 & 16 & not done & 4 \\
7 & $\mathrm{M}$ & 5 & 4 & 12 & 2 & 5 \\
8 & $\mathrm{M}$ & 5 & 8 & 20 & not done & 10 \\
9 & $\mathrm{~F}$ & 5 & 4 & 18 & 4 & 10 \\
10 & $\mathrm{M}$ & 6 & 6 & 40 & 2 & 11 \\
11 & $\mathrm{~F}$ & 5 & 4 & 10 & 6 & 14 \\
12 & $\mathrm{M}$ & 4 & 4 & 38 & not done & 15 \\
13 & $\mathrm{M}$ & 4 & 4 & 6 & 5 & 16 \\
14 & $\mathrm{M}$ & 5.5 & 8 & 35 & 16 & 17 \\
15 & $\mathrm{~F}$ & 6 & 6 & 16 & 6 & 17 \\
16 & $\mathrm{~F}$ & 6 & 4 & 25 & 4 & 18 \\
17 & $\mathrm{~F}$ & 5 & 4 & 10 & 10 & 33 \\
18 & $\mathrm{M}$ & 4 & 10 & 14 & 4 & 44 \\
19 & $\mathrm{~F}$ & 4.5 & 4 & 16 & 10 & 44 \\
\hline
\end{tabular}

\subsubsection{Discussion}

In conventional ileostomy patients contractile activity was recorded along the prestomall ileum segment. No zone with increased pressure was measured at the outlet.

The nipple valve in the outlet of the continent ileostomy shows an increased intraluminal pressure as compared to the reservoir pressure. Such a rise in the basal pressure is probably caused by the intussusception of the intestine and spontaneous contractile activity in the nipple. The competence of the nipple valve depends on the highest pressure at any point in the nipple valve. At the same time contractile activity in the reservoir was absent. These findings support the theory that ileum effluent control in the continent ileostomy is achieved by a low pressure reservoir ${ }^{82}$, which can not overcome the higher pressure zone of the nipple valve".

If the intra-abdominal pressure is increased, as was achieved in this investigation by the Vasalva manoeuvre, the valve pressure increases also but remains higher than the reservoir pressure. As shown in table 7.5. this difference is roughly the same as the basal nipple pressure at rest. This can be accounted for by the valvular function of the nipple and its location in the reservoir itself. If the reservoir pressure rises, the nipple valve will be forced to close with the same increased pressure.

Spontaneous contractile activity in the nipple could not be distinguished during the Vasalva manoeuvre. 
It seems reasonable to assume that the length of the nipple valve with a high pressure zone is also important. The longer the nipple valve, the more likely it is that the pressure is higher at any point in the nipple valve than the pressure in the reservoir. A length of $5 \mathrm{~cm}$ seems to be sufficient ${ }^{33}$.

There was no correlation between nipple pressure values and the patients' sex or age, nor was there any correlation with the time elapsed after the continent ileostomy operation. In one patient the pressure measurements were repeated after one year. The same pressure profile was found although the value of the BNP and the MNP differed from the previous measurements. Two patients who complained of leakage from the continent ileostomy were operated. A longitudinal segment of the nipple valve was removed in such a way that the valve was narrowed (see figure 6.13.). This was done because no signs of dessusception were found at operation. Before this procedure no clear nipple valve pressure pattern was obtained with manometric measurements. Post-operatively, when the patients were continent, a normal pattern was recorded (patients nos 2 and 5 ). Although from these two experiences no conclusions could be drawn, they might indicate that the nipple valve pressure measurements may be a useful diagnostic tool. No pressure recordings were done in patients with a slipped valve. It may be assumed that in such a case the length of the pressure zone will be decreased.

It can be concluded that in all continent patients with a Kock's ileostomy a zone with increased pressure in the nipple valve can be demonstrated. Both in rest as well as during increased intra-abdominal pressure, the nipple valve pressure remains higher than the reservoir pressure. These phenomena seem to be important for controlling the expulsion of the reservoir contents. 


\subsection{Psychosocial aspects}

\subsubsection{Introduction}

One of the main reasons for Kock ${ }^{82.85}$ to elaborate the continent ileostomy was the almost continuous flow of intestinal discharge through the ileostomy, which necessitates the permanent use of external ileostomy appliances. Having a stoma and wearing an outside bag may create psychological, social and sexual problems in patients. McLoad et al. ${ }^{103}$ found from a questionnaire by 322 ileostomates that $72 \%$ stated that they led "normal" lives. However, skin irritations, unpleasant noises and odour were problems encountered in more than half of the patients. A study by Rolstad et al. ${ }^{131}$ revealed that $46 \%$ of long-term ileostomy patients found that the presence of the stoma made sexual intercourse psychologically difficult. In $72 \%$ this was related to their appliances.

Absence of external appliances and control of ileum discharge improved the ileostomy patients' quality of life $\mathrm{e}^{51,81,102,113}$. After the continent ileostomy operation other problems might occur. To get an impression of the psychological aspects of this operation, 10 patients were interviewed after conversion to a continent ileostomy. The interviews were taken at the "De Wever" Hospital, where all patients obtained their continent ileostomy, by a former stoma nurse who was instructed by an expert psychologist ${ }^{22}$. The following 13 items were asked and discussed with patients in the interviews. The answers are reported here per item.

\subsubsection{Report of interviews}

\section{Personal and social data}

Five men and five women were interviewed 11 to 44 months (average 20 months) after having obtained a continent ileostomy. Two patients obtained a continent ileostomy 1 year and 2 years respectively after a troublesome period with an ileorectal anastomosis. Eight patients had had an ileostomy for an average of 6 years ( $1-12$ years) prior to conversion to continent ileostomy. Their average age was 30 years (19-44 years) at the time of interview. Four patients were married and two had a permanent relationship. Eight patients had an outdoor job and two were housewives.

\section{The meaning of having a stoma}

At the time when the patients with an ulcerative colitis ( 5 patients) needed an ileostomy they were severely ill. They had no choice. It was merely a choice between life and death. Afterwards they felt better physically although an ileostomy was a disabling remnant of their disease. This group of patients had much trouble accepting it.

Patients with polyposis coli ( 4 patients) had a great risk of obtaining large bowel cancer. Their decision to obtain a stoma was taken while they were not ill. Usually they had relatives with an ileostomy, which gave them a better insight into living with an ileostomy and gave them less difficulty to accept it. 
The only patient with a colon dysfunction, who had had an ileorectal anastomosis, had so much trouble with the disease, that this patient ultimately decided on obtaining an ileostomy.

For all patients it was a shock, when they heard that a stoma was inevitable.

\section{Influence of the conventional stoma on body image, self-respect, social activities, relations with others (partner), sexual activities}

Eight patients reported an altered body image. Those were the patients, who previously had a conventional ileostomy. The wearing of a bag and the risk of leakage bothered them most. There was a considerable loss of self-respect. One patient even avoided to look in the mirror to watch her abdomen. Others felt ashamed of their bodies. Life had changed. Loose clothes had to be worn to camouflage the stoma and appliances. Six patients ceased sports. Visits to friends, theatre or cinema were reduced and only done after careful preparation. Two did not even eat for a whole day to reduce stoma outflow when they went out. Only if optimum sanitary equipment was present, five would go on holiday.

Their relations with others and especially the other sex was restricted and hindered by the ileostomy. It was difficult to tell to someone that they had a stoma.

The ileostomy patient's spouse or partner in most cases accepted the new situation if they already had a good relationship before. One patient divorced during the time he had a conventional ileostomy. Although he admitted that the stoma was not the reason for the divorce he said that it had contributed to it. In this group of patients no impotence or physical sexual disorder was present. The stoma was more of a problem to the ileostomy patient himself/herself than to his/her partner during sexual intercourse. The risk of leakage was their main fear. The wearing of a "bag" was experienced as something that should not be there.

\section{Aspects of the continent ileostomy that solve the problems experienced with the conventional ileostomy}

By not wearing stoma appliances the patients had a greater feeling of freedom. They could wear tighter cloths and beachwear again, without restrictions. By controlling the ileostomy discharge most patients felt more "normal". One person even felt the urge of defecation when the reservoir needed to be emptied. Having no risk of leakage encouraged them to attempt more activities. They took up sports (e.g. fitness, swimming) again, went on holiday, although good sanitary equipment temained an important factor.

They needed less equipment to take care of the continent ileostomy. They felt more self-confident and had more courage to start relationships. As far as could be compared the sexual activity was experienced better than with a conventional ileostomy.

One patient had no intercourse during the time she had a conventional ileostomy. This was restored after conversion to a continent ileostomy. Only one patient experienced the continent ileostomy as not being better than the conventional ileostomy. Bulky intestinal discharge hindered the patient to empty the reservoir. Liquid food had to be eaten most of the time and laxatives were to be used. 


\section{Disadwantages of the continent ileostomy}

As a disadvantage of the continent ileostomy it was mentioned that not all kind of food can be eaten. Fibrous food such as asparagus, oranges, pineapples and other food such as mushrooms, peas, beans and peanuts may obstruct the catheter. Onions and cabbage may lead to excessive intestinal gas formation. Although similar food problems are also found in patients with a conventional ileostomy, good chewing is absolutely necessary for continent ileostomy patients even more than for a conventional ileostomy. Another problem, although of minor importance is the fluid discharge of the mucosa of the continent ileostomy outlet. Usually regular renewal of the gauze dressing will be sufficient. The discharge might be more during exertions or in summertime and less in rest or in wintertime. Obviously the continent ileostomy remains a stoma, which is worse than having no stoma at all.

\section{The partner's attitude towards the continent ileostomy in comparison to the conven- tional ileostomy}

The partner's attitude was not much altered after the patient had obtained a continent ileostomy. One partner helped the illeostomist with stoma care before and after obtaining a continent ileostomy.

For the young patients the conversion to the continent ileostomy had a positive effect with regard to seeking a partner.

\section{Information on the continent ileostomy operation}

Two patients were given information on the continent ileostomy in our hospital. In 4 patients their physicians informed them about the possibility of having a continent ileostomy. Four patients heard from friends or read in a magazine for stoma patients about the operation and got in touch with our hospital. They all obtained information about the operation and possible complications in detail. Seven patients were satisfied with the information given.

\section{Information concerning the continent illeostomy operation not given pre-operative- ly, which turned out to be important postoperatively}

While informing the potential continent ileostomist it cannot be stressed enough that complications may occur and these may need reoperation before continence is achieved. It is also important to point out to them that dietary restrictions remain with a continent ileostomy. Food must be chewed better than before.

\section{Experience of the operation and the first period afterwards}

Despite enthusiastic stories of other patients, the continent ileostomy operation remains a heavy abdominal operation, which was often underestimated. The two-stage procedure, first the continent ileostomy operation and second closing the loop ileostomy, was disappointing for two patients. Some abdominal cramps were noticed in the first period after operation, most likely due to stretching of the reservoir. Nevertheless, they all found it worthwhile, considering the final result. 


\section{Attitude of the previously medical attendant towards the continent illeostony}

The surgeons of 3 patients condemned the continent ileostomy. Even if good results were achieved, they still rejected the operation afterwards. This negative advice did not alter the patients' decision to obtain a continent illeostomy. The other patients were informed by their surgeons about the continent ileostomy operation and they were sent to our hospital for further information.

\section{Advice for aspirant continent ileostomates}

The people who underwent the operation felt that it was important to be informed in detail about the operation. It has to be realized that it is a heavy abdominal operation. Complications may occur and re-operations may be required to obtain or maintain continence.

It is also important to discuss with the patients what life will be like with a continent ileostomy. This is best done, of course, by arranging a personal contact with persons who already have obtained a continent ileostomy. One has to speak with people in favour of it and against it.

Final advice: make your own decision !

\section{What do physicians have to know about the continent ileostomy}

For almost all patients it was disappointing that so Jittle physicians knew about the existence of a continent ileostomy. Two patients had difficulties to pass a medical examination for a job, because of the ignorance of these physicians concerning the continent ileostomy.

\section{What do people in general have to know}

Most patients found it important that other people knew something about stomas. This subject is often considered to be a taboo. More attention might make this subject more understandable and easier to discuss.

\subsubsection{Discussion}

In $1975 \mathrm{King}^{81}$ reported a dramatic improvement in life style and a high level of patient satisfaction with a continent ileostomy. Nilsson et al. ${ }^{113}$ found in a retrospective study of 48 patients an improved quality of sexual life in about $85 \%$ of both men and women after conversion to a continent ileostomy.

Other studies of Gerber ${ }^{51}$ and McLoad ${ }^{102}$ confirm these data. The overall patients satisfaction with the Kock pouch was $98.7 \%$ and $97 \%$ respectively, despite revisional surgery and complications such as pouchitis. Improvement was reported in social activities (problems with leakage, odour, skin irritations), athletic endeavours (jogging, cycling) and sexual relations. They wore street and beachwear with greater ease.

In this study interviews were taken after patients had obtained a continent ileostomy. It would be better to interview patients before and after they were operated. A bias may be present as the interviews were taken in the same hospital where the patients had been treated previously. Therefore this study can only give an impression of the 
patient's experience of the conversion to a continent ileostomy.

It can be concluded that the continent ileostomy improves the quality of life of patients with a permanent ileostomy. The feeling of freedom, because of not wearing external appliances and to feel more "normal" because of the ability to control the intestinal discharge is the greatest benefit. An altered body image and loss of self-respect with a conventional ileostomy might also contribute to the decision to obtain a continent ileostomy.

Some disadvantages of the continent ileostomy as dietary restrictions and the necessity of chewing the food good should be mentioned. Since most patients eligible for this operation are young, dietary problems that will last a patient's life-time, should not be underestimated and should be discussed thoroughly.

The fluid loss from the mucosa seems to be of minor importance, but can bother the patient. It must be realized that the continent ileostomy operation is a heavy abdominal procedure and complications may occur.

By far the greater number of patients found the operation worthwhile and would undergo it again if they had to decide again. Physicians should be informed more about the continent ileostomy so that patients who are candidates for this operation can be informed. If a patient is interested, he must be fully informed.

Discussions with patients who already have had a continent ileostomy are important before the patient decides in favour of a continent ileostomy.

In view of the results achieved it would be advisable to give this operation into consideration to all patients who might be potential candidates. 


\section{SUMMARY AND CONCLUSIONS}

The continent ileostomy, introduced by Nils Kock in 1969, consists of an intra-abdominal reservoir and an outlet constructed from the distal part of the ileum. The reservoir can be emptied regularly by using a catheter. Control of ileum effluent and absence of external appliances improves the quality of life for a person with an ileostomy.

In 1982 the procedure was introduced in the "De Wever" Hospital in Heerlen. In this study an account is given of the first 30 patients who underwent this operation in the period from January 1982 until October 1985.

In chapter 2 a literature survey of conventional ileostomy is given. After a long trial and error period the Brooke ileostomy has turned out to be the golden standard. The indications for an ileostomy are discussed and major complications such as metabolic and mechanical complications are mentioned. Moreover, separate attention is focussed on the psychosocial complications which are too often underestimated in ileostomy patients, while such complications in fact determine the quality of life to a high degree.

In chapter 3 some alternatives to the ileostomy valve constructions are described. The sphincter-saving operations such as ileorectal anastomosis and ileoanal anastomosis are discussed.

In chapter 4 a description of the continent ileostomy is given.

Theoretical considerations of a low pressure reservoir constructed from distal ileum are outlined. Several outlets of the reservoir were tried before the 'nipple' valve, constructed from an intussuscepted part of the small bowel, proved to control small bowel effluent adequately. As dessusception of the nipple valve was the major complication of the continent ileostomy procedure, many techniques were developed to maintain intussusception of the small bowel.

The biological consequences of this procedure, i.e. changes in bacteriological flora, mucosal morphology and absorption, were reviewed. Indications and contra-indications for the procedure were discussed . Continence was achieved in almost $95 \%$ of the patients, although a high rate of reoperations was needed to achieve this high percentage. A better quality of life, obtained by controlling ileum effluent and absence of having to wear external appliances, has encouraged patients to undergo this operation.

In chapter 5 an epidemiological survey on patients who obtained a continent ileostomy in the 5 year period from 1979 to 1983 is presented. It can be estimated that approximately 4,000 persons in the Netherlands have an ileostomy and that approximately 400 of them are eligible for a continent ileostomy.

In chapter 6 the first 30 patients ( 11 men and 19 women) who obtained a continent ileostomy at the "De Wever Hospital" are evaluated. The indications are mentioned. The currently used operative techniques and postoperative care are described in detail. In 13 out of the 30 patients reoperations were necessary. From this group of 13 one patient died because of metastasis of a rectum carcinoma and radiation enteritis, while in 2 patients the continent ileostomy was removed. The other 27 patients remain continent. 
A cost analysis comparing the expenses of the conventional ileostomy and the continent ileostomy was made. In conclusion, approximately Dfl. 45,000 can be saved by converting a conventional ileostomy to a continent ileostomy.

In chapter 7 several aspects of continent ileostomy are highlighted.

The biological consequences of an ileal reservoir with regard to bacterial flora, mucosal histology and bile acid metabolism were studied. Pressure characteristics of the nipple valve and the reservoir were measured. Ten patients were interviewed on the effect of a continent ileostomy on their lives.

Qualitative and quantitative bacterial cultures showed that the reservoir effluent of the continent ileostomy contained a number of microorganisms per millilitre which was 10 times that of conventional ileostomy effluent. In the continent ileostomy patients anaerobic microorganisms were cultured in a significantly large number. This indicates a more 'colon-like' flora.

Morphometrical investigations of the reservoir mucosa showed an altered villus/crypt ratio as compared with normal ileal mucosa. The villi became shorter and clubshaped, while the crypts elongate. Reactive alterations were seen by light microscopy. In addition to the appearance of goblet cell hyperplasia and sulphomucine producing cells in the reservoir mucosa, these findings indicated a 'colon-like' change of the mucosa. The endocrine cell population proved not to be altered as compared to normal ileal mucosa. Precancerous changes were not found.

Bile acid investigations were carried out in order to test the functional reabsorption capacities of the reservoir and its implications to the bile acid metabolism. A normal reabsorption of a radioactive labelled conjugated bile acid (SeHCAT) was found. Bile acid loss remained within normal limits and its composition consisted predominantly of primary free bile acids. Despite changes in the microbiological flora and the mucosal morphology of the reservoir, bile acid metabolism was normal.

Manometrical measurements of the continent ileostomy demonstrated a zone with increased pressure in the nipple valve. In rest as well as during increased intra-abdominal pressure, the nipple valve pressure remained higher than the reservoir pressure. Interviews with ten patients after they had obtained a continent ileostomy showed that whis operation had considerably improved their subjective psychic and social welfare, The feeling of freedom, because of having not to wear external appliances and the idea of being more 'normal' because of the ability to control the intestinal discharge was their greatest benefit. Although a heavy abdominal operation was required and some dietary restrictions remained, all but one patient preferred the continent ileostomy. In view of these results it would be advisable to take the continent ileostomy operation into consideration in all patients who are potential candidates for it. 


\section{SAMENVATTING EN CONCLUSIES}

Het continente ileostoma, dat in 1969 door Nils Kock werd geintroduceerd, bestaat uit een intra-abdominaal gelegen reservoir met afvoer, vervaardigd uit het laatste gedeelte van het ileum. Het reservoir wordt regelmatig geledigd met behulp van een catheter. Controle over dunne darm-inhoud en het overbodig zijn van stoma receptacula vergroten de levensvreugde van mensen met een ileostoma.

In 1982 werd met deze ingreep in het "De Wever" Ziekenhuis te Heerlen een begin gemaakt. Een verslag van de eerste 30 patiënten die een dergelijke operatie hebben ondergaan van januari 1982 tot oktober 1985 wordt in dit proefschrift gegeven.

Hoofdstuk 2 bevat een literatuuronderzoek over het conventionele ileostoma. Na lang experimenteren en ontwikkelen blijkt uiteindelijk het ileostoma volgens Brooke de gouden standaard te zijn.

De operatie-indicaties worden besproken en de belangrijkste complicaties, zoals de metabole en mechanische, worden vermeld. Ook wordt apart aandacht besteed aan de psychosociale gevolgen, welke bij ileostoma patiënten maar al te veel worden onderschat, terwijl deze juist de kwaliteit van hun leven in hoge mate bepalen.

Hoofdstuk 3 behandelt een aantal andere constructies van een ileostoma klep. Ook worden operaties besproken waarbij de anale sfincter wordt behouden, zoals de ileorectale en de ileoanale anastomose.

Hoofdstuk 4 beschrijft het continente ileostoma.

Theoretische beschouwingen van een lage druk reservoir, vervaardigd uit het distale ileum, worden geschetst. Verschillende afvoersystemen van het reservoir werden getest alvorens het klepmechanisme, vervaardigd uit een geinvagineerd gedeelte van de dunne darm, continentie voor dunne darm-inhoud garandeerde.

Aangezien desinvaginatie van de klep de belangrijkste complicatie bij de continent ileostoma operatie bleek, werden vele technieken ontwikkeld om invaginatie van de dunne darm te behouden.

Biologische gevolgen van deze ingreep zoals veranderingen in de bacteriële flora, slijmvliesmorfologie en darmresorptie worden nader besproken. Ook wordt aandacht besteed aan indicaties en contra-indicaties van deze ingreep. Bij bijna $95 \%$ van de patiënten werd continentie bereikt, alhoewel een hoog percentage heroperaties hiervoor noodzakelijk was. Het vooruitzicht op controle over dunne darm-inhoud en op overbodig zijn van stoma receptacula motiveerden patiënten tot het ondergaan van deze operatie(s).

Hoofdstuk 5 werkt een epidemiologische studie uit betreffende patiënten die in de periode van 1979 tot en met 1983 een conventioneel ileostoma hebben gekregen. Het aantal personen in Nederland met een ileostoma wordt op 4000 geschat. Hiervan komen er ongeveer 400 in aanmerking voor een continent ileostoma.

Hoofdstuk 6 beschrijft de eerste 30 patiënten (11 mannen en 19 vrouwen) dic in het "De Wever" Ziekenhuis een continent ileostoma hebben gekregen. Tevens worden de operatie indicaties daarvan aangegeven. De gangbare operatietechniek en postoperatieve verzorging worden gedetailleerd beschreven. Heroperatie was noodzakelijk bij 
13 van de 30 patiënten. Van deze 13 patiënten overleed 1 patiënt $1 e n$ gevolge van metastasen wan een rectum carcinoom an bestralingsenteritis en bij 2 patiënten werd het continente ileostoma verwijderd. Derhalve zijn 27 patiënten continent.

Zowel wan het conventionele ileostoma als wan het continente ileostoma werden de kosten geanalyseerd. Uit vergelijking bleek, dat conversie van een conventioneel naar een continent ileostoma een besparing van ongeveer $\mathbb{f} .45 .000$, per patiënt oplevert.

Hoofdstuk 7 belicht enkele aspecten van het continente ileostoma.

De biologische gevolgen van een ileum reservoir ten aanzien van de bacteriele flora, histologie van het slijmvlies en galzuur metabolisme werden bestudeerd. Daarnaast werden drukmetingen in het klepmechanisme en reservoir verricht. Met tien personen die een continent ileostoma hebben, werden vraaggesprekken gehouden om inzicht te verkrijgen in de invloed van dit stoma op hun psychisch en sociaal welbevinden.

Kwalitatieve en kwantitatieve bacteriekweken tonen aan dat de dunne darm-inhoud van het reservoir van een continent ileostoma een tien-voudig aantal microorganismen per milliliter bevat in vergelijking tot de dunne darm-inhoud van een conventioneel ileostoma. Bij continent ileostoma patiënten werd een significant groter aantal anaerobe microorganismen gekweekt. Dit duidt op een meer colon-achtige bacterie flora.

Morfologisch onderzoek van het slijmvlies van het reservoir toont een verandering van de villus/crypte verhouding in vergelijking tot normaal illeum slijmvlies. De villi worden korter en knotsvormig, terwijl de crypten langer worden. Reactieve veranderingen worden bij lichtmicroscopisch onderzoek waargenomen. Het verschijnen van sulfomucine producerende cellen en slijmbeker cellen hyperplasie wijzen op een colon-achtige verandering van het slijmvlies in het reservoir. De endocrine cellen populatie blijkt niev veranderd te zijn in vergelijking met normaal ileum slijmvlies. Precancereuze veranderingen worden niet gesignaleerd. Een galzuur onderzoek wordt verricht om de functionele resorptie capaciteit van het reservoir en de mogelijke invloed op het galzuur metabolisme te meten. Normale resorptie van een radioactief gemerkt geconjugeerd galzuur (SeHCAT) wordt vastgesteld. Het galzuur verlies van continent ileostoma patiënten blijkt normaal te zijn. De samenstelling van de uitgescheiden galzuren bestaat voornamelijk uit primaire ongeconjugeerde galzuren.

Ondanks veranderingen van de microbiële flora en de morfologie van het slijmvlies van het continent ileostoma reservoir is een normaal galzuur metabolisme vastgesteld.

Drukmetingen van het continente ileostoma tonen in het klepmechanisme een zone met verhoogde druk ten opzichte van het reservoir.

Zowel in rust als tijdens verhoogde abdominale druk blijft de druk in de klep hoger dan die in het reservoir.

Uit interviews met een 10-tal patiënten met een continent ileostoma bleek dat dit stoma hun subjectief psychisch en sociaal welbevinden aanmerkelijk had verbeterd. Het overbodig zijn van stoma receptacula en het gevoel een 'normaler' leven te kunnen leiden vanwege het onder controle hebben van ontlasting werden als de belangrijkste voordelen ervaren. Hoewel een ingrijpende abdominale operatie hiervoor noodzakelijk was en bepaalde voedselbeperkingen bleven, gaven alle patiënten, op één na, de voorkeur aan het continente ileostoma.

Gezien de bovengenoemde resultaten verdient het aanbeveling deze operatie in overweging te geven aan alle patiënten die in aanmerking komen voor het continente ileostoma. 


\section{REFERENCES}

1. Akovbiantz A. Kontinenzerhaltende Operationen bei Colitis ulcerosa. Helv. Chir. Acta 1982 ; 48 : $789-796$

2. Andersson H, Fasth S, Fillipsson S, et al. Faecal excretion of intravenously injected ${ }^{4} \mathrm{C}$-Cholic acid in patients with comventional ileostomy and in patients with continent ileostomy reservoir. Scand. J. Gastroenterol. 1979:14:551-554

3. Aylett $S O$. Three hundred cases of diffuse ulcerative colitis treated by total colectomy and ileo-rectal anastomosis. Br. Med. J. 1966; 1 : 1001-1005

4. Baker WNW, Glass RE, Ritchie JK, Aylett SO. Cancer of the rectum following colectony and ileorectal anastomosis for ulcerative colitis. Br. J. Surg. $1978 ; 65: 862-868$

5. Barnett WO. Continent ileostomy. South Med. J. 1983; $76: 583-586$

6. Baum WG. Resection eines carcinomatosen Dickdarmstuckes. Centralblat fur Chirurgie $1879 ; 6$ : $167-176$.

7. Beatrs $\mathrm{OH}$. Use of ileal reservoir following proctocolectomy. Surg. Gynecol. Obstet. $1975 ; 141$ : 363-366

8. Beahrs OH. Present status of the continent ileostomy: ileal reservoir with ileostomy rather than ileostomy alone. Dis. Colon Rectum 1976; 19:192-194

9. Berglund B, Kock NG, Myrwold HE. Volume capacity and pressure characteristics of the continent ileostomy reservoir. Scand. J. Gastroenterol. $1984 ; 19: 683-690$

10. Berglund B, Asztely M, Kock NG, Myrvold HE. Reflux from the continent ileostony reservoir: a radiologic evaluation combined with ;pressure recording. Dis. Colon Rectum $1985 ; 28: 502-505$

11. Bloom RJ, Larsen CP, Watt R, Oberhelman Jr. HA. A Rexppraisal of the Kock continent illeostomy in patients with Crohn's disense. Surg. Gynecoll. Obstet. 1986;162:105-108.

12. Bokey EL, Dent OF, Zubrzycki J, Chapuis PH, Dunn DW. Surgical morbidity after ileostomy in New South Wales. Med. J. Aust. $1984 ; 141: 494-495$

13. Bokey EL, Hayward PG, Chapuis PH, Johnson SE. Mechanism and prevention of nipple valve. dessusception: an;experimental study. Aust. N.Z. J. Surg. $1984 ; 54: 77-80$

14. Bonello JC, Thow GB, Manson RR. Mucosal enteritis: a complication of the continent ileostomy. Dis. Colon Rectum $1981 ; 24: 37-41$

15. Borriello SP. Bacteria and gastrointestinal secretion and motility. Scand. J. Gastroenterol 1984; 19 (suppl. 93) : 115-121

16. Brandberg A, Kock NG, Philipson BM. Bacterial flora in intraabdominal ileostomy reservoir: a study of 23 patients provided with "continent ileostomy". Gastroenterol. $1972 ; 63: 413 \times 416$

17. Brooke BN. The management of an ileostomy including its complications. The Lance $1952 ; 2: 1102 * 104$

18. Brooke BN, Jetter KF, Todd IP. Stomas Clin. Gastroenterol. $1982 ; 11$ : 235-435

19. Bronillette JN, Pryor E, Fox Jr. TA. Evaluation of sexual dysfunction in the female following rectal resection and intestinal-stoma. Dis. Colon Rectum 1981; $24: 96-102$

20. Brown JY. Value of complete physiological rest of latrge bowel in treatment of cervain ulcerations and obstructive lesions of this organ. Surg. Gynecol. Obstet. 1913;16:601

21. Buchmann P, Weterman IT, Keighley MRB, Pena SA, Allan RN, Alexander-Willams J. The prognosis of ileorectal anastomosis in Crohn"s (disease. Br. J. Surg. 1981;68:7-10

22. Burink van-Withaar AGJ. Problematiek van stomapatienten. De Psycholoog 1984 ; XIXC: $482-490$

23. Burnham WR, Lennard-Jones JE, Brooke BN. Sexual problems among married ileostomists. Gut $1977 ; 18: 673-677$

24. Chandter JG, Adams RB, Friedman CJ, Marcella KL, Guerrant RL. Assessment of an implantable: illeostomy sphincter. Surgery $1985 ; 98: 72-80$

25. Clarke AM, Hill GL, Macbeth WAAG. Intestinal adaptation to salt depletion in a pationt with an ileostomy. Gastroenterol. $1967 ; 53: 444-449$

26. Cohen Z. Evolution of the Kock Continent Reservoir lleostomy. Can. J. Surg. $1982 ; 25: 509-513$

27. Conwatecesquibb: Personal Communication

28. Cranley B, McKelvey STD. The Kock ileostomy reservoir : an experimental study of mathods of improving valve stability and competence. Br. J. Surg. $1981 ; 68: 545-550$

29. Cranley $B$. The Kock reservoir ileostomy:a review of its development, problems and role in modem surgical practice. Br. J. Surg. 1983; 70:94-99

30. Cranley B, McKelvey STD. lleal reserwoirs: an experimental study of motility in the Kock and triplicated pelvic illal pouches. J. Surg. Res. $1983 ; 34: 279-285$ 
31. Crile Jr. G, Turnbull fr. RB. The mechanism and prevention of ileostomy dysfunction. Anm. Surg. $1954 ; 140: 459-466$

32. Delhez H, Berg JW wan den, Blankenstein M van, Meerwaldt JH. New method for the determination of bile acid tumover tssing SeH T. Eur J. Nucl Med. 1982;7:269-271

33. Dozois RR. Kelly KA, Beart Jr. RW. Beahrs OH Improved results with continent ileostomy. Ann. Surg. $1980: 192: 319-324$

34. Dozois RR, Kelly KA, Ilstrup D, Beart Jr. RW, Beahrs OH. Factors affecting revision rate after continent ileostomy. A.rch. Surg. $1981 ; 116: 610-613$

35. Dozois RR. Ileal 'J' pouch-anal anastomosis. Br. J. Surg. $1985 ; 72$ (suppl.) : 80-82

36. Dozois RR, Kelly KA, Beart Jr. RW, Beahrs OH, Continent ileostomy: the Mayo Clinic experience. In: Dozois RR. Alternatives to conventional ileostomy. Chicago: Year Book Medicall Publishers, 1985 ; $180-198$

37. Dragstedt LR, Dack GM, Kirsner JB. Chronic ulcerative colitis, A summary of evidence implicating bacterium necrophorum as an etiologic agent. Ann. Surg. 1941;114:653-662

38. Ein SH. Five years of the pediatric Kock pouch. J. Pediatr. Surg $1982 ; 17 ; 644-652$

39. Ekman $\mathrm{H}$, Jacobsson $\mathrm{B}$, Kock $\mathrm{NG}$, Sundia $\mathrm{T}$. The functional behavior of different types of intestinal urine bladder substitutes. Congr. Soc. Int. Urol. $1964 ; 11: 213$

40. Eyk-Althoff van G: Personal Communication

41. Fagan EA, Chadwick VS, Baird IM. SeHCAT absorption: a simple test of ileal function. Digestion $1983 ; 26: 159-165$.

42. Failes DG, Killingback $M$, Stuart $M$, De Luca $C$, Riley C. lleostomy reconstruction. Aust. N.Z. J. Surg. $1979 ; 49: 340-344$

43. Failes DG. The continent ileostomy : an 11 year experience. Aust. N.Z. J. Surg $1984 ; 54: 345-352$

44. Fasth $S$, Oresland $T$, Ahren $C$, Hulten L. Mucosal proctectomy and ileostomy as an alternative to conventional proctectomy. Dis. Colon Rectum 1985:28:31-34

45. Fendel $\mathrm{EH}$, Fazio VW. Construction of a continent ileostomy using a porcine aortic valve: a preliminary report. Dis. Colon Rectum $1982 ; 25: 21-23$

46. Finegold SM, Sutter VL, Boyle JD, Shimada K. The normal flora of ileostomy and transwerse colostomy effluents. J. Infect. Dis. 1970; 122:376-381

47. Gadacz TR, Kelly KA, Phillips SF. The continent illeal pouch: absorptive and motor features. Gastroenterol. $1977 ; 72: 1287-1291$

48. Gallagher ND, Harrison DD, Skyring AP. Fluid and electrolyte disturbances in patients with longestablished illeostomies. Gut $1962 ; 3: 219-223$

49. Gelernt IM. Experience with the continent illeostomy. Mt. Sinai J. Med. $1983 ; 50: 156-160$

50. Gerber A, Apt MK, Craig PH. The Kock continent ileostomy. Surg. Gynecol. Obstet. 1983 ; 156 : 345-350

51. Gerber A, Apt MK, Craig PH. The improved quality of life with the Kock continent ileostony. I. Clin. Gastroenterol. 1984;6:513-517

52. Glocckner MR, Starling JR. Providing sexual information to ostomy patients. Dis. Colon Rectum 1982 ; $25: 575-579$

53. Goldblatt MS, Corman ML, Haggitt RC, Coller JA, Veidenheimer MC. Ileostomy complications requiring revision the Lahey Clinic experience 21964-1973. Dis. Colon Rectum 1977; 20:209-214

54. Golden HK. Psychiatric casualties following revision to the "continent" Kock ileostomy. Am. J. Dig. Dis. $1976 ; 21: 969-973$

55. Goldman SL, Rombeau JL. The continent ileostony: a collective review. Dis. Colon Rectum 1978; $21: 594-599$

56. Goligher JC. Ileostomy reconstruction. Br. J. Surg. 1963; $50: 259-266$

57. Golighter JC, Lintott D. Experience with 26 reservoir ileostomies. Br. J. Surg. 1975;62:893-900

58. Goligher JC. Procedures conserving continence in the surgical management of ulcerative colitis. Surg. Clin. North Am. $1983 ; 63: 49-60$

59. Gorbach SL, Nahas L, Weinstein L, Levitan R, Patterson JF. Studies of intestinal microflora. The microflora of ileostomy effluent: a unique microbial ecology. Gastroenterol. $1967 ; 53: 874-880$

60. Grundest SF, Fazio $\mathrm{V}$, Weiss RA, et al. The risk of cancer following colectomy and ileorectal anastomosis fior extensive mucosal ulcerative colitis. Anm. Surg. 1981;193:9-14

61. Guyton AC. Textbook of medical physiology. 6th ed. Philladelphia: W.B. Saunders Company, 1981.

62. Halvorsen JF, Heimann. P, Hoel R, Nygaard $\mathrm{K}$. The continent reservoir ileostomy: Review of a collective series of thirty-six patients form three surgical departments. Surgery $1978 ; 83: 252-258$

63. Handelsman JC, Fishbein RH. Permanent illeostomy without external appliance : Kock internal reservoir (pouch) operation. Johns Hopkins Med. J. 1976; 138: 161-166 
64. Heppell J, Kelly KA. Philips SF, Beart Ir. RW, Teldnder RL Perralt J. Physiologic aspects of continence after colectomy, mucosal proctectomy, and endorectal iloo-sanal mastomosis. Ann. Surg. $1982 ; 195: 435-443$

65. Hill GL, Mar WSJ, Goligher JC. Gallstones after ileostomy and ileal resection. Gut 1975:16:932.936

66. Hofmann AF. Chemistry and enterohepatic circulation of bile acids. Hepatology $1984:$ : (suppl.):4-14

67. Hulten L. Kewenter J, Persson $E$, Ahren $C$. Vitamin $B_{02}$ absomption in ileostomy patients after operation for ulcerative colitis. Scand. I. Gastroenterol. 1970; 5:113-116

68. Hulten L, Fasth S. Loop ileostomy for protection of the newly constructed ileostomy neservoir. Br. I. Surg. $1981 ; 68: 11-13$

69. Hulten L, Svaninger $G$. Facts about the Kock continent ileostomy. Dis. Colon Rectum 1984; 27 : $533-557$

70. Jagelman $\mathrm{DG}$, Lewis $\mathrm{CB}$, Rowe-Jones DC. Ileorectal anastomosis: appreciation by patients. Br. Med. J. $1969 ; 1: 756-757$

71. Jagenburg R, Dotevall G, Kewenter J, Kock NG, Philipson BM. Absorption studies in patients with "intra-abdominal ileostomy reservoirs" and in patients with conventional ileostomies. Gut $1971 ; 12$ : $437-441$

72. Jagenburg $\mathbf{R}$, Kock $N G$, Philipson BM. Vitamin $\mathbf{B}_{12}$ absorption in patients with continent ileostomy. Scand. J. Gastroenterol. $1975 ; 10: 141-144$

73. Kay RM, Cohen Z, Siu KP, Petrunka CN, Strasberg SM. Neal excretion and bacterial modification of: bile acids and cholesterol in patients with continent ileostomy. Gut $1980 ; 21: 128-132$

74. Kelly DG, Branon ME, Phillips SF, Kelly KA. Diarthoes after continent ileostomy. Gut 1980;21: $711-716$

75. Kelly DG, Phillips SF, Kelly KA, Weinstein WM, Gilchrist MJR. Dysfunction of the continent ileostomy: clinical features and bacteriology. Gut $1983 ; 24: 193-201$

76. Kelly KA, Heerden JA van, Beart Jr. RW, Pemberton JH. The continent ostomy valve : early clinical results. In: Dozois RR: Alternatives to conventional ileostony. Chicago: Year Book Medical Publishers, $1985 ; 226-251$

77. Kennedy HJ, Lee $G$, Claridge $G$, Truelove $\mathrm{SC}$. "The heath of subjects living with aermanent ileostomy. O. J. Med. $1982 ; 51: 341-357$

78. Kennedy $\mathrm{HJ}$, Al-Dujaili EAS, Edwards CRW, Truelove SC. Water and electrolyte ballatnce un subjects with a permanent ileostomy. Gut $1983 ; 24: 702-705$

79. Kennedy HJ, Compston J, Heynen G, et al. Calcium metabolism in subjects living with a permanent ileostomy. Digestion $1983 ; 26: 131 \sim 136$

80. Kewenter J. Ahlman H, Hulten L. Cancer risk in extensive ulcerative colitis. Ann. Surg. 1978; 188 : $824-828$

81. King SA. Quality of life: the continent ileostomy. Ann. Surg. $1975 ; 182: 29-32$

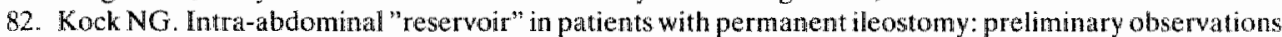
on a procedure resulting in fecal continence in five ileostomy patients. Arch. Surg. 1969; 99:223-231

83. Kock NG. Ileostomy without extemal appliances: a survey of 25 patients provided with intra-abdominal intestinal reserwoir. Ann. Surg. 1971 ; 173:545-550

84. Kock NG. Continent Ileostomy. Prog: Surg. $1973 ; 12: 180.201$

85. Kock NG. Present status of the continent ileostomy: surgical revision of the malfunctioning bleostony. Dis. Colon Rectum: $1976 ; 19: 200-206$

86. Kock NG, Darle N, Hulten L, Kewenter \#, Myrvold HE, Philipson BM. Ileostomy. Curr. Probl, Surg. $1977 ; 14: 1-52$

87. Kock NG, Myrold HE, Nisson LO. Progress report on the continent ileostomy. World J. Sutg. 1980 :4:143-148

88. Kock NG, Myrvold HE, Nisson LO, Ahren C. Construction of a stable nipple valwe for the continent ileostomy. Anm. Chir Gynecol. 1980;69:132-143

89. Kock NG, Myrvold HE, Nitsson LO, Philipson BM. Continent ileostorny. Acta Chir. Scand. 1981 ; $147: 67-72$

90. Kock NG, Myrold HE, Nilsson LO, Philipson BM. Continent ileostomy : the Swedishexperience. In: Dozois RR.: Alternatives to conwentional ileostomy. Chicago: Year Book Medical Publishers, 1985 ; 163-179

91. Kock NG, Myrwold HE, Nisson $\mathrm{LO}$, Phipson BM. Achtzehn Juhre Erfahrung mit der kontinenten Heostomie. Chirurg $1985 ; 56: 299-304$

92. Kock NG, Myrvold HE, Philipson BM, Svaninger G, Ojerskog B. Continent cecostomy: an account of 30 patients Dis. Colon Recturm $1985 ; 28: 705-708$.

93. Kock NG. Personal Communication. 
94. Kubben FIM, Assche CLMVJ van, Bosman FT. FMRF-amide immunoreactivity in the mammallan gastroenteropancreatic neurownocrine system. Histochemistry 1986 : in press

95. Kurchin A, Ray JE, Bluth EI, et al. Cholelithiasis in lleostomy patients. Dis. Colon Rectum 1984;27 : 585.588

96. Lahey FH. The advantages of a stab wound ileostomy, Surg. Gynecol. Obstet. 1952:95:28

97. Loeschke $K$, Bolkert $T$, Kiefhaber $P$, et al. Bacterial overgrowth in ileal reserwoirs (Kock Ponch): extended functional studies. Hepato-Gastroenterol. $1980 ; 27: 310 \mathrm{~m} 16$

98. Loygue J, Salmon R, Amatd PS, Levy E. Lileostomie continente: experience de 17 cas. Chirurgie $1978 ; 104: 512-517$

99. Lubbers EJC, Brendan Dewlin H. The complications of permanent ileostomy. Poster C.I.C.D., 8th World congress, Ansterdan 1984

100. Madigary MR. The continent illeostomy and the isolated ileal bladder. Ann. R. Coll. Surg. Engl. 1976 ; $58: 62-69$

101. Mashige $\mathrm{F}$, Imai $\mathrm{K}$, Osuga T. A simple and sensitive assay of total serum bile acids. Clin. Chim. Acta $1976 ; 70: 79-86$

102. McLeod RS, Fazio WW. Quality of life with the continentiteostomy. World J. Surg. 1984;8:90-95

103. McLeod RS, Lavery IC, Leatherman JR, et al. Patient evaluation of the conventional ileostomy. Dis. Colon Rectum 1985;28:152-154

104. Meijer DW, Linschoten $H$, Klopper PJ. The construction of a continent illeostomy. Poster C.l.C.D., 8 th World comgress, Amsterdam 1984

105. Merrick MV, Eastwood MA, Anderson JR, Ross HM. Enterohepatic circulation in man of a gammaemitting bile-acid conjugate, 23-Selena-25-Homotauro cholic acid (SeHCAT) : J. Nucl. Med. 1982 ; $23: 126-130$

106. Mihranian MH, Miller DR. Continent ileostomy in dogs. An experimental study of ileal pouches using a simple prosthetic valve. J. Surg. Res. $1981 ; 31: 69-76$

107. Montagne JP, Kressel HY, Moss AA, Schrock TR. Radiologic evaluation of the continent (Kock) ileostomy. Radiology $1978 ; 127: 325-329$

108. Moore JB. Mechanical small bowel obstruction. In: Eiseman B. Prognosis of surgical disease. Philadelphia : W.B.Saunders Company, $1980 ; 274-276$

109. Morowitz DA, Kirsmer JB. lleostomy in ullcerative colitis: a questionnaire study of 1,803 patients. Am. J. Surg. $1981 ; 141: 370-375$

110. Myrwold HE, Jonsson KO. Pressure profiles in ileal pouch outlets. Scand. J. Gastroenterol. $1979 ; 14$ : 753-759

111. Nicholls RJ, Moskowitz RL, Shepherd NA. Restoratiwe proctocolectomy with ileal reservoir. Br. J. Surg. $1985 ; 72$ (suppl.) : $76-79$

112. Nilsson LO, Andersson H, Hulten L, et al. Absorption studies in patients six to 10 years after construction of illeostomy reservoirs. Gut $1979 ; 20: 499-503$

113. Nilsson LO, Kock NG, Kylberg F, Myrvold HE, Panselius I. Sextual adjustment in ileostomy patients before and after conwersion to continent ileostomy. In: Nilsson LO. The continent ileostomy, Goteborg $1980 ; 65 \times 72$

114. Nilsson LO, Kock NG, Lindgren 1. Myrvold HE, Philipson BM, Ahren C. Morphological and histochemical changes in the mucosa of the comtinent ileostomy reservoir 6 m 10 years after its reconstruction. In: Nilsson LO. The continent illeostomy, Goteborg 1980;29-39

115. Nilsson 1.O. Myrvold HE, Swolin B, Ojerskog B. Vitamin B-12 in Plasma in patients with continent ileostomy and long observation time. Scand.J. Gastroenterol. 1984; 19:369-374

116. Nilsson LO, Andersson H, Bosaeus I, Ojerskog B. Total body water and total body potassium in putients with conventional or continent ileostomies. Poster C.I.C.D., 8th World congress, Amsterdam 1984

117. Oakley JR, Jagelman DG, Fazio VW, et al. Complications and quality of life after ileorectal anastomosis for ulcerative colitis. Am. J. Surg. $1985 ; 149: 23-30$

118. Orangio GR, Bronsther $B$. Abrams M, Wise $L$. A new type of continent ileostomy: results of an animal study. Dis. Colon Rectum $1984 ; 27: 238-243$

119. Osuga T, Mitumura K, Mashige F, Imä K. Evaluation of fhuorimetrically estimated serum bile acid in liver disease. Clin. Chim. Acta 1977; $75: 81-90$.

120. Palmu A, Sivula A. Kock"s continent ileostomy: results of 51 operations and experiences with correction of nipple-valve insufficiency. Br. J. Surg. $1978 ; 65 ; 645-648$

121. Parc R, Levy E, Frileux $\mathbf{P}$, Loygue J. Current results: lleorectal anastomosis after total abdomunal colectomy, In: Dozous RR. Alternatives to conventional ileostomy. Chicago : Year Book Medical Publishers, $1985 ; 811-99$ 
122. Parks AG, Nicholls RJ. Proctocolectorny without ileostomy for ulcerative colitis. Br. Med. j. 1978 : 2 :85-88

123. Parks AG, Nicholls RJ, Belliveau P. Proctocolectomy with ileal reserwoir atnd anal anastomosis. Br. J Surg. $1980 ; 67: 533-538$

124. Pemberton JH, Kelly KA. Phillips SF. Achiewing ileostomy continence with an indwelling stomal device. Surgery $1981 ; 90: 336-343$

125. Pemberton JH, Dozois RR. The continent ileostomy. Probl. Gen. Surg. 1984; $1: 27-38$

126. Philipson B, Brandberg A, Jagenburg R, Kock NG, Lager I, Ahren C. Mucosal morphology , bacteriology, and absorption in intra-abdominal ileostomy reservoir. Scand. J. Gastroenterol. $1975 ; 10: 1-9$

127. Philipson BM, Kock NG, Robinson JWL, Menge H, Mirkovitch V. Function and structure of the mucosa of continent ileostomy reservoirs in dogs. Gut $1975 ; 16: 132-136$

128. Ravitch MM, Sabiston Jr. DC. Anal ileostony with preservarion of the sphincter. Surg. Gynecol. Obstet. $1947 ; 84: 1095-1099$.

129. Ritchie JK. Ileostomy and excisional surgery for chronic inflammatory disease of the colon; a survey of one hospital region. Gut $1971 ; 12: 528-540$

130. Roberts JW. Continent ileostomy. Surg. Clin. North Am. $1979 ; 59: 853-862$

131. Rolstad BS, Wilson G, Rothenberger DA. Sexual concerns in the patient with an ileostony. Dis. Colon Rectum 1983;26:170-171

132. Roy PH, Sauer WG, Beahrs OH, Farrow GM. Experience with ileostomies: evaluation of long-term rehabilitation in 497 patients. Am. J. Surg. $1970 ; 119: 77-86$

133. Sanada $Y$, Fonkalsrud EW, Kojima Y. Intermittent ileostomy occlusion for fecal storage using balloon catheter. Surgery $1982 ; 91: 459-466$

134. Sauberli H, Akovbiantz A, Hahnloser P. Die kontinente lleostomie; Indikation und Resultate. Zbl. Chirurgie $1982 ; 107: 1228-1236$

135. Schjonsby H, Halvorsen JF, Hofstad T, Hovdenak N. Stagnant loop syndrome in patients with continent ileostony (intra-abdominal ileal reservoir). Gut 1977;18:795-799

136. Schmidt E. Sphincteroplasty using autologous smooth muscle. In: Heberer G., Denecke $\mathrm{H}_{\text {: }}$ Colorectal surgery. Berlin : Springer Verlag, $1982: 67-71$.

137. Schrock TR. Complications of continent ileostomy. Am. J. Surg. $1979 ; 1.38: 162-169$

138. SMR Jaarboek 1983 ; Landelijke Medische Registratie. Uitgave : S.J.G. 1983

139. Soundy PG, Simpson JP, Ross HM, Merrick MV. Absorbed dose to man from the Se-75 labeled conjugated bile salt SeHCAT. I. Nucl. Med. 1982; 23: 157-16!

140. Spicer SS. Diamine methods for differentiating mucosubstances histochemically. J. Histochen. Cytochem. $1982 ; 13: 211-234$

141. Standertskjold-Nordenstam CG, Palmu A, Sivula A. Radiological assessment of nipple-valve insufficiency in Kock's continent reservoir ileostomy. Br. J. Surg. $1979 ; 66: 269-272$

142. Starrenburg AJM. Electrostimulation of the terminal ileum by means of a carbon fibre electrode. Rotterdam : Erasmus Universiteit, 1985. 158pp. Thesis.

143. Steichen FM. The creation of autologous substitute organs with stapling instruments. Am. I. Surg. $1977 ; 134: 659-673$

144. Stern H, Cohen Z, Wilson DR, Mickle DAG. Urolithiasis risk factors in continent reserwoir ileostomy patients. Dis. Colon Rectum 1980; $23: 556-558$

145. Telander RL., Perrault I. Colectomy with rectal mucosectomy and hleoanal anastomosis in young patients. Arch. Surg. $1981 ; 1.16: 623-629$

146. Thompson JS, Williams SM. Fistula following continent ileostomy. Dis. Colon Rectum 1984:27: $193-195$

147. Turnbull Jr. RB. Management of the ileostomy. Am. J. Surg. 1953;86:617-624

148. Uding HGA. Rapport stoma polikliniek: Personal Conmunication

149. Utsunomiya J, Iwama $T$, Imajo $M$, et al Total colectomy, mucosal proctectomy and ileoanal anastomow sis. Dis. Colon Rectum 1980; $23: 459-466$

150. Utsunomiya $J$, Iwama $T$. The $J$ ileal pouch-anal anastomosis : the Japanese experience, In: Dozos R.R.: Alternatiwes to conwentional Cileostony. Chicago: Year Book Medical Publishers, 1985 : $371-383$

151. Valkamo E. Ileostomy in ulcerative colitis: a long term study of the results of conventional and continent ileostomy in 161 patients. (Ann. Chir. Gynecol. 1981;195:1-81

152. Veidentheimer MC, Dailey TH, Meissner WA. Ileorectal anastomosis for inflammatory disease of the large bowel. Am. I. Surg. $1970 ; 119: 375-378$

153. Verheesen PE, Brombacher PJ. Een eenvoudige gaschromatografische analyse van gallzuren in gal. Tijdschr.Ned.Ver.Klin.Chem. 1980; $5: 133-134$ 
154. Warner KE, Luce BR. Cost-benefit and cost-effectiveness analysis in health care. Principles, practice and potential. Michigan: Health administration press, $1982 ; 93.98$.

155. Warren $\mathrm{R}$, McKittrick LS. Ileostomy for ulcerative colitis: technique, complications and management. Surg. Gynecol. Obstet. 1951:93:555-567

156. Weinstein M, Rubin RJ, Salwati EP. Detachment of the continem ileostomy pouch from the anterior abdominal wall: report of two unusual cases. Dis. Colon Rectum 1976; $19: 705-706$

157. Whates PD, Irwing M. Return to work following ileostomy. Br. J. Surg. 1984; $71: 619-622$

158. Wolfstein IH, Bat L, Neumann G. Regeneration of rectal mucosa and recurrent polyposis coli after total collectomy and ileoanal anastomosis. Arch. Surg. 1982;117:1241-1242

159. Wong WD, Rothenberger DA, Goldberg SM. lleoanal pouch procedures. Curr. Probl. Surg. 1985; $22: 1-55$ 


\section{ACKNOWLEDGEMENTS}

This thesis could not have been completed without the enthusiasm and contributions of many others. Although it is impossible to thank everyone personally for their considerable support and assistance. 1 would like to take the opportunity of expressing my gratitude to those without whose help this thesis would never have been written.

Prof. Dr N.G. Kock: I consider you as my guest of honour on this occasion. Your name will always be associated with the continent ileostomy operation, as you are the inventor and advocate the procedure which has been followed worldwide. You taught us about the continent ileostomy operation and stimulated our interest in its surgical physiology which became the foundation of this thesis.

Dr J. Lens: Since you introduced the continent ileostomy operation in the Netherlands, many patients have benefitted from this procedure. Your great enthusiasm and constructive criticism were of invaluable help to me in preparing this manuscript.

Prof. Dr J M. Greep: You smoothed the way for this thesis in your characteristically dynamic manner. I am very grateful for your critical views

Prof. Dr F.T. Bosman: It was during my time as a student-assistant working in your laboratory years ago that I first developed a passion for scientific work. It was your enthusiasm and the vitality of your work that inspired me most. Once again I would likke to thank you for your help in preparing this thesis.

Prof. Dr P.J. Brombacher: Your specialism has had a great influence on this thesis. I am very grateful for having received your whole-hearted support and essential assistance with the investigations to realise this thesis.

Prof. Dr G.N.J. Tytgat: You were connected with the subject in a special way. Your ideas and judgement have contributed much to enhancing the quality of this work.

Al1 recorded conventional and continent ileostomy patients: without your help this study could never have been effected.

- The surgeons of the "De Wever" Hospital (head: Dr J.D.K. Munting) and residents of the surgical department for their support in completing this thesis.

- All the staff of the "De Wever" Hospital that have been involved, and in particular the Day-admission. (head: W.I.J.M. Hendricks), the Out-patient Operating Theatre (head: A.F.W. Verluyten), the Outpatient Department (head: P.L.G. Lenoire), the Clinical Chemistry Laboratory (head: Prof. Dr P.J. Brombacher), the Medical Microbiological Laboratory (head: Dr B.I. Davies), the Isotope Laboratory (head: Dr A.H.J. Gijzen), where Ch. de Waal especially did a lot of work, the Deptartment of Nuclear Medicine (head: drs A.I.A. Rahmy), the Department of Pathology (head: Dr R.G.J. Willighagen), Medical Registration (head: N.P.L.van der Molen) and the library (head: Mrs R.A.M.P Clignet-

Quaedvlieg).

- Mrs drs A.G.M. van Burink-Withaar for her support on the psychological aspects of this study, Mrs. W. den Esch-Janssen, for conducting and summarizing the interviews and Prof. Dr J.J.C. B. Bremer for his constructive criticism on this subject.

- Mrs Dr M.P. wan Dieijen-Visser for her support in the bile acid analysis together with P. E. Verbecsen.

- Prof. Dr P.G. Knipschild for his contribution to the epidemiological survey.

- Prof. DrF.F.H. Rutten and drs A.J.H.A. Ament for their help with the cost analysis.

- Mrs. C.L.M.V.J. Hermans-van Assche for preparing the histological sections.

- G.W.M.L.J. Reumkens for his assistance with the manometry.

- H.J.W. Willers and F. Goutier for the photography.

- C. Voskamp for the illustrations and cover design.

- Mrs drs C.F.P.M. Gohres-van der Wolf, who transformed my translated Dutch into English.

Financial support for this thesis was given by the research funds of the "De Wever" Hospital, the "Stichting Dr Ir J.H.I. van de Laar", the surgeons of the "De Wever" Hospital, Convatec-Squibb, Smith Kline ty French and Amersham Nederland. 
It hold the deepest respect for the way in which my parents have encouraged and motivated us, their children, Io achieve our endeavours.

Finally, Ithank my wife, Denise, for her all-round support and understanding which I have been fortunate enough to be able to take for granted.

\section{CURRICULUM VITAE}

The atthor was born in Groningen, The Netherlands on 22 nd January 1956.

He attended Grammar School (sciences section) (gymnasium B) in Leiden and passed his final examination in 1974. He attended the University of Leiden and graduated with a medical degree in February 1982 . He started his surgical residency at the Surgical Department (Head Dr J.D.K. Munting) in "De Wever" Hospital, Heerlen and will be registered as a general surgeon in July 1988. 